\title{
Also BSS102
}

NBSIR 76-1082

\section{A Survey of State Legislation Relating to Solar Energy}

Robert M. Eisenhard

Office of Building Standards and Codes Services and

Office of Housing and Building Technology

Center for Building Technology

Institute for Applied Technology

National Bureau of Standards

Washington, D. C. 20234

April 1976

Prepared for

Energy Research and Development Administration

Division of Solar Energy

Washington, D. C. 20545

and

Department of Housing and Urban Development Division of Energy. Building Technology and Standards

Washington, D. C. 20410 



\section{A SURVEY OF STATE LEGISLATION RELATING TO SOLAR ENERGY}

Robert M. Eisenhard

Office of Building Standards and Codes Services and Office of Housing and Building Technology

Center for Building Technology Institute for Applied Technology National Bureau of Standards

Washington, D. C. 20234

April 1976

Prepared for

Energy Research and Development Administration

Division of Solar Energy

Washington, D. C. 20545

and

Department of Housing and Urban Development

Division of Energy, Building Technology and Standards

Washington, D. C. 20410

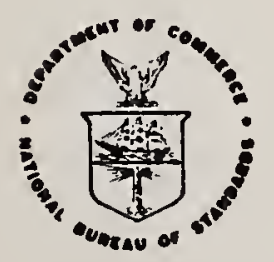

U.S. DEPARTMENT OF COMMERCE, Elliot L. Richardson, Secretany

Dr. Botey Ancher-datmaon. Aschtemt Scarotary for Scionce and Tochnology 

Abstract

This report reviews enacted State legislation dealing with solar energy. Acts involving tax incentives, reduced property assessments, research and development, solar easements and solar energy promotion are identified and abstracted. The responsible State agency and official are listed. Acts and supporting forms and other information are included as appendices.

Keywords: Architecture; buildings; design; energy; legislation; solar; State 
Abstract . . . . . . . . . . . . . . . . . $i i$

1. Introduction . . . . . . . . . . . . . . . . 1

2. Overview . . . . . . . . . . . . . . . . 2

3. State Legislation Review . . . . . . . . . . . 3

Figure 1 States with Acts Providing Property Tax Incentives for Use of Solar Energy in Buildings . . . . . . 5

Figure 2 States with Acts Providing for Income or Sales Tax Incentives for Use of Solar Energy and Other Solar Considerations . . . . . . . . . . . . . 6

Figure 3 States with Acts Providing Support of Research, Development, Promotion, or Investigation of Solar Energy . . . . . . . . . . . . . . 7

Bibliography . . . . . . . . . . . . . . . . . 41 Appendix . . . . . . . . . . . . . . . . . . 43
A State Forms, Instructions, Data
B State Legislation 
The Energy Reorganization Act of $1974,1 /$ which created the Energy Research and Development Administration (ERDA), states "The responsibilities of the Administrator 2.7 shall include.. . encouraging and conducting research and development including demonstration of commercial feasibility and practical applications of . . . solar . . . energy sources," and ". . . encouraging and conducting research and development in clean and renewable energy sources." The National Program for Solar Heating and Cooling, $3 /$ developed by an Interagency Task Force chaired by the Energy Research and Development Administration and responsive to the public laws passed by the Congress, $4 /$ recognizes that the "increased first costs of solar heating and cooling equipment may result in increased assessments and higher taxes." It also notes that "public policy . . may wish to encourage the use of solar energy to reduce the need for other fuels." In 1974 and 1975, many States introduced bills dealing with various phases of solar energy activity as it relateds to buildings. 5 / These bills included tax incentives, building codes, easements and zoning, and State funding of research, development and promotional activities. The National Program for Solar Heating and Cooling calls for the development of Intermediate Minimum Property Standards and Definitive Performance criteria.6/ As part of a program for the development of these standards and performance criteria, a State legislation survey of enacted State bills and subsequent State action was conducted to ensure that the results of State activities were incorporated in the Federal Standards development program.

1/ Section 103 Public Law 93-438, October 11, 1974.

2/ "Administrator" means the Administrator of the Energy Research and Development Administration (ERDA).

3/ "National Program for Solar Heating and Cooling (Residential and Commercial Applications)", ERDA-23A, Energy Research \& Development Administration, October 1975.

4/ The laws are:

-Solar Heating and Cooling Demonstration Act of 1974, P.L. 93-409

September 3, 1974 .

-Energy Reorganization Act of 1974, P.L. 93-438, October 11, 1974.

-Solar Energy Research, Development, and Demonstration Act of 1974 , P.L. 93-473, October 26, 1974.

-Federal Nonnuclear Energy Research and Development Act of 1974 , P.L. 93-577, December 31, 1974.

5/ For a summary of all building energy related bills considered in 1975, see Eisenhard, Robert. M., National Bureau of Standards, "Building Energy Authority and Regulations Survey: State Activity", NBSIR 76-986, March 1976.

6/ Tasks B.3 and B.4 of Residential and Commercial Demonstration Programs, ERDA-23A, October 1975. 


\section{Overview}

In 1975, over 120 State legislative proposals dealing with the application of solar energy to buildings were introduced in the United States. Approximately one sixth of these proposals were enacted. It is expected that some of these remaining will be reintroduced in 1976 and those on which no final action was taken will be considered further. This legislation dealt with diverse subjects, although most provided a monetary incentive for the conversion to or initial use of, solar energy devices or systems to provide building heating, cooling or hot water. This incentive was to be provided by a reduced property assessment, an income tax reduction, or in sales, use or corporate tax exemption. Other bills authorized building code provisions or standards, research and development, State building uses of solar energy, easements or zoning requirements, and State solar energy centers.

This report provides detailed information on 34 bills enacted by several States in 1974 and 1975. A number of Acts relating to solar energy were reported in publications which are listed in the bibliography on page 41 of this report. State reference services and various responsible State agencies were contacted by letter and telephone to gain additional information. Copies of forms, informational documentation and/or standards that would enable implementation of the State Acts were requested. No standards development was reported.

The report is arranged to provide specific information on each Act in the report, with supporting forms, instructions or other data in Appendix A and the complete legislation or pertinent pages of the legislation included in Appendix B. In each case, the material is presented in alphabetical order by State.

Figures 1, 2 and 3 provide an overview of State activity regarding solar energy. Ten States (Figure 1) have Acts to provide a property tax incentive for the installation and use of solar devices:

Arizona SB 1231
Colorado SB 75
Illinois HB 164
Indiana SB 223
Maryland HB 1604

Montana HB 663

New Hampshire HB 479

North Dakota SB 2439

Oregon HB 2202

South Dakota SB 283

The property tax incentive in four Acts provides that the assessment of property equipped with the solar system or device will not be increased, i.e., the solar equipment is exempt. Acts in this category are: Arizona SB 1231, Oregon HB 2202, Montana HB 663 and North Dakota SB 2439. Two State Acts provide that a reduction of assessment relating to the solar system may be made for up to $\$ 2,000$. These are Indiana SB 223 and South Dakota SB 283. Maryland HB 1604 and Illinois HB 164 allow for assessment of the solar system as if the cost of the system were the same as a conventional system. New Hampshire HB 479 allows towns and cities to exempt solar systems with the amount and manner of exemption to be determined by the town. Colorado SB 75 sets the assessed value of 
Hawaii

SB 1586. . . $\frac{\text { Page }}{18}$

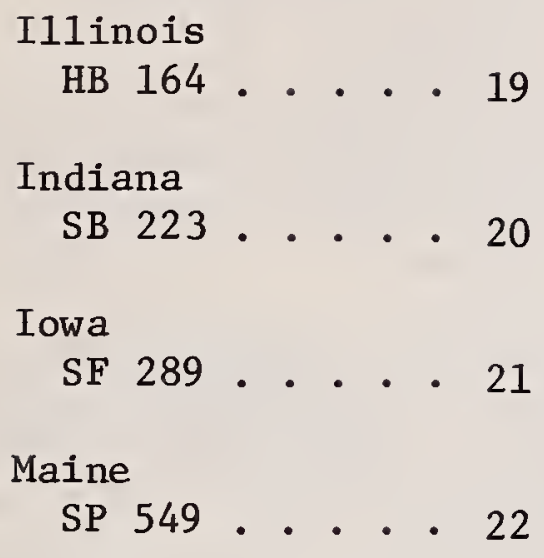

Maryland

HB 1604. . . 23

Michigan

HR 129 . . . 24

Montana

SB 86. . . . 25

HB 663 . . 26

Nevada

SB 552 . . 27

New Hampshire

HB 479 . . . 28

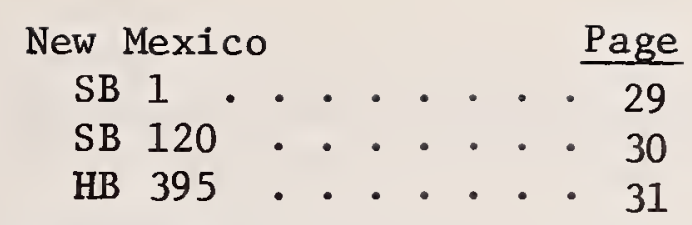

New York

$A B \quad 8620 \ldots 32$

North Carolina

SB 375 . . . 33

North Dakota

SB 2439 . . . 34

Ohio

Amended Substitute

HB 584 . . . . 35

Oregon

HB 2036 . . . • 36

HB 2202 . . . . 37

South Dakota

SB 283 • . . 38

Texas

HB 546 . . . . 39

Virginia

$\mathrm{HB} 1809$.... . 40

Key to Legislative Abbreviations

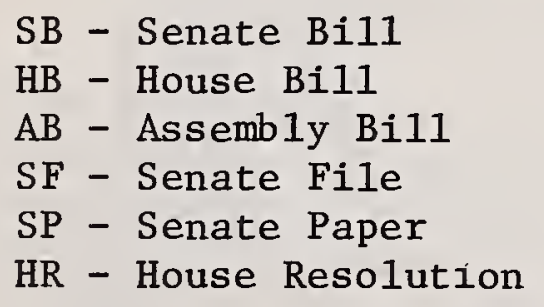

\section{Definitions:}

A bill is a form or draft of a proposed statute presented to a legislature. Bills may be proposed in any body of the legislature, such as the Senate, House or Assembly. A bill is termed a "House Bill" or "Senate Bill" depending on the legislative body which originally proposed the statute. The term, Assembly, is equivalent to the term, House. Some states use the terms, files and papers, which are equivalent to bills. A resolution effects the operation of the legislative body and if passed, does not become law, but is published in an appropriate document. 
the solar device at $5 \%$ of the actual value. The Arizona and Oregon bills provide the tax incentive for ten years while in South Dakota and North Dakota the time limit is five years.

Two States (Figure 2) provide income tax incentives for solar device use: Arizona SB 1231 and SB 1011; and New Mexico SB 1. A sales tax incentive is provided by Texas $\mathrm{HB}$ 546. Solar easements or zoning considerations are addressed in Colorado SB 95 and Oregon HB 2036.

New Mexico HB 395 requires the consideration of solar systems for new State building construction or major alterations of buildings that are State financed. Florida SB 158 requires that new single family residences provide plumbing system accessibility for future addition of solar water heating devices.

Sixteen Acts of 15 States (Figure 3) provide for State support for solar energy research and development and the promotion of solar energy activities or solar investigations. These States are:

Arizona SB 1018
California AB 1575
Colorado SB 50
Florida SB 721
Hawaii SB 1586
lowa SB 289
Maine SP 447
Michigan HR 129

Montana SB 86 Nevada SB 552

New Mexico SB 120 and SB 185 New York AB 8620 North Carolina HB 375 Ohio HB 584 Virginia HB 1809

In 1975, the solar energy activity and interest observed at the State level was equal to approximately one half of all the bills on building energy that were considered. It can be expected that 1976 will see continued concern for the encouragement of solar energy development as an alternative to fossil fuels.

\section{State Legislation Review}

Data for each Act includes approval and effective date, a brief abstract and the legal citation. To allow future access to detailed information on program development relating to these State acts, the State agency and name of the State official were determined and 1isted. Additional information pertaining to these Acts, the agency involved or related activities is also noted.
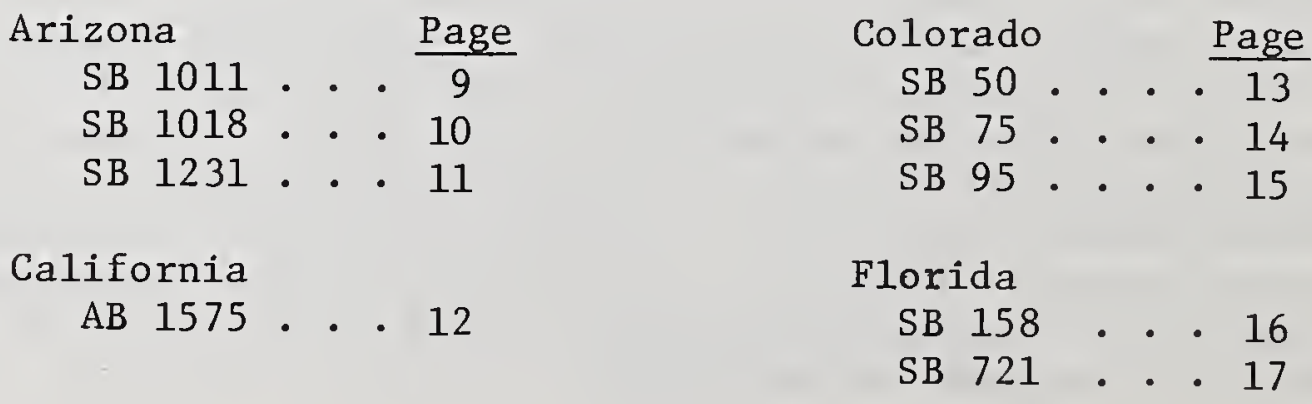


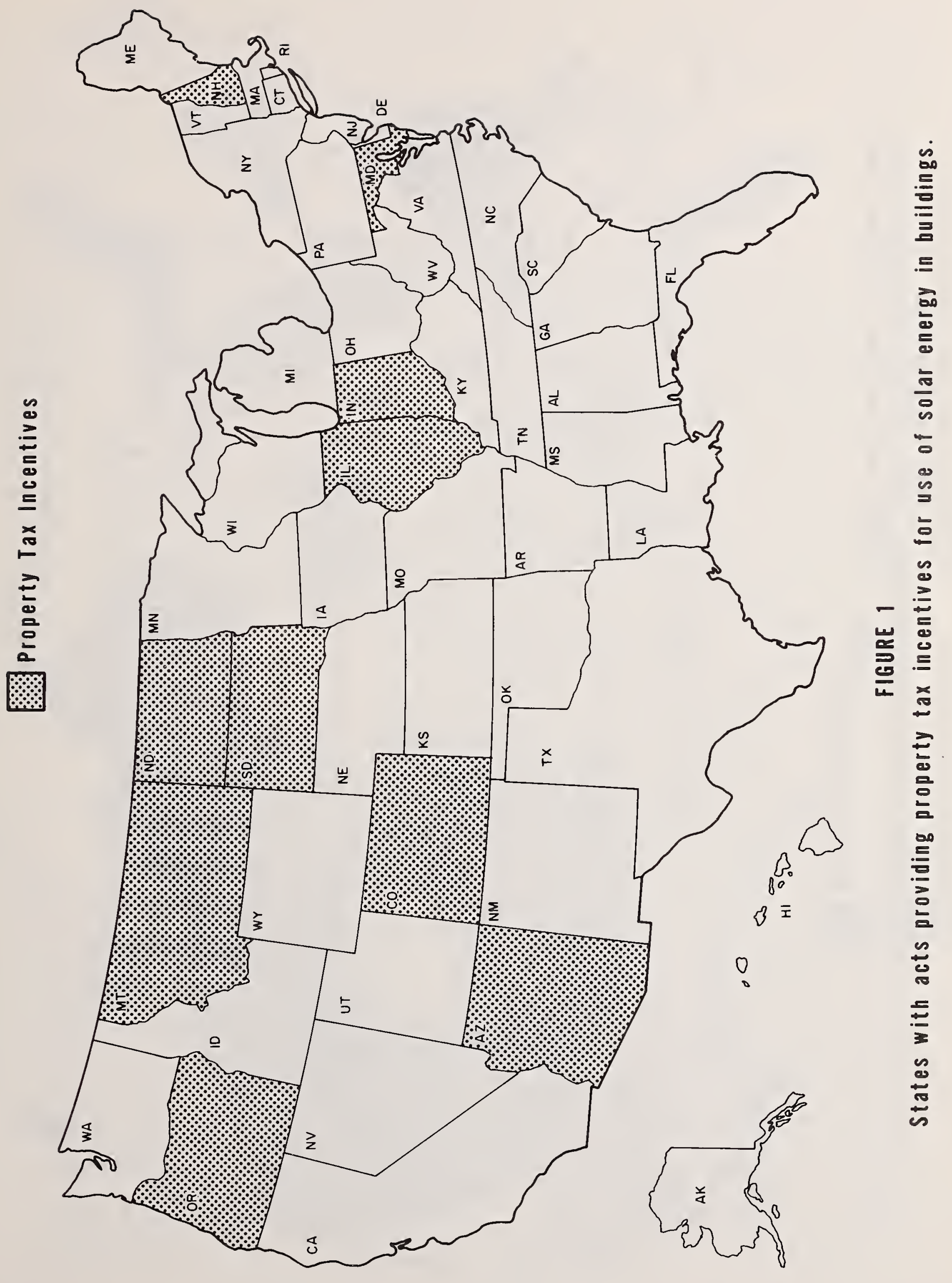




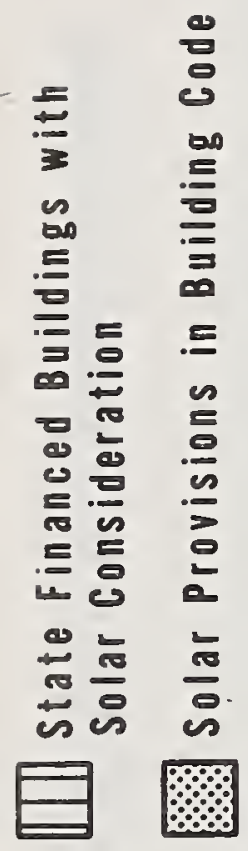
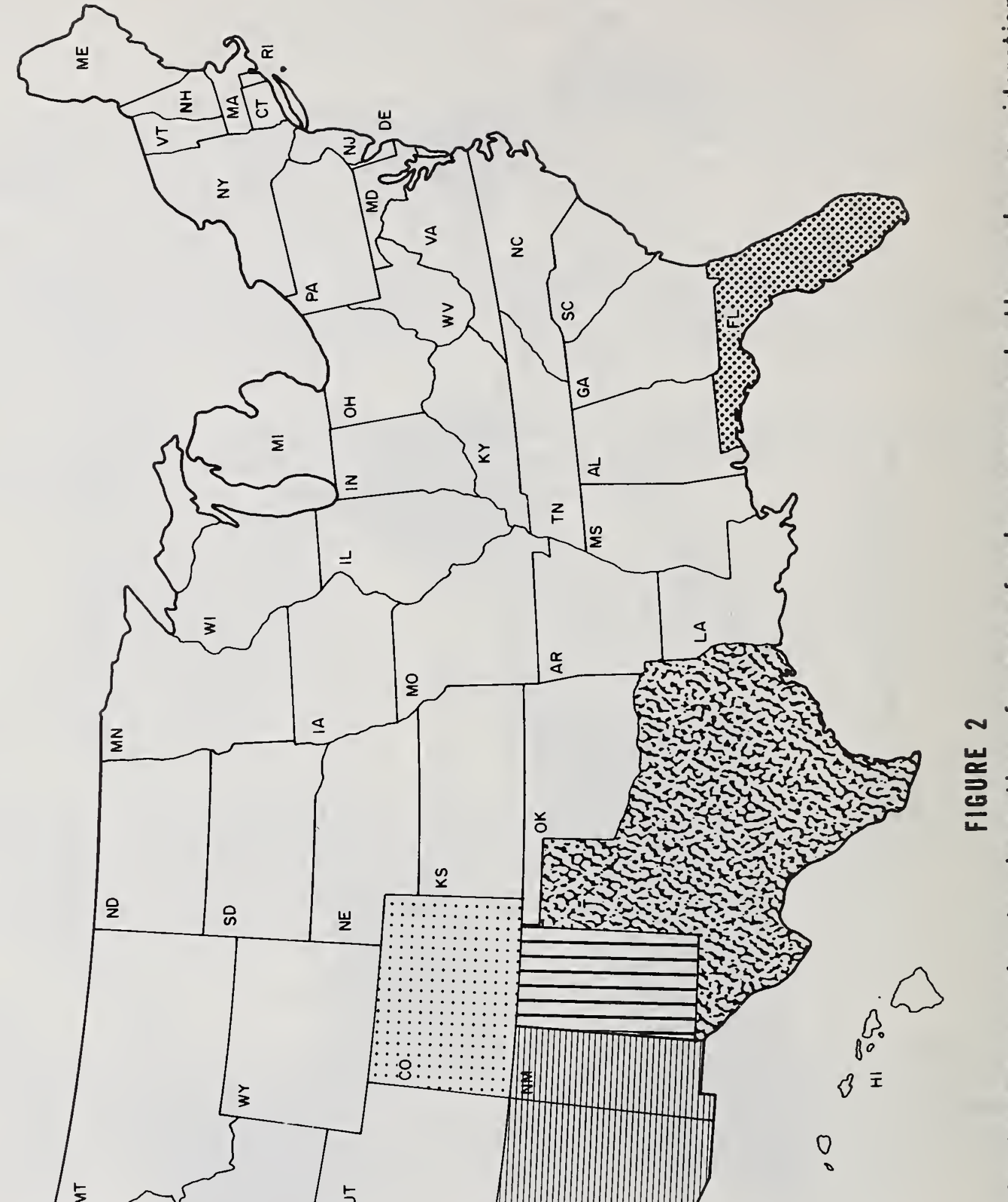

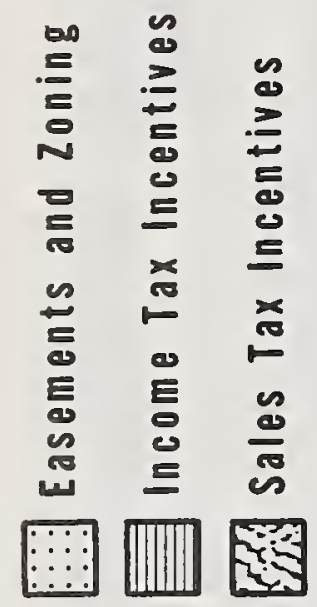

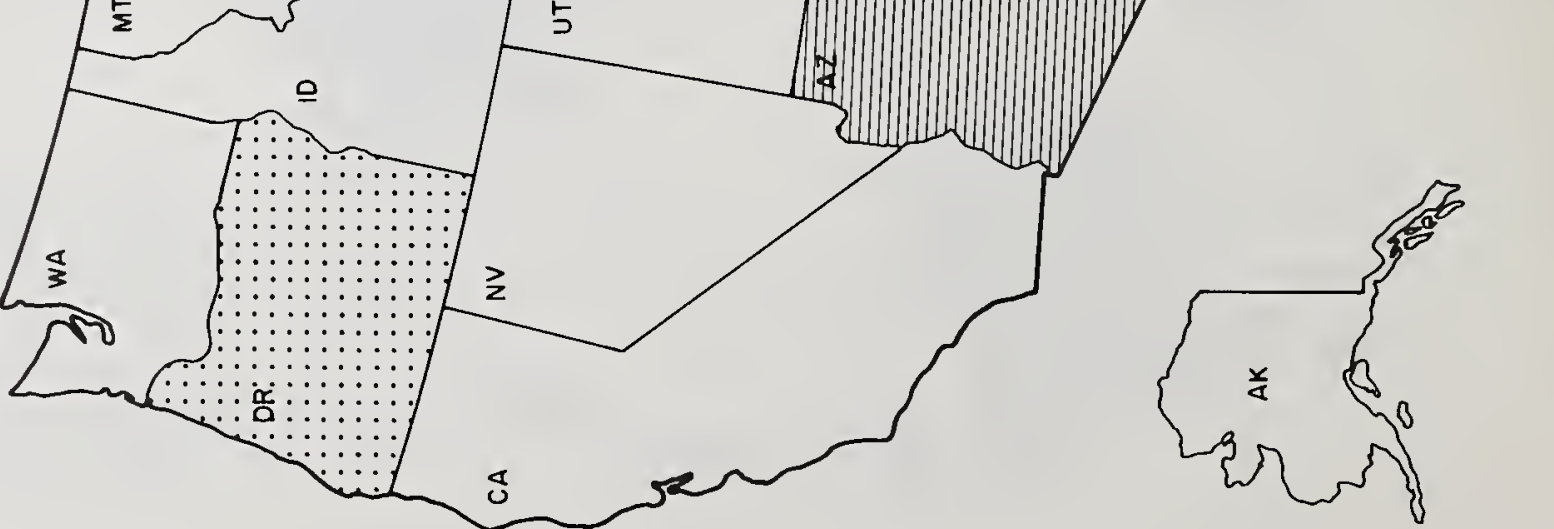




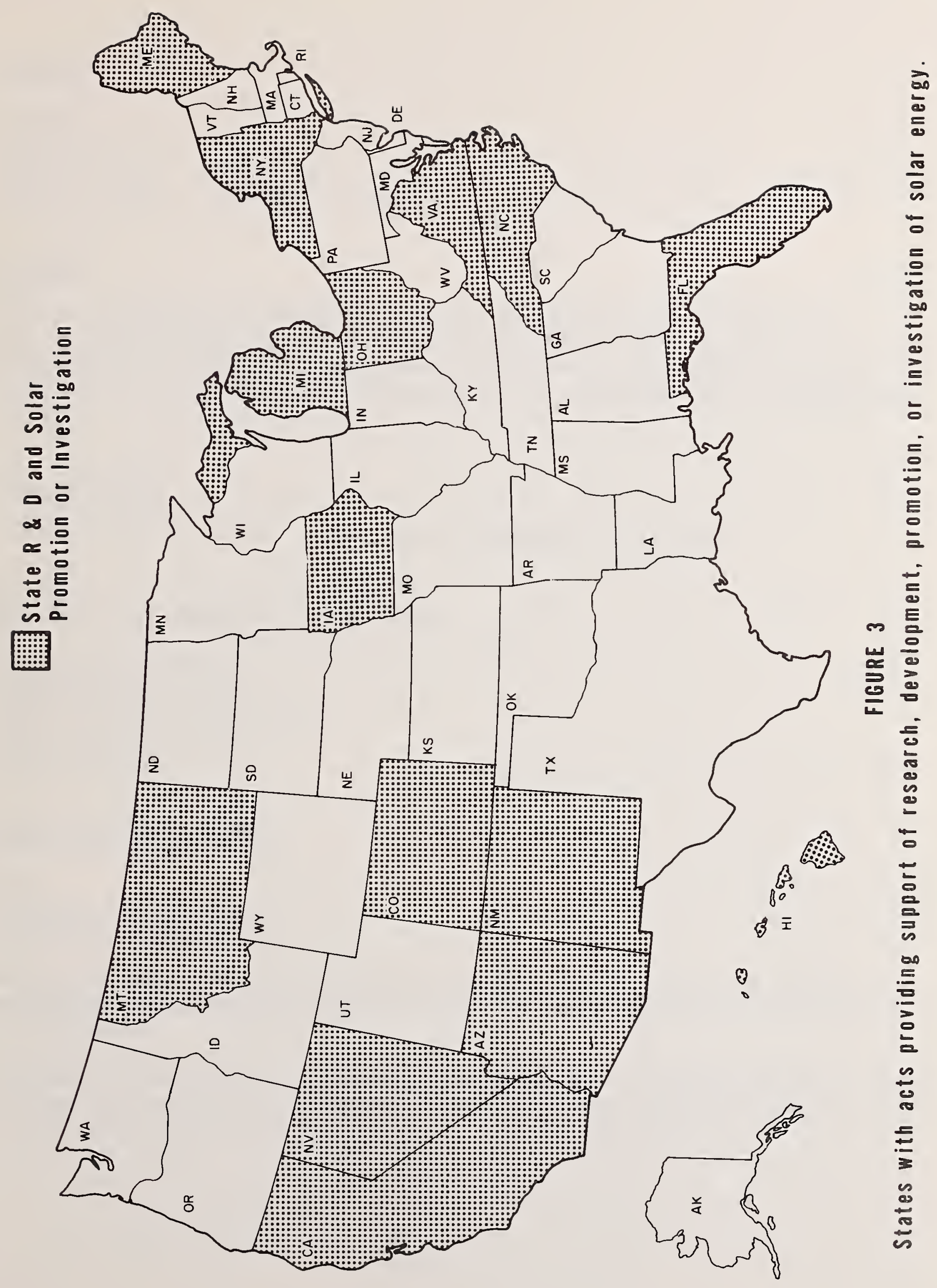



SB 1011

Chapter 93

Approval Date: May 22, 1975

Effective Date: September 12, 1975

\section{$\underline{\text { ABSTRACT }}$}

This Act provides for amortizing the cost of solar energy devices over sixty months as a deduction in computing net income. It applies to the installation and use of solar energy devices in residential, commercial, industrial or governmental installations, or in experimental or demonstration projects.

\section{LEGAL CITATION}

Section 43-123.37 of the Arizona Revised Statutes is amended.

RESPONSIBLE STATE AGENCY AND OFFICIAL

Neal Trasente, Director

Department of Revenue

Capitol Building - West Wing

Phoenix, Arizona 85007

(602) 271-3393

FORMS OR OTHER DOCUMENTS

None.

\section{ADDITIONAL INFORMATION}

This Act extends authority for a tax deduction to all types of buildings. Residential buildings were previously covered under SB 1231, Chapter 165 of the 1974 Laws.

Although no standards or technical requirements have been determined for solar hardware, Arizona does have license requirements for individuals installing the equipment through the State Registrar of Contractors. 
$\underline{\text { ARIZONA }}$

SB 1018

Chapter 20

Approval Date: May 8, 1975

Effective Date: May 8, 1975

\section{ABSTRACT}

This Act establishes a Solar Energy Research Commission and provides for the appointment of the Commission's Executive Director by the Governor. The Director is responsible for: (1) initiating and developing a systematic plan designed to meet all of the requirements of the National Solar Energy Research Institute: (2) cooperating with all Federal agenceies with respect to solar energy research; (3) collecting, assemblying and analyzing information and data relating to solar energy technology and legislation; and, (4) recommending an organizational structure for the Institute that will provide the functional properties necessary to execute the development of research requirements and programs.

\section{LEGAL CITATION}

Title 41, Chapter 3, Article 6, Arizona Revised Statutes is repealed. Title 41, Chapter 3, Arizona Revised Statutes, is amended by adding a new Article 6.

\section{RESPONSIBLE STATE AGENCY AND OFFICIAL}

Dr. Robert M. Handy

Executive Director

Solar Energy Research Commission

1645 West Jefferson Room 435

Phoenix, Arizona 85007

(602) 271-3682

FORMS OR OTHER DOCUMENTS

Copies of Memorandum submitted to the Governor are available.

\section{ADDITIONAL INFORMATION}

Commission projects include efforts to locate the National Solar Energy Research Institute in Arizona, initiating of a technical marketing activity for solar development and commercialization, developing a load management and solar integration study, establishing a feasibility study on solar heating and cooling of four State buildings, conducting a climatological survey, and providing for a solar irrigation pump contest.

The Commission consists of 15 appointed and two Ex Officio members. 


\section{ARIZONA}

SB 1231

Chapter 165 of 1974 Laws

Approval Date: May 15, 1974

Effective Date: January 1, 1974

\section{ABSTRACT}

This Act provides tax incentives for the installation of solar energy equipment in new and existing housing. Provides that residents who purchase solar energy equipment for their homes will not be assessed for the increased value of the dwelling as a result of that improvement and will be allowed to amortize the cost of the solar energy equipment over 60 months for purposes of reporting income for Arizona State taxes. The deduction is taken in lieu of depreciation.

\section{LEGAL CITATION}

Amending Title 42, Chapter 1, Article 2, Arizona Revised Statutes by adding Section 42-123.01, and amending Title 43, Chapter 1, Article, Arizona Revised Statutes by adding Section 43-123.37.

\section{RESPONSIBLE STATE AGENCY AND OFFICIAL}

Neal Trasente, Director

Department of Revenue

Capitol Building - West Wing

Phoenix, Arizona 85007

(602) 271-3393

FORMS OR OTHER DOCUMENTS

None.

\section{ADDITIONAL INFORMATION}

For additional information call:

Income and Withholding Taxes

(602) 271-4561 or Property and Special Taxes (602) 271-5238 


\section{CALIFORNIA}

$\mathrm{AB} 1575$

Chapter 276 Laws of 1974

Approval Date: May 21, 1974

Effective Date: January 7, 1975

\section{ABSTRACT}

This Act establishes the authority for a comprehensive energy program including research into and development of alternative sources of energy. Accelerated development of solar energy resources is specifically included (Chapter 7 25600 (c)).

\section{LEGAL CITATION}

This Act amends Section 21100 and adds Division 15 to the Public Resources Code and repeals Chapter 11 (commencing with Section 19870) of Part 3 of Division 13 of the Health and Safety Code.

\section{RESPONSIBLE STATE AGENCY AND OFFICIAL}

Richard L. Maullin, Chairman

Energy Resources Conservation and Development Commission

1111 Howe Avenue

Sacramento, California 95825

(916) $322-3690$

\section{FORMS OR OTHER DOCUMENTS}

(see below)

\section{ADDITIONAL INFORMATION}

Informational mailings on Commission activities may be obtained from Mary Ann Miller, Secretary of the Commission at the above address. Phone (916) 322-4527

Robert Foster is Chief, Conservation Division (916) 322-4520

Alec Jenkins, Acting Chief, Alternate Energy Resources and Technology Office (916) 322-6316 


\section{COLORADO}

\section{SB 50}

Chapter 95 Laws of 1974

Approval Date: May 8, 1974

Effective Date: May 8, 1974

\section{ABSTRACT}

This Act creates the Energy Research Institute at the Colorado School of Mines. The appropriation for $1974-1975$ was $\$ 910,000$. The Institute is intended to serve as a mechanism for the development and coordination of energy and energy-related minerals research programs. It is also intended to enhance the development of related educational programs in the State. An advisory council to establish guidelines and regularly evaluate the development of the Institute is established.

\section{LEGAL CITATION}

Article 9 of Chapter 124, Colorado Revised Statutes 1963, as amended, is amended by the addition of the following new sections: 124-9-19, 124-9-20.

\section{RESPONSIBLE STATE AGENCY AND OFFICIAL}

Thomas J. Vogenthaler, Director

Energy Research Institute

P. 0.366

Golden, Colorado 80401

(303) 279-2881

FORMS OR OTHER DOCUMENTS

None.

\section{ADDITIONAL INFORMATION}

The Energy Research Institute awarded $\$ 126,000$ to ten solar energy projects. The Institute also received $\$ 27,800$ from the Governor's Office to develop Colorado's proposal for location of the Federal Solar Energy Research Institute in Colorado. 


\section{COLORADO}

SB 75

Chapter 344 Laws of 1975

Approval Date: July 14, 1975

Effective Date: July 1, 1975

\section{ABSTRACT}

This Act provides that all solar heating, hot water and cooling devices attached to or part of any building improvement shall be assessed at five percent of the actual value, as determined by the assessor.

\section{LEGAL CITATION}

This Act adds a new Subsection (6) to 39-1-104; Colorado Revised Statutes 1973, and amends 39-5-105.

\section{RESPONSIBLE STATE AGENCY AND OFFICIAL}

Raymond E. Carper

Property Tax Administrator

Colorado Division of Property Taxation

614 Capitol Annex

Denver, Colorado 80203

(303) 892-2371

in cooperation with 63 Countw Assessors.

\section{FORMS OR OTHER DOCUMENTS}

Solar Heating or Cooling Devices, Form CST 510 11-75.

There is also an instruction sheet for completion of the form.

\section{ADDITIONAL INFORMATION}

SB 75 applies to tax years beginning January 1, 1976.

Correspondence with the Colorado Division of Housing indicates "that local building departments throughout the State are attempting to accommodate proposed solar systems and devices within the context of existing building codes." 


\section{SB 95}

Chapter 326 Laws of 1975

Approval Date: July 18, 1975

Effective Date: July 18, 1975

\section{ABSTRACT}

This Act provides for the creation, conveyance and recordation of solar easements. It describes such instrument to include, but not be limited to: (1) verticle and horizontal angles, expressed in degrees at which the solar easement extends over the real property; (2) terms or conditions under which the easement is granted or will be terminated; and, (3) provisions for compensation in event of interference with the easement or compensation for the easement.

\section{LEGAL CITATION}

Title 38, Colorado Revised Statutes 1973, as amended, is amended by the addition of Article 32.5, Solar Easements.

\section{RESPONSIBLE STATE AGENCY AND OFFICIAL}

The responsibility for this Act rests with the State's 63 county clerks and recorders.

FORMS OR OTHER DOCUMENTS

None. 
FLORIDA

SB 158

Chapter 74-361 Section 553.87 of the Florida Statutes

Approval Date: July 1, 1974

Effective Date: October 1, 1974

\section{ABSTRACT}

This Act provides that no single family residence shall be constructed in the State unless the plumbing is designed to facilitate the future installation of solar water heating equipment.

\section{LEGAL CITATION}

Section 553.70 - 553.87 of the Florida Statutes (cited as the "Florida Building Codes Act of 1974") includes the following as 553.87: "Single-family residences; solar water heating requirements. Notwithstanding the provisions of ss 553.12 and 553.13, no single-family residence shall be constructed within the State unless the plumbing therein is designed to facilitate the future installation of solar water-heating equipment. The words 'facilitate the future installation' as used in this section shall mean the provision of readily accessible piping to allow for pipe fittings that will allow easy future connection into the system of solar water-heating equipment. It is the intent of the legislature to minimize cost of rearranging plumbing should solar water heaters be added to buildings."

\section{RESPONSIBLE STATE AGENCY AND OFFTCIAL}

John H. Haslam, Chief

Bureau of Codes and Standards

Department of Community Affairs

2571 Executive Center Circle, East

Tallahassee, Florida 32301

(904) 488-3581

\section{FORMS OR OTHER DOCUMENTS}

None.

\section{ADDITIONAL INFORMATION}

The Chief of the Bureau of Codes and Standards states in a letter dated January 5, 1976," . . . we feel the following to be one method that satisfies the intent. Tee fittings can be installed in both the inlet and outlet piping of the hot water heater as close to the heater as practical. Then short nipples can be added to the branch of each of the tees and these nipples capped. The caps are easily removed when it is desired to connect solar water-heating equipment in the future." 
SB 721

Chapter 74-185

Approval Date: June 17, 1974

Effective Date: July 1, 1974

\section{ABSTRACT}

This Act requires the Board of Regents of the State University System to develop a plan for a Solar Energy Center. The purpose of the Center is to promote solar energy research and development, disseminate information and demonstrate solar systems' capabilities. The Center's program includes the development of test methods for testing solar equipment and the development of standards, as required.

\section{LEGAL CITATION}

None.

\section{RESPONSIBLE STATE AGENCY AND OFFICIAL}

Dr. Howard P. Harrenstein

Director

Florida Solar Energy Center

300 State Road 401

Cape Canaveral, Florida 32920

(305) 783-0300

FORMS OR OTHER DOCUMENTS

An organizational chart and a review of the Center's activities can be obtained from the Center.

\section{ADDITIONAL INFORMATION}

The Solar Energy Center plans were approved in 1975, and the Center became operative in June 1975. The legislature appropriated \$1 million for its operation. As of January 1, 1976, the Center's personnel numbered 28.

A test facility for flat plate solar energy collectors with supporting instrumentation and data processing is being constructed by the Center.

HB 776, prefiled for the 1976 session, directs the Florida Solar Energy Center to set standards for solar energy systems manufactured or sold in the State. 


\section{HAWAII}

\section{SB 1586}

Act $195-75$

Approval Date: June 2, 1975

Effective Date: July 1, 1975

\section{$\underline{\text { ABSTRACT }}$}

This Act provides $\$ 1,787,000$ over two fiscal years for the development and utilization of alternate energy sources.

\section{LEGAL CITATION}

Part V, Section 89, Economic Development, of the State Budget.

\section{RESPONSIBLE STATE AGENCY AND OFFICIAL}

Dr. Eugene M. Grabbe

Alternate Energy Director

Department of Planning and Economic Development

250 S. King Street

Honolulu, Hawaii 96813

(808) 548-6914

\section{FORMS OR OTHER DOCUMENTS}

"Alternate Energy Sources for Hawaii - 1975," and "Hawaii and Energy" (a brochure) are published by the Department of Planning and Economic Development.

\section{ADDITIONAL INFORMATION}

Funding will go to the Hawaii Natural Energy Institute, the Hawaii Natural Energy Laboratory, the University of Hawaii, and other State and private agencies. Solar water heating and air conditioning research funding is $\$ 200,000$ for the two fiscal years.

Approximately $50 \%$ of the total funding is from the State general funds and the remainder is from general obligation bond funds. 


\title{
ILLINOIS
}

HB 164

Public Act 79-943

Approval Date: September 11, 1975

Effective Date: October 1, 1975

\section{ABSTRACT}

This Act provides that when a solar energy heating or cooling system has been installed in an improvement on any real property, the owner of the property may claim an alternate valuation of that improvement. The alternate valuation is to be the lesser of the value of the improvement with a conventional heating or cooling system and the value of the improvement with the solar energy system.

\section{LEGAL CITATION}

This Act adds sections $20 d-1,20 d-2$, and $20 d-3$ to the "Revenue Act of 1939 " filed May 17, 1939 as amended.

\section{RESPONSIBLE STATE AGENCY AND OFFICIAL}

\author{
Frank A. Kirk, Director \\ Department of Local Government Affairs \\ 303 East Monroe Street \\ Springfield, Illinois 62706 \\ (217) 782-6436
}

\section{FORMS OR OTHER DOCUMENTS}

Application for Valuation Under Section 20d-3 of the Revenue Act of 1939 Relative to Solar Energy Heating or Cooling Systems.

\section{ADDITIONAL INFORMATION}

Standards, as required by the Act, have not been finalized but probably will be general such as "capable of heating or cooling when solar energy is available." No technical detail will be included.

For additional information contact: William Townsley, Chief Office of Financial Affairs

Department of Local Government Affairs 303 East Monroe Street Springfield, Illinois 62701

(217) 782-6956 


\section{INDIANA}

\section{SB 223}

Public Law 15, 1974

Approval Date: February 18, 1974

Effective Date: June 11, 1974

\section{ABSTRACT}

This Act allows the owner of real property with a solar energy heating or cooling system an annual deduction from the assessed value of the property equal to the lesser of: (1) the assessed value of the property with the solar system minus the assessed value without the system; or (2) two thousand dollars.

\section{LEGAL CITATION}

Indiana Code $1971,6-1$ is amended by adding a new chapter 9.5.

\section{RESPONSIBLE STATE AGENCY AND OFFICIAL}

This Act is administered by the County Auditor with verification by the Township Assessor. Any interpretation or clarification will be provided by the State Board of Tax Commissioners.

Gordon E. McIntyre, Secretary

State Board of Tax Commissioners

Room 201 State Office Building

Indianapolis, Indiana 46204

(317) 633-5659

or

Wayne Pruett, Director

Division of Property Valuation

State Board of Tax Commissioners

Room 201 State Office Building

Indianapolis, Indiana 46204

(317) 633-4675

FORMS OR OTHER DOCUMENTS

SES-1 Statement for Deduction of Assessed Valuation Attributed to Solar Energy System. 
IOWA

SF 289

Chapter 56 Laws of 1975

Approval Date: July 15, 1975

Effective Date: July 1, 1975

\section{ABSTRACT}

This Act establishes an energy research and development fund within the Energy Policy Council. The fund is to be used for research and development of projects designated to improve Iowa's energy situation. Private, State and Federal funds may be added to a State fiscal year appropriation of $\$ 250,000$.

\section{LEGAL CITATION}

This Act amends Chapter 93, Code 1975, by adding two new sections and provides an appropriation.

\section{RESPONSIBLE STATE AGENCY AND OFFICIAL}

Maurice Van Nostrand, Chairman

Energy Policy Council

Valley Bank Building

300 Fourth Street

Des Moines, Iowa 50319

(515) 281-3428

\section{FORMS OR OTHER DOCUMENTS}

"Guidelines for Preparation of Proposals to the Iowa Policy Council". The Council also publishes a "Quarterly Energy Report" and an annual report titled "Energy: 1976".

\section{ADDITIONAL INFORMATION}

Dr. Laurent Hodges, Research Director, is responsible for the energy research and development fund administration. (address and phone same as above). 
$\underline{\text { MAINE }}$

SP 549 (Legislative Document 1913)

(Introduced as SP 447, LD 1558)

Chapter 587

Approval Date: June 26, 1975

Effective Date: June 26, 1975

\section{ABSTRACT}

This Act mandates the appointment of a full time Director for the Office of Energy Resources and defines the powers and duties of the Director and the Office. The Act also establishes a State Energy Resources Advisory Board and the Maine Energy Development Fund. The Fund is to be used to encourage and promote practical development of alternate sources of energy. The Fund is to be administered by a three director board and 2 staff members. Funding for two fiscal years is $\$ 2,050,000$.

\section{LEGAL CITATION}

This Act relates to Title 5 of the Maine Revised Statutes Annotated and repeals and replaces Sections 5004 through 5007, and adds new Sections 5008 and 5009 .

\section{RESPONSIBLE STATE AGENCY AND OFFICIAL}

Abbie C. Page, Director Maine Office of Energy Resources

55 Capitol Street

Augusta, Maine 04330

(207) 289-2196

FORMS AND DOCUMENTS

None.

\section{ADDITIONAL INFORMATION}

Solar energy is not specifically mentioned in this act, but could be included within the general language. 
HB 1604

Chapter 509 of the Session Laws of 1975

Approval Date: April 22, 1975

Effective Date: July 1, 1975

\section{ABSTRACT}

This Act provides that solar energy heating and cooling units installed in existing or newly constructed residential or non-residential buildings, shall not cause the assessment of the building to be greater than with a conventional heating or cooling unit.

\section{LEGAL CITATION}

This Act adds a new subsection (b) (4) to Article 81, Section 14 of the Annotated Code of Maryland (1969 Replacement Volume and 1974 Supplement).

RESPONSIBLE STATE AGENCY AND OFFICIAL

Albert W. Ward, Administrator

Department of Assessment and Taxation

301 West Preston Street

Baltimore, Maryland 21201

(301) 383-2526

FORMS OR OTHER DOCUMENTS

None.

ADDITIONAL INFORMATION

Administrators do not expect early solar installations to increase values of real property. 


\section{MICHIGAN}

HR 129

Approval Date: July 2, 1975

Effective Date: July 2, 1975

\section{$\underline{\text { ABSTRACT }}$}

This resolution creates a special House committee to study the feasibility of statewide use of solar heating and cooling systems. This five member committee is to report its findings and recommendations to the Legislature not later than January 1977.

\section{LEGAL CITATION}

None.

RESPONSIBLE STATE AGENCY AND OFFICIAL

Rep. Lucille H. McCollough

Chairperson

Committee to Study the Feasibility of Statewide Use of Solar Heating and Cooling Systems

Room 0 3rd Floor

State Capitol

Lansing, Michigan 48901

(517) 373-0847

FORMS OR OTHER DOCUMENTS

None.

ADDITIONAL INFORMATION

Michigan has a Research Association known as:

Michigan Energy \& Resource Research Association (MERRA) 728 Executive Plaza Detroit, Michigan 48226

(313) $964-5030$

Mr. John Mogk, President

Mr. Dick Popeck, Energy Conservation

Mr. Dwight Bornemeier, Solar Energy 
MONTANA

SB 86

Chapter 501 Laws of 1975

Approval Date: April 29, 1975

Effective Date: July 1, 1975

\section{$\underline{\text { ABSTRACT }}$}

This Act creates a fund for research, development and demonstration of alternate renewable energy sources. The funds are to be derived from a $2-1 / 2 \%$ of all 1icense taxes or from a severance tax on coal until December 31,1979 when the percentage will increase to $4 \%$. The funds will be used for grants to any individual, business entity, educational or scientific institution or governmental unit. The program is under the Department of Natural Resources and Conservation.

\section{LEGAL CITATION}

This Act amends Section 84-1309.1 of the Revised Codes of Montana and adds seven new sections.

\section{RESPONSIBLE STATE AGENCY AND OFFICIAL}

Charles W. Greene, Program Manager

Department of Natural Resources and Conservation

30 South Ewing

Helena, Montana 59601

(406) 449-3780

FORMS OR OTHER DOCUMENTS

Sub-Chapter 18, "Alternative Renewable Energy Source Grants", Montana Administrative Code. 
MONTANA

HB 663

Chapter 548

Approval Date: May 13, 1975

Effective Date: July 1, 1975

\section{$\underline{\text { ABSTRACT }}$}

This Act encourages investment in nonfossil forms of energy generation and in energy conservation in buildings through tax incentives and capital availability.

\section{LEGAL CITATION}

This Act amends Sections 84-202 and 84-301 of the Revised Codes of Montana, 1947 and adds new Sections 84-7401 through 84-7406.

\section{RESPONSIBLE STATE AGENCY AND OFFICIAL}

William Groff, Director

Department of Revenue

Michell Building

Helena, Montana 59601

(406) $449-2460$

FORMS OR OTHER DOCUMENTS

$A B-12$, Application for Class 8 Assessment

AB-14, Application for Tax Incentive Assessment of Energy Generating Property

\section{ADDITIONAL INFORMATION}

A newspaper announcement relating to this Act is included with the forms. 
$\underline{\text { NEVADA }}$

SB 552

Chapter 636

Approval Date: May 20, 1975

Effective Date: May 20, 1975

\section{ABSTRACT}

This Act provides $\$ 370,000$ for designing, constructing, equipping and furnishing a solar energy laboratory in Clark County, Nevada, as an additional facility of the Desert Research Institute of the University of Nevada. Responsibility for this activity rests with the State Public Works Board and the Board of Regents of the University of Nevada.

\section{LEGAL CITATION}

None.

\section{RESPONSIBLE STATE AGENCY AND OFFICIAL}

William E. Hancock, AIA Chairman James L. Buchanan II Dr. Lloyd P. Smith Secretary and Manager State Public Works Board Nye Building, Room 225 Board of Regents Desert Research Inst. University of Nevada 405 Marsh Avenue

Carson City, Nevada 89701 Reno, Nevada 89509 University of Nevada (702) $885-4870$ (702) 784-4901 Reno, Nevada 89507 (702) 784-6131

FORMS OR OTHER DOCUMENTS

None.

\section{ADDITIONAL INFORMATION}

Bids on the Solar Energy Laboratory are expected to be elicited in the Spring of 1976. Construction is to follow in the summer.

The architect for this project is Harry Wood of the University of Nevada. 


\section{NEW HAMPSHIRE}

HB 479

Chapter 391 Laws of 1975

Approval Date: June 16, 1975

Effective Date: August 15, 1975

\section{ABSTRACT}

This Act allows each city and town to adopt, by local referendum, property tax exemptions for persons owning real property which is equipped with a solar energy heating or cooling system.

\section{LEGAL CITATION}

Amends Revised Statutes Annotated 72 by inserting after section 60 a new subdivision including sections 61-64.

\section{RESPONSIBLE STATE AGENCY AND OFFICIAL}

City or town assessors and selectmen

under general supervision of:

Lloyd M. Price, Commissioner

Department of Revenue Administration

19 Pillsbury Street

Concord, New Hampshire 03301

(603) 271-2191

\section{FORMS OR OTHER DOCUMENTS}

Solar Energy Systems Exemption Claim (implements the referendum action taken by Concord under this Act).

\section{ADDITIONAL INFORMATION}

Concord, New Hampshire took action under this Act by referendum on November 4, 1975. By mid-January 1976, one homeowner had applied for the solar exemption. Complete procedures have not been developed but they are planning to assess the property as if conventional heating systems were used. 
SB 1 (Special Session, 1975)

Chapter 12, Laws of 1975

Approval Date: Apri1 10, 1975

Effective Date: Apri1 10, 1975

\section{ABSTRACT}

This Act provides for a credit against personal income tax due, for conversion to or construction of a solar energy system, used in the taxpayer's principal residence. The credit is allowable equal to $25 \%$ of the cost of the equipment not to exceed $\$ 1,000$. It further provides for a refund to taxpayers if the credit allowed exceeds tax liability.

\section{LEGAL CITATION}

The Act is a new Section 72-15A-11.2 to the New Mexico Statutes Annotated 1953.

\section{RESPONSIBLE STATE AGENCY AND OFFICIAL}

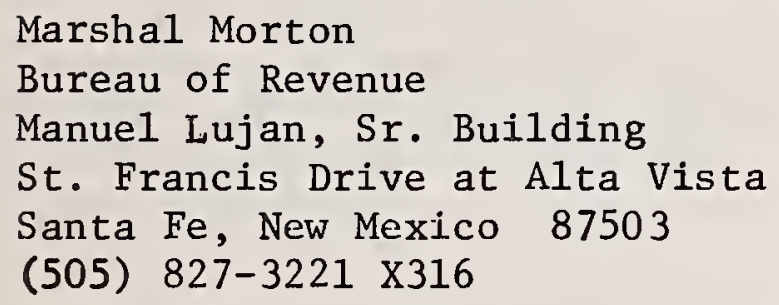

\section{FORMS OR OTHER DOCUMENTS}

None.

\section{ADDITIONAL INFORMATION}

A solar home is under construction in Las Cruces. For information contact Roy Moore, 206 E. Fleming Avenue, Las Cruces, New Mexico, 88001. Other solar construction and activities are described in "Solar Flair" (see SB 120). 


\section{NEW MEXICO}

SB 120

Chapter 83, Laws of 1975

Approval Date: April 2, 1975

Effective Date: April 2, 1975

\section{ABSTRACT}

This Act appropriates $\$ 30,000$ to the Department of Development to promote research, development and use of solar energy in New Mexico and to encourage the location of the proposed National Solar Institute in the State.

\section{LEGAL CITATION}

This Act may be cited as the "Solar Energy Development Act".

\section{RESPONSIBLE STATE AGENCY AND OFFICIAL}

Fabian Chavez, Jr., Director

Department of Development

113 Washington Avenue

State Security Building 2nd Floor

Santa Fe, New Mexico 87503

(505) 827-3101

FORMS OR OTHER DOCUMENTS

Solar Activity of Department of Development information sheet.

\section{ADDITIONAL INFORMATION}

A three man Task Force has been appointed by the Governor: Director Fabian Chavez, Jr., Dean Willian Gross, Dean John Hernandez. For additional information contact Al Dietz, Deputy Director, Department of Development at the address above.

"Solar Flair", a booklet published by the Department of Development, details New Mexico's private, university and public involve in solar energy. 


\section{NEW MEXICO}

HB 395

Chapter 200, Laws of 1975

Approval Date: April 7, 1975

Effective Date: April 7, 1975

\section{ABSTRACT}

This Act provides that a feasibility study on the use of energy sources other than fossil fuels for heating and cooling must be made prior to execution of a contract for construction or major alteration of any State owned building.

\section{LEGAL CITATION}

None.

RESPONSIBLE STATE AGENCY AND OFFICIAL

Tony R. Elias

Chief

Property Control Division

Department of Finance and Administration

Bataan Memorial Building Room 310

Santa Fe, New Mexico 87503

(505) 827-2404

FORMS OR OTHER DOCUMENTS

None. 
NEW YORK

$A B 8620$

Chapter 864 Laws of 1975

Approval Date: August 9, 1975

Effective Date: September 8, 1975

\section{ABSTRACT}

This Act redesignates the New York State Atomic and Space Development Authority as the New York State Energy Research and Development Authority (ERDA). The ERDA responsibilities include development and implementation of new energy sources, including solar. Included is authority to conduct, sponsor or assist research, development and demonstration programs in new energy technologies, to disseminate information, and to advise the legislature.

\section{LEGAL CITATION}

This Act is in Sections 1850-1872 of Title 9, Article 8 of the New York Pub1ic Authorities Law.

\section{RESPONSIBLE STATE AGENCY AND OFFICIAL}

Charles Baxter

Research Program Manager

New York State Energy Research and Development Authority

230 Park Avenue

Room 1235

New York, New York 10017

(212) 689-5070

\section{FORMS OR OTHER DOCUMENTS}

Recommended Budget for 1976-77. (Fiscal Year begins April 1, 1976)

\section{ADDITIONAL INFORMATION}

An annual report is available for the year April 1, 1974 - March 31, 1975, the last full year that the Authority operated under its previous legislative mandate.

Al Messina is Research Project Director for solar energy. 
HB 375

Chapter 911

Approval Date: June 26, 1975

Effective Date: July 1, 1975

\section{ABSTRACT}

This Act provides an appropriation of $\$ 30,000$ to North Carolina State University for research on and development of a working solar heating and cooling system for both residential and commerical buildings. Appropriations are divided into $\$ 20,000$ for fiscal $75-76$ and $\$ 10,000$ for fiscal ' $76-77$.

\section{LEGAL CITATION}

None.

\section{RESPONSIBLE STATE AGENCY AND OFFICIAL}

Dr. Frederick 0. Smetana

Department of Mechanical and Aerospace Engineering North Carolina State University

Raleigh, North Carolina 27607

(919) 737-2374

\section{FORMS OR OTHER DOCUMENTS}

None. 


\section{NORTH DAKOTA}

SB 2439

Chapter 508

Approval Date: April 8, 1975

Effective Date: July 1, 1975

\section{ABSTRACT}

This Act provides that systems utilizing solar energy for heating or cooling of new or existing builings will be exempt from property tax for five years following installation. If a building has a conventional heating or cooling system which is supplemented by a solar energy system, only the solar energy portion of the system shall be exempt.

\section{LEGAL CITATION}

This Act forms a new subdivision 27, to section 57-02-08 of the North Dakota Century Code.

RESPONSIBLE STATE AGENCY AND OFFICIAL

John Hulteen, Supervisor of Assessments

State Tax Department

State Capitol

Bismarck, North Dakota 58505

(701) 224-3461

\section{FORMS OR OTHER DOCUMENTS}

None. 
$\underline{\mathrm{OHIO}}$

Amended Substitute HB 584

File No. 116

Approval Date: August 26, 1975

Effective Date: August 26, 1975

\section{$\underline{\text { ABSTRACT }}$}

This Act establishes the Ohio Energy and Resource Development Agency (ERDA) replacing the Ohio Energy Commission and the Ohio Development Center. The Agency is to sponsor research and award grants and contracts for experimental demonstration facilities and projects which provide new or alternate energy sources. The legislation includes solar heating and cooling demonstrations.

\section{LEGAL CITATION}

This Act amends Section $122.09,122.63$ to 122.73 and 123.01 , and adds new Sections $122.671,122.74$ to 122.87 and 5709.30 to 5709.37 and repeals Section 122.08 of the Ohio Revised Code.

\section{RESPONSIBLE STATE AGENCY AND OFFICIAL}

Robert S. Ryan, Director

Ohio Energy and Resource Development Agency

30 E. Broad Street

25th Floor

Columbus, Ohio 43215

(614) 466-3465

FORMS OR OTHER DOCUMENTS

None.

\section{ADDITIONAL INFORMATION}

The Legislature appropriated $\$ 5$ million for 1975-76 and 1976-77. Each year the division of funds is to be $\$ 500,000$ for operating expenses and $\$ 2$ million for program development.

HB 1309 , clarifying the authority of OERDA, has been introduced in the Ohio Legislature. 
OREGON

HB 2036

Chapter 153 Laws of 1975

Approval Date: May 19, 1975

Effective Date: September 13, 1975

\section{ABSTRACT}

This Act adds solar energy considerations to comprehensive planning and allows county planning commissions to recommend ordinances governing height and set back of buildings and assuring access to incident solar energy. It allows city planning commissions to recommend zoning ordinances limiting the use, height, area and bulk of buildings and structures, and recommends appropriate public incentives for overall energy conservation.

\section{LEGAL CITATION}

This Act amends ORS 215.055, 215.110, 227.090 and 227.230.

RESPONSIBLE STATE AGENCY AND OFFICIAL

Lon Topaz, Director

Department of Energy

528 Cottage Street, N. E.

Salem, Oregon 97310

(503) $378-4128$

FORMS OR OTHER DOCUMENTS

None. 
HB 2202

Chapter 460 Laws of 1975

Approval Date: June 30, 1975

Effective Date: September 13, 1975

\section{ABSTRACT}

This Act provides an exemption from ad valorem taxation for any increased value of property resulting from installation and use of a solar energy heating or cooling system. Applies to assessment years beginning on and after January 1, 1976, but not on or after January 1, 1986.

\section{LEGAL CITATION}

None.

RESPONSIBLE STATE AGENCY AND OFFICIAL

Donald M. Fisher, Administrator Assessment and Appraisal Division 506 State Office Building Salem, Oregon 97310

(503) 378-3378

FORMS OR OTHER DOCUMENTS

None. 
SB 283

Chapter 111

Approval Date: March 25, 1975

Effective Date: July 1, 1975

\section{ABSTRACT}

This Act allows the owner of residential real property an annual deduction from its assessed valuation for the installation of a solar heating, solar hot water or solar cooling device. The deduction from the assessed valuation may be equal to the lesser of: (1) the remainder of the assessed valuation of the real property with the solar heating or cooling system included, minus the valuation of the real property without the system; or (2) two thousand dollars. The Act expires July 1, 1980.

\section{LEGAL CITATION}

South Dakota Compiled Law 10-6-35.5, 10-6-35.6, 10-6-35.7

RESPONSIBLE STATE AGENCY AND OFFICIAL

County Auditors/Assessors and

Lyle Wende11, Secretary

Department. of Revenue

State Capitol

Pierre, South Dakota 57501

FORMS OR OTHER DOCUMENTS

SD Rev PT8 9-75, "Claim for Solar Heating and Cooling. Allowance".

\section{ADDITIONAL INFORMATION}

1. The owner of real property who desires to claim a deduction must file a statement with the county auditor in his county. The owner is required to file a claim on forms prescribed by the Department of Revenue. The county assessor is responsible for verifying such declared deductions.

2. The Administrative Rules of South Dakota 64:02:01:27 provide the following definition: "Solar heating and cooling - Defined - Exclusions. A solar heating or cooling system is one which has as its direct source of energy, the sun, transmitted by sun collectors or converters through the absorption of rays. To qualify as a solar heating or cooling system the conversions system must be so designed to focus the suns rays onto a collector; to convert those rays into a usable form of energy; storing such energy until needed, and able to deliver the energy to its intended use. No device which does not make use of the rays of the sun in the process of heating or cooling shall qualify. This is intended to exclude devices for heat transference from elements or materials which are incidentially warmed such as the air or ground water unless directly connected with a sun collector". 
HB 546

Filed without signature: June 21, 1975

Effective Date: September 1, 1975

\section{$\underline{\text { ABSTRACT }}$}

The solar energy portion of this Act provides that corporations which exclusively manufacture, sell and install solar energy devices are excluded from the franchise tax. It also provides exemption from taxes of receipts from the sale, lease or rental of solar energy devices. A corporation may deduct from its taxable capital the amortized cost of a solar energy device for production of energy or heating and cooling. The cost may be amortized for any period not less than 60 months.

\section{LEGAL CITATION}

This Act, as it relates to solar energy devices, amends the General Revised Civil Statutes of Texas, 1925 as amended; by amending Article 12.03;

Title 122A, Taxation. It also amends by adding Section (CC) to Article 20.04, and Section (6) to Article 12.01 of the same Title and Statutes.

\section{RESPONSIBLE STATE AGENCY AND OFFICIAL}

Bob Bullock, Comptroller

Comptroller of Public Accounts

Lyndon Baines Johnson Building

17 th and Congress

Austin, Texas 78711

FORMS OR OTHER DOCUMENTS

None.

\section{ADDITIONAL INFORMATION}

The Act defines a solar energy device as "a system or series of mechanisms designed primarily to provide heating or cooling or to produce electrical or mechanical power or both by means of collecting and transferring solargenerated energy and includes mechanical or chemical devices having the capacity for storing solar-generated energy for use in heating or cooling or in the production of power". 


\section{VIRGINIA}

HB 1809

Chapter 331 Laws of 1975

Approval Date: March 18, 1975

Effective Date: June 1, 1975

\section{ABSTRACT}

This Act creates a Virginia Solar Energy Center within the Science Museum of Virginia. The Center's responsibilities include promoting solar utilization, coordinating State and Federal solar programs, serving as a technical information clearinghouse, and providing educational and policy development.

\section{LEGAL CITATION}

This Act adds section 9-65.2:1 to the Code of Virginia.

\section{RESPONSIBLE STATE AGENCY AND OFFICIAL}

Wynn Solomon, Director

Virginia Solar Energy Center

Virginia Science Museum

217 Governor Street

Richmond, Virginia 23219

(804) 786-4133

\section{FORMS OR OTHER DOCUMENTS}

None. 
1. Principal Legislative Staff Offices, The Council of State Governments, Iron Works Pike, Lexington, Kentucky 40511, September 1975.

2. "Energy Legislation Update", the Council of State Governments, Energy Project, Iron Works Pike, Lexington, Kentucky 40511, Bi-weekly publication.

3. "Turning Toward the Sun", Vol. One. Abstracts of State Legislative Enactments of 1974 and 1975 Regarding Solar Energy, National Conference of State Legislatures.

4. Ecp Report, Newsletter of the Energy Conservation Project, Environmental Law Institute, October 1975, January 1976.

5. "Recent Accomplishments in Tasks related to Solar Water Heating Application", Florida Solar Energy Center, Cape Canaveral, Florida 32920, September 26, 1975.

6. Cohen, Jeffrey C., White, Ronald H., "Energy Conservation in Buildings: The New York Metropolitan Region", Environmental Law Institute, Washington, D. C., July 1975 .

7. Eisenhard, Robert M., "Building Energy Authority and Regulations Survey: State Activity", National Bureau of Standards (U.S.), NBSIR 76-986, 48 pages, March 1976.

8. Ruegg, Rosalie T., "Assessing the Impact of Incentives on the Cost of Owning a Solar Energy System", National Bureau of Standards Report, (In Press). 

APPENDIX

A STATE FORMS, INSTRUCTIONS, DATA

B STATE LEGISLATION 

COLORADO SB 75

"Solar Heating or Cooling Devices," Form CST $51011-75$. . . . . . $\frac{\text { Page }}{\mathrm{A}-1}$

Instruction Sheet for CST $51011-75$. . . . . . . . . . . . A-2

ILLINOIS HB 164

"Application for Valuation Under Section 20d-3 of the Revenue Act

of 1939 Relative to Solar Energy Heating or Cooling Systems" . . . . . . A-3

INDIANA SB 223

SES-1 "Statement for Deduction of Assessed Valuation Attributed to Solar Energy System" . . . . . . . . . . . . . . . A-4

IOWA SF 289

"Guidelines for Preparation of Proposals to the Iowa Policy Council" . A-5

MONTANA SB 86

Sub-Chapter 18, "Alternative Renewable Energy Source Grants,"

Montana Administrative Code . . . . . . . . . . . . . . . A-6

MONTANA SB 663

$A B$ 12, "Application for Class 8 Assessment" . . . . . . . . . . . . . A-15

$A B$ 14, "Application for Tax Incen'tive Assessment of Energy

Generating Property" . . . . . . . . . . . . . . . . A-16

Great Falls, Montana, Tribune article, March 8, 1976 . . . . . . . A-17

NEW HAMPSHIRE HB 479

"Solar Energy Systems Exemption Claim" (Concord, New Hampshire) . . . . A-18

NEW MEXICO SB 120

Solar Activity of Department of Development . . . . . . . . . A-19

NEW YORK AB 8620

Recommended Budget for $1976-77$. . . . . . . . . . . . A-20

SOUTH DAKOTA SB 283

SD Rev PT 8 9-75, "Claim for Solar Heating and Cooling Allowance" . . A-22 

Nime (owner)

Matilingr

Address

City phone Res. State Phone Bus.

Property address or location:

\section{INFORMATION}

Auswer all questions - attach necessary supporling documents - indicate reasons where information is not furnished.
2. Description of system (sce insl.ructions)

3. Type of property

New Remodel

Cost included in purchase price?

Yes No

If yes, how much?

1. Arquisition of Solar Heating or Cooling Devices Date purchased

Total cost or purchase price including installation $\$$

Seller's name and address

I, owner or agent of this property, state that the information and facts constitute true and complete statements concerning the described property. I agree to furnish additional information requested by the Assessor.

\section{Signature}

Name of builder or contractor

\section{Date}

DO NOT USE -- FOR ASSESSOR ONLY

Was physical review made by appraisal staff?

Yes No

What other heating or cooling devices in this improvement?

Statement of appraiser's findings and recommendations:

Appraiser's estimate of actual value: $\$$ Assessed Valuation $5 \% \$$ BY Da te 


\section{INSTRUCTIONS}

\section{For completion of form "Solar Heating and Cooling Devices"}

1973 Colorado Revised Statute 39-1-104(1) requires the assessed value of all improvements to be $30 \%$ of actual value.

1973 Colorado Revised Statute 39-1-104 (6) provides an exception as follows.

The valuation for assessment of all solar heating or cooling devices attached to or a part of any building improvement shall be at an amount equal to five percent of the actual value thereof as determined by the assessor in accordance with the regulations of the property tax administrator. For the purposes of this subsection (6), solar heating, solar hot water, or solar cooling devices shall include all controls, tanks, pumps, heat exchangers, and other hardware necessary to effect the installation of a solar heating or cooling system. Solar heating or cooling devices shall not include walls or roofs unless those portions of the structure shall be a part of those devices specifically designed into the system to provide additional heating or cooling that would not ordinarily be contained in a structure not designed or modified to provide solar heating or cooling.

1973 Colorado Revised Statute 39-5-105 requires owner of solar devices make application for separate appraisal and valuation.

In appraising and valuing improvements any device which is attached to a building or structure or which is an integral part of such structure and is designed to provide solar heating or cooling shall be appraised and valued separately from such building or structure. Such separate appraisal and valuation shall be made upon application of the owner of the improvement to the assessor.

The attached form may be used as an application and provides spaces for listing pertinent information. The second copy is for your records.

Enter the name, mailing address, and phone number of the owner. Identify the property by address or location. ALL QUESTIONS MUST BE ANSWERED. Failure to do so may result in a denial. Indicate reasons such as "not applicable", "unknown", etc. where information is not furnished.

1. Enter the date purchased, the total cost or purchase price, and the seller's name and address. Also list the date of construction and the name of the builder, or contractor.

2. Describe all parts of system such as controls, tanks, pumps, collectors, duct work and other hardware necessary to make the system operable.

3. Indicate if the property is new or remodeled and what amount of the purchase price, if any is attributable to solar devices.

Application form must be signed and dated by the owner or agent of the property. 


\section{APPLICATION FOR VALUATION UNDER SECTION 20d-3 \\ OF THE REVENUE ACT OF 1939 RELATIVE TO SOLAR ENERGY HEATING OR COOLING SYSTEMS}

T0: Supervisor of Assessments, County Assessor or Board of Assessors.

County.

Township

1. The undersigned , being the person liable for taxes on certain real property hereinafter described, hereby requests that the said real property be valued for the assessment year January 1,19 the Revenue Act of 1939, as amended.

2. Legal Description and Index Number as shown on tax bill. (Use reverse side if necessary)

3. The undersigned states that he (she) is the owner of the above described property; that improvement(s) thereon are equipped with a solar energy system used for (Heating) (Cooling) (Heating and Cooling) ; and that the total cost of installing such system was $\$$

4. The undersigned understands that when the solar heating or cooling system so valued ceases to be used as a means of heating or cooling the improvement(s), the owner of the real property must, within 30 days, notify the Supervisor of Assessments, County Assessor or Board of Assessors, as the case may be of that fact; and that it is a Class $B$ misdemeanor to fail to submit such information or to knowingly submit any false information in or relating to this application.

Applicant

Applicant's Address

Date: 19 A. D.

Subscribed and sworn to before me this day of 19 A. D. 
FORM SES-1 1975

PRESCRIBED BY THE STATE

BOARD OF TP.X COMMISSIONERS
Original (County Auditor)

Duplicate (Mail to State Board

of Tax Commissioners)

\section{STATEMENT FOR DEDUCTION OF ASSESSED VALUATION ATTRIBUTED TO SOLAR ENERGY SYSTEM \\ (Pursuant to Acts 1974, PL 15, IC 1971 6-1-9.5) \\ To Be Filed in Duplicate with the County Auditor \\ (of the county in which subject property is located) \\ Between March 1 and May 10, inclusive each year By the owner of such real property}

STATE OF INDIANA COUNTY, ss :

I, (We), certify that $I$, (We) on

the lst day of March, 19 , owned the following described real

property which is equipped with a solar energy heating or cooling system for which a deduction from the assessed valuation is hereby being applied.

PROPERTY DESCRIPTION

TAXING DISTRICT (CITY, TOWN, TOWNSHIP)

LOCATED IN TOWNSHIP LEGAL DESCRIPTION OR KEY NUMBER

1. ASSESSED VALUATION OF IMPROVEMENT INCLUDING SOLAR HEATING OR COOLING SYSTEM \$

2. MINUS: ASSESSED VALUATION OF IMPROVEMENT WITHOUT THE SOLAR SYSTEM

3. DIFFERENCE

DEDUCTION ALLOWABLE

4. LESSER OF LIINE j ÁBOVE OR \$2, Ũú

\section{$\$$}

I hereby certify the above statement to the best of my knowledge is true, correct and complete.

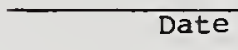

Date

Signature of owner

\section{Address of owner}

\section{City and State}

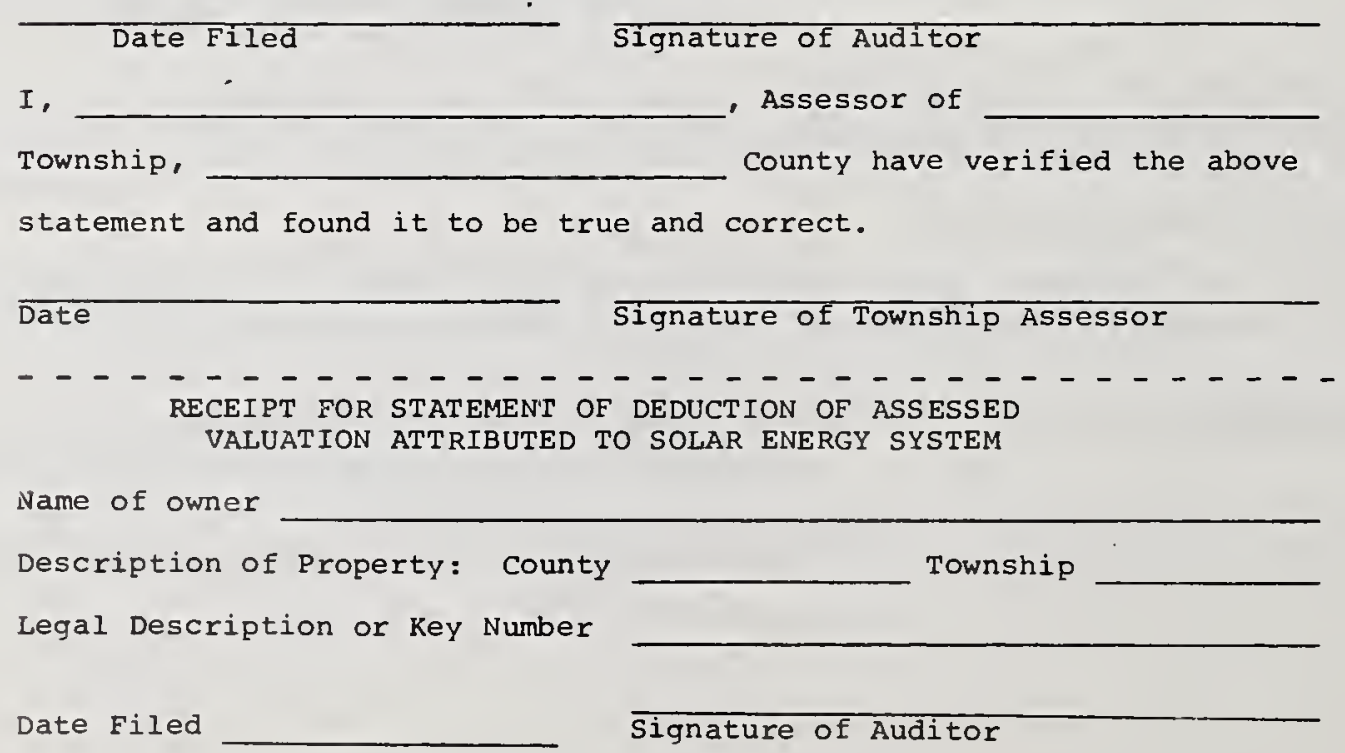




\section{GUIDELINES FOR PREPARATION OF PROPOSALS}

TO THE IOWA ENERGY POLICY COUNCIL

Proposals for energy research and development to be funded in Fiscal Year 1976 are due at the Iowa Energy Policy Council, 300 Fourth Street, Des Moines, Iowa 50319, by April 1, 1976. The EPC is interested in proposals that involve Iowa uses and resources, that do not duplicate work being tried elsewhere, that might attract matching federal and private funds, and whose results could be developed and used fairly rapidly and might foster the development of new industry in Iowa.

The Council has expressed particular interest in certain specific areas: resource recovery; utility rate experiments; utility wind energy demonstrations; energy conservation projects, including those directed at community betterment; and providing funds to buy materials for solar systems to be built and installed by students in training programs. However, the Council will not restrict proposals to these areas, nor will it make awards in these areas if worthy proposals are not forthcoming.

All proposals should be specific and, as a minimum, include the information set forth below:

1. Name and address of the person(s) and/or organization(s) submitting the proposal.

2. Date of submission.

3. The specific objectives of the project, including the applicability of the project to Iowa and the beneficial results to be expected if the project is successful.

4. An outline and discussion of the project, including the period of time involved and the dates of completion of the various stages of the project.

5. The amount of funds required, together with an itemized breakdown of the costs of the project: equipment and instruments (including transportation and installation costs), expendable supplies, services (such as computer rental or chemical analyses), salaries and wages, indirect costs, secretarial expenses, travel, and miscellaneous. Indicate what other sources of funds are or might be available to assist in the project. Costsharing would be welcomed so that EPC funds could cover more projects.

6. Names and addresses of key personnel to be involved, together with brief biographical information and relevant experience.

The EPC would appreciate receiving 20 copies of each proposal; however, this is not a mandatory requirement.

Proposals received by the EPC will be evaluated by a panel of reviewers, who will be asked to comment on the technical merit of the proposal, the competence of the investigators, the reasonableness of the budget, and the importance of the project to Iowa. Ratings will be requested on a five-point scale: $4=$ excellent, $3=$ good, $2=$ supportable, $1=$ poor, $0=$ unsound. The anonymity of the reviewers will be strictly maintained, but extracts of their comments will be passed on to members of the EPC and will be discussed at a public meeting of the EPC. These comments will also be passed on to applicants without identifying the reviewers.

At a public meeting the EPC staff will provide the EPC members with the reviewers' comments. The choice of the proposals to be funded will be made at a public meeting, probably in June, by the members of the EPC, who may discuss some or all of the proposals in public. Proposals chosen for funding will be made public, but submitters of all proposals should note that portions of their proposals may become public in the course of the EPC meeting at which they are discussed. For this reason submitters may wish to avoid including proprietary information or other information which they do not want to be made public.

In accepting an EPC grant, the applicant must agree to provide a final report within one month of the termination date of the grant. The final report must account for the expenditure of the funds and describe the accomplishments of the research project. 
sub-chapter is

Alternative Kencwable Energy source Grants

section $36-2.3(13)-55060$

$36-2.8(3.8)-53070$

$36-2.8(18)-58080$

$36-2.8(18)-58090$

$36-2.8(1.8)-58100$

$36-2.8(28)-58110$

$36-2.8(28)-58120$

$36-2.8(18)-58130$

$36-2.8(18)-58240$

$36-2.8(18)-58150$

$36-2.8(18)-58160$

$30 \cdots 3.1 \pi$
DUPOSE OP KULES

DITINTTIONS

SIMTEMENT OF TDMINISTREIVE PUIOCIES

IIPPLTCATIONS - - GENERAL REQUIREMENTS

APILICATION CONTENT

ARILICFTION SUBMITTAL DEAD1,IMTS

RPFLICATION EVALUATICN

ATSARDING GRINTS-CRITEZIIS

CUNDITIONS JNDER HHJCH

GRNITS MAY IE USED AIVD OTHER

CONLITIOANS

FIYAEN OF GRANTS

PROSECT AIN:INJSTRATION

WONTRAA ADPINISTRATIVE CONE 
sub-chaptor 18

Bj.ternative konewable Inergy souxce Grants

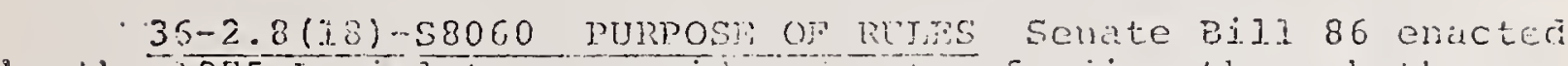
by the 1975 Legis]ature provides of the funding through tho

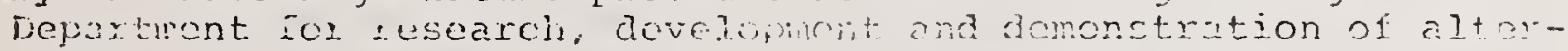
native renewable energy sourcos;. The furpose of the rules in. this sub-chupter is to provide criterin aud guidelines to aid in the implementation of that law. (History: Sec. 84-7410, R.C.M. 1947; INIS, MAC Not. No. 36-2-5; Order MAC No. 36-2-9; Adp. 2/6/76; ErE. 3/7/76.)

$36-2.8(18)-38070$ DEFINTITO2IS Unless the context recuires otherwise, as lised in the $\lambda$ ct and in the rules in this subchapter:

(1) "Act:" means Chapter iro. 501, Montana Session Isaws of 1975 (also refexred to as the "Rlternative Renewable Energy Sources Act": Scetion 34-7407 ct sea. , R.C.M. 1947).

(2) "Alternative ienewabe nergy source", as definod in section 84-74is(i) of the .ct, means a form of energy or matto: such as solur encicgy, wind encygy, or mothane from solid viaste, capabje of bejng converted into forms of cmergy uscful to menkind, and the lechrolory nocessery to melo this comversion, whon the source is not cxhaustible in terms of this piantet and when the source or the terhnojogy are not in enceral conmercial usn.

(3) "Ierion" means a natural person, coxporation, pert-

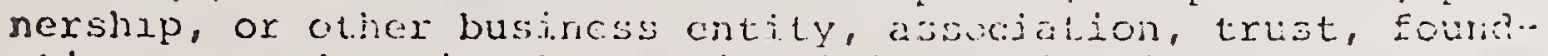
ation, any cducitional or scientific institution, or any governmental unit. 
$36-2.8(18)-58070$

NingINi,

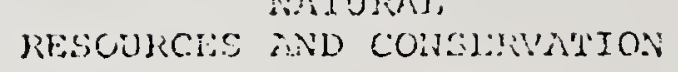

(4) "Dopartment" mans the Depastrent: of Natural Resourcess and Conservation.

(5) "Applicaijon" neans a written application to the Departinent for funding uncer the tesms of tic $\lambda c t$ and these rujes.

(6) "Rescarch" means an extensive, systematic study" to discover or revisice facts or theories and which roule brine to a more advance? state the capabilities, availability and suitubility of a rencwable allernative energy source.

(7) "Develop" or "develoment" means a project wihieh utilizes the basic results of rescarch or available knowlecige and applias those result: or knowlecice to the actual devejopinent of hardware. The terin also includes the cstablishment of nanufacturing facilitjes to producc rencwable alternative crexcy systchs in liontan, but it docs not include the development of a project or facjlity to comercialiy market clectricity, heat energy, or cuergy wy-products.

(8) "Dchonstrate" or "cemonstration" means an extensive, systenatic plan aisc follow through to cstablish that specific rencwable alternative cnergy sovices are prictical ana cas ie Inacie to work reliably over long perioc?s of time. These projects arc primarjly physical models which will be proven. (History: Sec. 84-7410, R.C.l1. 1947; NEW, Nj:C Not. No. 36-2-5; Order M. No. $36-2-9 ;$ Adp. $2 / 6 / 76 ;$ Eff. $3 / 7 / 76$.

\section{6-2.8(18)-S90S0 STRTEMINTT OF ADMTIISTRAIIVE POIICTES}

(1) It is the ol jective of the Department to orjent the maing program tovird the small scale, incijvidual, single unit dweling iype of applicition. Larce sacle, capital intensive project. appljections, lill be accepted, but the program emphasis will be dirceted tovard the aforcmentionce type of applications.

(2) It is the objective of the Departrient to give iundins preference to development and demonstration projects.

(3) It is the jntent of the Departilent to only grant funding for applications wich are submitted by persons wio are residents of ihe stijto of Montana, and nrily for projects conciust-

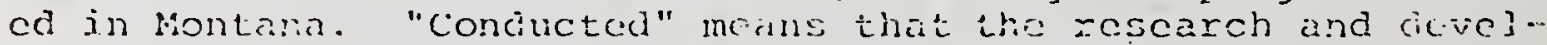
opment project will be headeusetered in yontana and that is? devejophent will dio juilt in lontrina. This conditjon does rot prohibit the vese of cynertjse outsicie the state of Hontan.

(1) Iersons who are cmployecs or contractors of the bepartment, or who are members; oi the Bourd of Natural resourecs and Conservation, are not cligjtice for fmaing under the sct. Rolitives rolated to such person by consunguinity within the fourth degree or by affinity rithin the sccond degrec are like- 


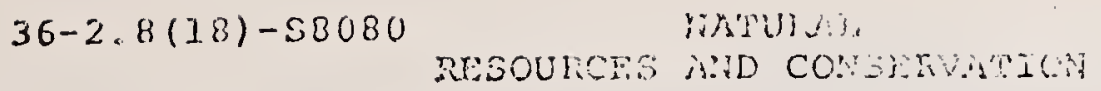

wise not eligible for funcincs.

(5) Applications tin riscureh, cevelop, or comonstrate

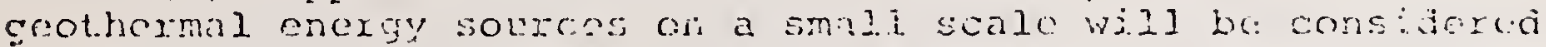
for funding. Large scale, capital interseive projects are not eligible for funding.

(6) Scme types of renewabie alternative energy sources; (e.g., solar and wind) axc unable to prociuce cnerejy or a continuous basis, therefore epplicalious for stueiying encrgy storage devices associated with such renewale energy sonecs wil be acuepted.

(7) As a gencral rule applications for nore ihan 3100,000 wiJ.? not be granted. However, the bepartment wizi accopi and review applications for more than $\$ 100,000$. If the Department jotermines that such a proposal is particularly applicable to rontana's energy neers and technically outstanding, it may be funded. There is no lower limit for funding.

(B) The Department will apoint an $\lambda$ itemative Energy

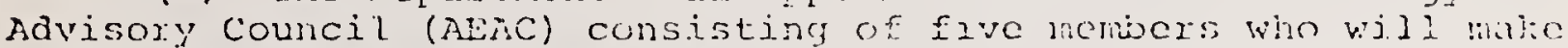
recommendations on which applications should be iunded. The Departmont makes the final decision as to which appijcations aro fundied.

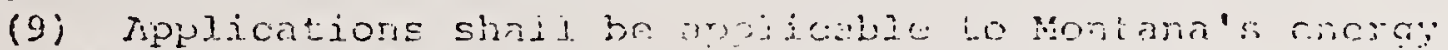
needs. If the technology is not tursitle as sulbed to the nects of Montana, the application will not be gianted.

(10) The pepartment may func all or cily past of a proposal. Gencrally, only an aplicaticn which is directly relateci to the rescarch, development, or cononstration or alternative

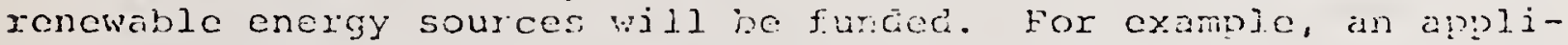
cation to build a $\$ 50,000$ solar home may not be funded in illi, but an application to domonstrate iew solur techiology as part of a hoire may be funcied. (Histofy: Sec. 84-7410, R.C.A. I9.i7; NEEN, HAC Not. No. 36-2-5; Order MNC No. 36-2-9; iscip. 2/6/76; Eff. 3/7/76.)

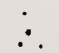

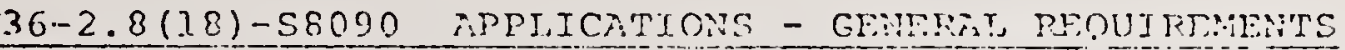

(1) Any person ma miate aplication for a grant to ind a proposal under the Act and these rules. The applicant should normally submit ton copies of the application at the tinc of filing to the inergy pinnning Divjsion of the Department, ?z South Eving, Helena, irontana, 5900l, coisistont vith thess rulcs. A insscx number ni copies may be submituce upon pricr approvai of the Depaxtinent. 
$36-2.8(15)-58020$

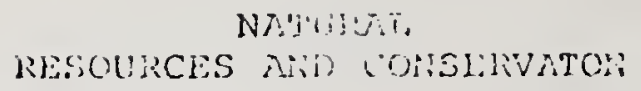

(2) Fi) though met renujed, to farijitato wnifornity the application shoul neet the following rouviroments:

(a) The apdication should bo typed, printed, ox other-

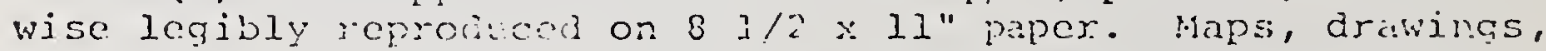
chats, or other docunenis boura in an application should be cut or fold d $: 03 \mathrm{l} / 2 \times 1 \mathrm{l}^{\prime \prime} \mathrm{s} ; \mathrm{ac}$. Maps, drawings, or chares may accoripany an application as scparate exhibits.

(b) "yped or nffset matcrial should have a l" margin on all siles.

(c) All pages in an appljiction should be consceutjucly numbercd. Mays, drawings, ot chirts accompanying the a! plicalion as arhibits should be juontifica as "Exhibit " and if comprising move than one shect should be numerea isheet of

(3) The application snal? state the name, titie, telephone number, and post office atiress o: the person to whom communication in reaira to the applicaion shoula be macie.

(i) I'le jopartment wijl review the application to determine whether it is in substantial. complinnce with the fiet and these rules. If the Departmont determines that the apilication

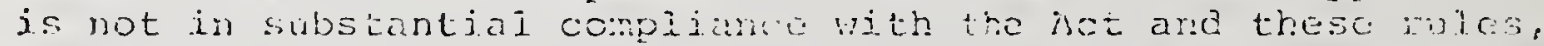
the application will be consiriaed defizient and the Departrent will reject the application; notifying the applicant in witing and ljsting the application deficiencies. The upplication may be re-sulmitted after corrections are made.

(5) The applicant shoujd subinit sipplomental matcrial upon request or when it becones availabie witrout undue delisy after an application is files to update dxarings and information submitted with the original apilication.

(6) If an applicant desires to change or add to an apoication, after it is forl ally fjled, the applicant shall inforn the Departricnt in witing as scon as posidble of the charese or addition. If the change or adcition bill result in a subsitantial change in the amount of funding recruested or the goals and objectives stated in the origjnal application, the Department will consider the change or addition to constitute a new application.

(7) There is no form acopted by the Department to fili

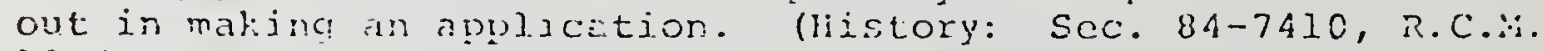

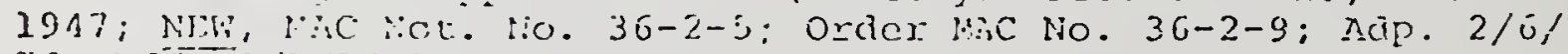
76 ; EST. 3/i/76.)

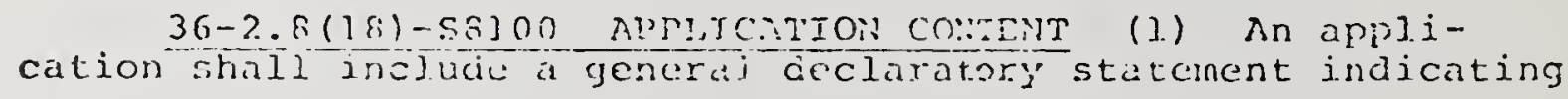


$36-2.8(18) \cdot \cdot 58100$

INR:-1:2:1,

RLSOULCES TAB COMERVATON

whether the aplicent is seeking funts for a resenceh, development, or demontitration project.

(2) The apoljeation shill incluoe a declaration of the type of rencwable alternative energy source to be studied (i.c., wind, solar, watcr, etc.).

(3) The application should contisn a revico of the existing "state of the art" conducted by the applicint in the area of inierest.

- (4) The application should incluae, whenever applicable, a description of the proposal, including, but not limited to:

(a) $A$ theoretical basis; for the proposal including all pertinent maps, diagrams, and photograns;

(b) The proposcd techroiogy incluaing all pertincnt diagrams and photographs;

(c) The proposca rescarch nethods and construction methods if constuction is a factor, plus all pertinent maps, diagrams, and photographs;

(d) The propesed facizitics and equipment necded, including physical dimensions, diagrans, and photographs;

(c) Ihe proposced time schecule for project cevelopment;

(f) $\lambda$ description of the reonosnd anticifated icsidts.

both practical and thcoretical;

(g) A statement as to how the project can advance the state of the art;

(h) A statement indicating where the project will be constructed, and why that particular site is suited to the proposed project;

(i) A statcment indiciting who will work on the project, and what their various qualifications are;

(j) $\lambda$ statement of the role of the project in meeting future encrgy needs;

(k) $\lambda$ statement of how the project will be feasible and applicable;

(1) $\Lambda$ statement of the project's environmental compatibility, especially:

(i) Pollutants or contaminants produced;

(ij) An cotimites of the net crorey yiold of the proficet.

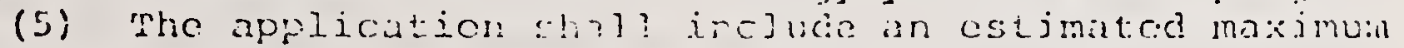

budget which nuy not be cyccedeci, which shoule contain:

(a) The wages and sajnrins of ali rescarch personncl,

clericas loolp, crafismen, ote. (itemizd);

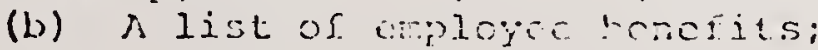

(c) $\lambda$ Iist of building costs;

$36-34.3 .50$

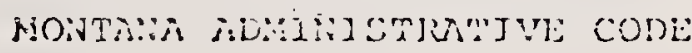


$36-2.8(18)-58100$

MiUnd.

RESUURCES RUD CONSERVAIICA

(c) I list of equiprert costs (equipment generally are permancret items);

(c) A list of acmisistrative and overhead costs;

(f) $\lambda$ list of the cost of supplies (supplies generaliy are exhaustible: it(ons);

(g) A list of comnanication and travel costs;

(h) $\lambda$ list of any other: cxpenses.

(6) 'lhe application should cortain a copy of all contracted or sub-contracied work, including budgets, who is to co the work, and what work is to be che. If these are not available at the time of appication, they shall be submicted at: trie time they become available. (History: Sec. 84-7410, R.C.if. 1947; NEW, MAC liot. No. 36-2-5; Crder NinC No. 36-2-9; Adp. 2/6/ 76; Erf. 3/7/76.)

36-2.8(1.8)-58110 APPIICATION SURYITTAL DFADIINES FOr the remainder oi iscal year jy cations may be subnitled to the Department until May 1, 1976. Thereafter, for each subscruent fiscal ycur, applications nay be submittca from January l throush March 3l. (History: Sec. $34-$ 7410, R.C.H, 1947; NUt, HC ICt. No. 36-2-5; Order MAC No. 36-29; $\operatorname{dp} .2 / 6 / 76 ;$ iff. $3 / 7 / 76$.)

36-2.8(18)-SE120 APPIICNTJON EVALUATION (1) In general, applications wj. 1 be revieved and ovaluated by members of an adhoc committce which will be cstablished by the Department. These member:; will bo cualified technical peopie in their respective renewable altornative energy ficlas. They may or may not ve residents of the state of Montana. The Evaluations wil be done on an anonymous and confjdential basis and the rosults will be discjosed to the applicant upon request.

(2) The niternative Energy Advisory Council (AEAC) will reet after the reviews and evaluations are completed to discuss cach application and make recolimendations to the Dcpartmer..

(3) Due to the finite amount of funds available curing each evaluation and grant period, applications recoived for consideration at that time will be compared for reiative nerit ar; woll as individual merit. The Departinent will then decide vhich applications to func. (listory: Scc. $34-7410$, R. L.

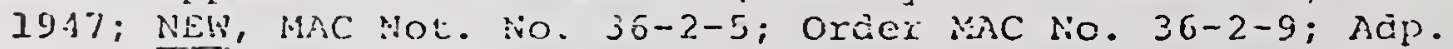
2/6/76; Fif. 3/7/70.)

$$
36-2.8(13)-58130 \text { AWRTIi: GRNAMS - CRITFRIA (1) A }
$$
grant awarace by the bipartinent may cover a period not excecding one (1) yeir, and the Depertment may not by law commit itsclf to spending funds articipated to be available more lhan

$36-14.15 \mathrm{~F}$ 
ore (1) year after the grant period besins, whe Departinent may, however, issue lecters of incent to rencw projects which require nore than one yoar for completion if in the opinion of the Department, the first year of work is successful and achieves the goals established by the oxiginal applicetion. Applications for renowal will be evaluated in the normal evaluation manner and must compto vith now applications for funding.

(2) The Department may give preferenee to researeh centers unatached to existing educátional institutions where several investigators can shere supporing serviecs. However, this: shald. not be interpreico to pronibit the Department from awarding grants to existing edueational institutions or individuals.

(3) If a manufacturing project defineo under the development type of appliciction is successiul, the applicant may be required to repay the Deparment all or part of the funds aranted.

(1) By law, all infolnation resulting from research, development, or demonstration projects funded by the Department under the fo: and these rules sholl be made available to the public and maty not become the irivete properly oi or uncies the exclusive control of any ore company or person.

(5) The Department ifs under no requirement to expend or commit available alternative rencwable energy research, devejopment and demonstration furrs when in its judgment such expenditures or commitments would be unproductive. (IIjstory: See. E4-7410, R.C.H. 194\%; NEN, MAC Not. No. 36-2-5; Order MAC No. 36-2-9; Adp. 2/6/76; ETE. 3/7/76.)

36-2.8 (18)-S8140 CONJTTONS UNDER WHICH GRNMS MAY ETE

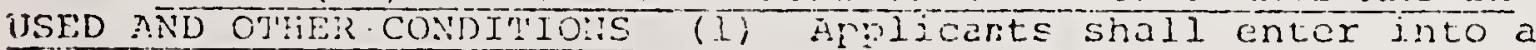
contraci grant agrecment with the Department if funded, under such terms and conditions the Departinent considers appropriate. If the recipient fecls that changes in the contract are necessary at some later date, then those changes shall be negojated with the Department. If a satisfactory agreoment carnot br reached the eontract and the furiding may be teminated by the Department.

(2) Grant rocipicrte shall subnit periodic progress reports as specified by the beparcncit, and shall submit final reports to the Department iritiin tirec (3) months following the yearly grant period. 
(3) Grant recipients shall subnit an itcaizer jist oE expenses with oecir montiny or grartrily billing for paymont.

(4) Grant recipients shall male oral or witten presentations of presress if reguested to do so by tic Depratement.

(5) Funds granted under the tesms of the het ind tirese rujes may be used on]y for the plirposes out?ince and descidied in the applicition and approvec iy tro popatement, and detalled records shall be kept by the recipjent for all expendicures. since the proposal bucigets are injtially estimated, some transfers up to $25 \%$ among the sujget categoites expenditures will be ailowed.

(6) The grant recipient shan? maintain an accounting system which adequately accounts for cxpenditures in a manner acceptable to the Departinent. Records, cxpenditures, bookkeening, etc. for funded projects are subject to audit by the office of the Jegislative lubitor and the Department.

(7) Arrangonents shaii le made to assist, gujde and inform the Department during on site investigations. The Department will make such investigations at its discretion. (History: SCC. $81-7410$, R.C.M. 1947; NE. WAC Not. 110. 36-2-5; Order liAC No. 36-2-9; ide. 2/6/76; Ef $3 / 7 / 76$. !

$36-2.8(3.8)-58150$ PAYMENT OF GRENTS (1) UpOn approval of an application by the bepurtment, fuis will be set aside for that particular project.

(2) layments shall be made on a monthly or quarterly basis against the balance of a given application's funds, upon. a request for payment by the recipjent.

(3) Paynents vill be made onjy on valid project reiated expendjturcs, and any balance of payment mace at the end of tre onc year's funding period shall be returned to the Depaitmont. (History: SCC. 84-7410, R.C.M. 1947; NEV, MIC Not. No. 36-2-5; Order UAC No. $36-2-9$; AdP. $2 / 6 / 76$; Ef: $3 / 7 / 76$.

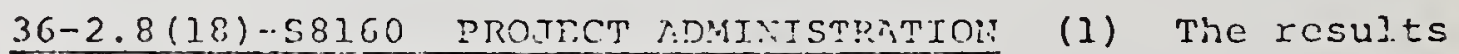
of all rescarch, development or cenonstration projects shall be made public record.

(2) poisons receiving demonstration funas may bo required to make their jrojects opan te the public during reasoratie hours for a periec of time specialice ijy the Department.

(3) Jic Defartment may inspeci ane monitev all projects on a regular basis after comilecion of the project.

(4) The appjjeart may be required to maintain his zunico project durinc the monitoring peidod. Illistory: Sec. $84-7 i 10$, K.C.H. 1947; N.il, MAC not. i0. 36-2-5; Orcer MAC No. 36-2-9; Adp. 2/6/76; E: $3 / 7 / 76$.)

$36-11.15 G$

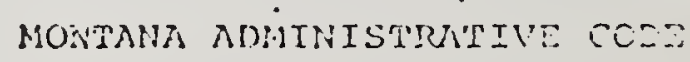


APPLICATION FOR CLASS 8 ASSESSMENT OF THE INCREMENTAL INCREASE IN VALUE ATTRIBUTABLE TO A CAPITAL INVESTMENT FOR AN ENERGY CONSERVATION PURPOSE IN THE BELOW DESCRIBED PROPERTY IN COMPLIANCE WITH CH. NO. 548, LAWS OF 1975. IF APPROVED, THE INCREMENTAL INCREASE in VAlUe WILL Be ASSESSED IN THE $15 \%$ CLASSIFICATION.

COUNTY

SCHOOL DISTRICT

A RESIDENTIAL — COMMERCIAL BUILDING OR MOBILE HOME LOCATED ON LAND LEGALLY DESCRIBED AS . INDUSTRIAL , FARM

HAS HAD THE FOLLOWING WORK DONE TO IT FOR ENERGY CONSERVATION PURPOSES:

THE ABOVE CAPITAL INVESTMENT HAS INCREASED THE MARKET VALUE OF THE BUILDING IN THE AMOUNT OF \$

SIGNATURE OF APPLICANT DATE

ADDRESS

\section{FOR THE COUNTY APPRAISER}

APPLICATION RECEIVED ON THIS DATE

REAPPRAISED

CLASS 4 FULL VALÜE $\$$

DATE

CLASS 8 FULL VALUE $\$$

REMARKS:

NOT ICE

THIS APPLICATION MUST BE COMPLETED AND SUBMITTED TO THE COUNTY APPRAISEF BEFORE THE FIRST DAY OF JANUARY.

FOR THE DEPARTMENT OF REVENUE

APPLICATION FOR CLASS 8 ASSESSMENT HAS BEEN APPROVED DENIED

REMARKS: 


\author{
STATE OF MONTANA \\ DEPARTMENT OF REVENUE
}

\title{
APPLICATION FOR TAX INCENTIVE ASSESSMENT OF \\ ENERGY GENERATING PROPERTY
}

TO BE APPLIED TO THE APPRAISED VALUE OF CAPITAL INVESTMENTS IN RECOGNIZED NON-FOSSIL FORMS OF ENERGY GENERATION AS PROVIDED IN SECTION 84-7401-7406. NOTE - THIS APPLICATION MUST BE COMPLETED AND SUBMITTED TO THE PROPERTY VALUATION DIVISION, DEPARTMENT OF REVENUE, HELENA, MONTANA BEFORE THE FIRST DAY OF APRIL.

$+20$

COUNTY DATE

NAME OF APPLICANT

ADDRESS

I/WE ASK TAX TREATMENT ALLOWED UNDER THE ABOVE ACT FOR THE FOLLOWING INSTALLATIONS (GIVE BRIEF DESCRIPTION) :

LOCATED ON LAND LEGALLY DESCRIBED AS

THE ENERGY GENERATING FACILITIES WERE INSTALLED AT AN ESTIMATED COST OF BETWEEN THE FOLLOWING DATES

AND

SIGNED BY OWNER OR AGENT.

(ATTACH ADDITIONAL SHEETS IF MORE SPACE IS REQUIRED) 
Under House Bill 663, passed by the 44th Legislature and signed into law, certain tax advantages are given to improvements in property which help conserve energy, as well as for recognized nonfossil forms of energy generation. The new law took effect January 1, 1975, and covers any improvements or installations undertaken after that date

The purpose of the act was to encourage the use of alternative energy sources and the conservation of energy through incentive programs. These incentives will be made avalable to the energy user on a basis requiring him to take the initiative in obtainıng a parficular incentive.

\section{PROPERTY IMPROVEMENTS THAT CONSERVE ENERGY}

Any capital investment made in Im. provements to buildings or land for energy conservation purposes falls under the act. A designation of Class 8 (rather than Class 4) will be given to whatever amount the improvements increased the appraised val. ve, up to 20 per cent of the property's valuation.

This applies to any building (including a mobile home), whether the building is used for domestic, commercial, industrial or agricultural purposes. The capital investment can be any material or equipment purchased and installed in the building or on the land, with or without improvements.

Investment for an energy conservation purpose is defined as any investment resulting in the reduction of waste or dis sipation of energy, or the reduction of the amount of energy required to accomplish a given quantity of work.

\section{HOW TO APPLY FOR THE} PROPERTY TAX REDUCTION

The property owner of record (or his agenr) must make application for assess. ment, in the Class 8 classification, of the increase in property valuation attributable to a capital investment for an energy con. servation purpose. Application forms will be available in the office of the County Appraiser

The taxpayer must complete his portion of the form and return it to the Appraiser who will, upon investigation, decide if reappraisal of the property is necessaiy If found necessary, the appraisal will be made from the cost manual used for similar property in the area. He will estimate the amount of the increase in value attributable to the capital investment for energy conservation purposes, and show the amount as a separate figure on his property record card.
The Department of Revenue will subsequently approve or deny the application for Class 8 assessment and refurn the application form to the County Appraiser. If the application is approved, the Appraiser will notify the taxpayer of the new values, showing separately the portion of the full value to be assessed in Class 4 and the portion of the full value to be assessed in Class 8

\section{RECOGNIZED FORMS OF NONFOSSIL} ENERGY GENERATION

Any capital investment by the taxpayer in a recognized nonfossil form of energy generation will be treated by the Department of Revenue as property exempt from taxation, to the extent the appraised value of the investment does not exceed $\$ 100$, 000 , and Class 7 property for any portion of the appraised value of the investment that exceeds $\$ 100,000$.

This covers qualified systems for the utilization of solar heat, wind, solid wastes, or the decomposition of organic wastes, for capturing energy or converting energy sources into usable sources, and for the production of electric power from solid wood wastes. It also covers any small system for the utilization of water power by means of an impoundment not over twenty $(20)$ acres in surface area.

Energy generation tax advantages are limited to persons and firms not primarily engaged in the provision of gas or electric. ity derived from fossil fuel extraction or conventional hydroelectric development; and a ceiling has been set of $\$ 100,000$ in tax savings per year to any one person or firm.

Application forms for the tax advantages to nonfossil energy generation are avail. able from the Department of Revenue. It should be noted that these applications may be reviewed by the Montana Department of Natural Resources and Conser. vation

Further information and appropriate forms are available from the

Property Assessment Division

Montana Department of Revenue

Sam W. Mirchell Building

Helena, Mt. 59601

PAID FOR BY THE MONTANA DEPT OF NATURAL RESOURCES ANO CONSERVATION IJNOER SB 86. 


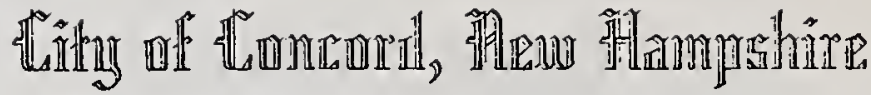

ASSESSING DEPARTMENT

CITY HALL • 41 GREEN STREET • 0330 ?

\section{SOLAR ENERGY SYSTEMS EXEMPTION CLAIM}

1976

THIS APPLICATION MUST BE SIGNED AND FILED WITH THE ASSESSORS

ON OR BEFORE APRIL 15, 1976

I, the undersigned, herewith make application for real estate exemption on solar energy heating or cooling system in accordance with the provisions of Laws of the State of New Hampshire, RSA 72:62, as inserted by Chapter 391, Laws of 1975, and adopted by the City of Concord on November 4, 1975.

I certify that I am the owner of real estate located at

in the City of Concord, in which solar system has been installed.

Year of installation:

Name of manufacturer of solar system:

Name and address of contractor (builder) who installed system:

Owner's statement of cost of installation of solar energy heating or cooling system:

Type of property in which system has been installed:

(Residential, Commercial, Industrial or Public Utility)

1 , under the penalties of perjury do hereby declare that, to the best of my knowledge and belief, the above statements are correct.

SIGNATURE

MAILING

ADDRESS 
Solar Activity of Department of Development

(Under S.B. 120, 1975)

A. Past Activities

(1.) Coordinated state exhibits (including operational equipment)

a. Solar Energy Industries Association Exposition, Apri I 1975, Washington, D. C.

b. International Solar Energy Society Congress $\varepsilon$ Exhibition, July-August, 1975, Los Angeles, Cal i fornia

c. Southwestern Legis lative Energy Conference, September 1975, Albuquerque, New Mexico

d. National Building Show, October i975, Chicago, ll linois

(2.) Developed audio-visual presentation ("Alternate Energy in New Mexico'l) for in-state and national use.

(3.) Published Solar Flair.

(4.) Sponsored "Solar Energy Financing Symposium", February 1976, Albuquerque, New Mexico.

B. Continuing Activities

(5.) Conduct on-going inventory of solar energy projects in New Mexico.

(6.) Solicit and promote commercial interest in broadening New Mexico's production of solar energy equipment, both in-state and nationwide.

(7.) Consult on a regional basis regarding the development of standardization of solar system and equipment efficiency and related matters tangent to consumer protection.

(8.) Consult with other New Mexico state agencies regarding their activities relating to solar energy (e.g.,

Bureau of Revenue, Envi ronmental Improvement Agency, Energy Resources Board).

(9.) Perform 1 iaison function between state government and state and federal programs, and local alternate energy organizations, manufacturers and individuals. 


\section{NEW YORK STATE ENERGY RESEARCH AND DEVELOPHENT AUTHORITY \\ RESEARCH IN NEWY ENEFGY TECHNOLOGIES COMIPATISLE WITH ENVIRONMENTAL AND SOCIAL GOALS}

Chapter 864 of the Laws of 1975 rcstructured the Atomic and Spacc Devclopment Authority into the Energy Rescarch and Devolopment duthority. The Act changed a mandate which previnusly emphosized concentration on nuclcar development and space activities into a policy that focuses on the development of alternate sources of ligh yicld. low cost encrey. The development of new cnergy technologics by this State agency will serve to expand existing energy sources and will enhance the State's efforts to encourage tilc location of industry and the crcation of jobs in lew York.

The research performed under auspices of the Authority is financed from a State first instance appropriation. This cost is reimbursed through a charge levied against the State's gas and electric companies in accordance with section 18-a of the Public Scrvice Law.

Projects arc sclectcd and developed with the aid of the Authority's Research Committce. The Committce is presently composed of the Cliairman of the Public Service Commission and rcpresentatives of the State's busincss and academic communities who are cxperts in the field of energy research.

From 1972 until it was restructurcd in 1975, the Atomic and Space Development Authority conducted research projects that emphasized aspects of eicctric

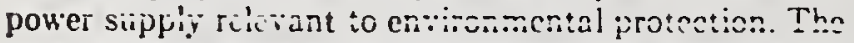
program was initiated in 1972 with a first instance appropriation of $\$ 500,000$ and in subsequent years was supported with a total of $\$ 5,890,000$ in additional appropriations.
Noteworthy result. have been achicved since inception of the Rescarch proram. For example:

- Through the Aithority's efforts, spray pond conling of waste heat from electric power plants was found to be feasible under conditions prevalent in New York Staie.

- The Authority and the Fcderal government havc jointly sponsor operations of a statewide seismic monitoring netrork, utilizing the Lamont-1)oherty Geological Lahoratory at Columbia Iniversity. Initial findings indicate a low spismic risk in selected test areas. Such findings are necessary for the siting of nuclear power plants.

- Significant adrances have occurred in lascr fusion research at the Lniversity of Rochcster. The cxamination of lever fusion as a potcntial source oi elcctric power is aided by a grant from the Authority's research funds. In addition, $\$ 7,500,000$ uas appropristcd in 1975 from the Capital Construction $F$ : $n d$, in the first instance. to support the construction of a laboratory facility at the University to sid this research.

Projects recommended for 1976-77 lave bcen rcgrouped into ner categories entitled Rcsearch. Dcrelopinent and $L$ imonstration. Rcsearch activities include lahoratoryor information eathering studies while Development activities involve fearibility analyses lcading to future car:ial projects and demonstration aetivitics may include the construction or modification of capital facilities.

Appropriated Recommcricd

\begin{tabular}{l} 
for $1975-76$ for $1976-77$ Change \\
$\$ 1,970,000 \quad \$ 6,390,000+\$ 4,420,000$ \\
\hline
\end{tabular}


1976-77

Recommended

\begin{tabular}{|c|c|c|}
\hline & \\
\hline & Amount & Change \\
\hline \multicolumn{3}{|l|}{ Research } \\
\hline Basic Research-Now Energy Technologies ...... & $\$ 600,000$ & $+\$ 350,000$ \\
\hline Energy Information system and Technology' & & +620000 \\
\hline Environmental Health and Safet $\mathrm{Rescarch}$ & 600,000 & $\begin{array}{r}+020,000 \\
+05000\end{array}$ \\
\hline Projects Completed or Discontinued .......... & UNo, & $-175,000$ \\
\hline \multicolumn{3}{|l|}{ Development } \\
\hline \multicolumn{3}{|l|}{ Integrated Fnergy Supply and Utilization } \\
\hline 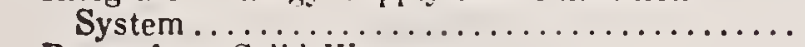 & 450,000 & $+325,000$ \\
\hline Power from Solid II astes........ & 300,000 & $+200,000$ \\
\hline Coal and Solid IVastc Gasification & 300,000 & $+275,000$ \\
\hline Laser Fusion Feasibility . . . . . . . . . . . . . . & 340,000 & \\
\hline $\begin{array}{l}\text { Utilization of Biocenversion Technologies ....... } \\
\text { Sulfur and Other Fucl Pollutant Extraction }\end{array}$ & 200,000 & $+200,000$ \\
\hline Technologies $\ldots \ldots \ldots \ldots \ldots \ldots \ldots \ldots \ldots$ & 100,000 & \\
\hline Projects Completed or Discontinued .......... & & $-100,000$ \\
\hline \multicolumn{3}{|l|}{ Demonstration } \\
\hline Solar Heating and Cooling .......... & $1,500,000$ & $+1,500,000$ \\
\hline \multirow{2}{*}{ 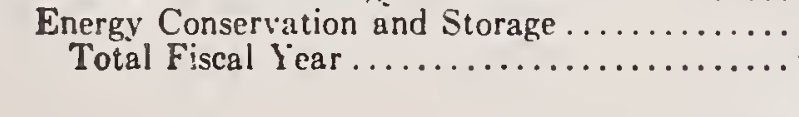 } & $\begin{array}{l}400,000 \\
800,000\end{array}$ & $\begin{array}{l}+400,000 \\
+800,000\end{array}$ \\
\hline & $\$ 6,390,000$ & $+\$ 4,420,000$ \\
\hline
\end{tabular}

STATE PURPOSES-FIRST INSTANCE

SUMMARY OF APPROPRIATIONS AND CHANGES 1976-77 RECOMMENDED

\begin{tabular}{|c|c|c|c|c|c|}
\hline \multicolumn{2}{|c|}{ Total } & \multicolumn{2}{|c|}{ Personal Servico } & \multicolumn{2}{|c|}{ Nonpersonsl Service } \\
\hline $\begin{array}{l}\text { Recom- } \\
\text { mended }\end{array}$ & Chenge & $\begin{array}{l}\text { Recon- } \\
\text { menaed }\end{array}$ & Chrego & $\begin{array}{l}\text { Recom- } \\
\text { mended }\end{array}$ & Chango \\
\hline$\$ 11,604,000$ & $-\$ 297,765$ & $\$ 3,302,000$ & $-\$ 47.765$ & $\$ 8,302,000$ & $-\$ 250.000$ \\
\hline
\end{tabular}

\section{STATE PURPOSES-FIRST INSTANCE}

SUMMARY OF PERSONAL SETVICE APPROPRIATIONS AND C?IIT:SES 1976-77 RECOMMENDED

\begin{tabular}{|c|c|c|c|}
\hline (a) & No. & Amount & Change \\
\hline 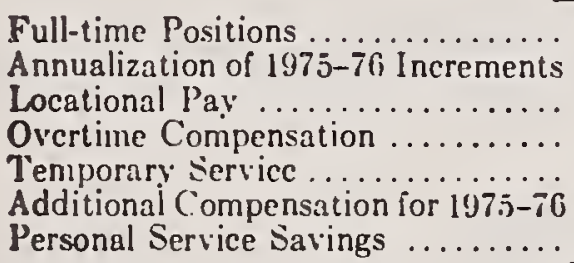 & 214 & $\begin{array}{r}\$ 3,158,780 \\
12,21 \frac{1}{4} \\
35,000 \\
5,000 \\
376,000 \\
\ldots \ldots \ldots 0\end{array}$ & $\begin{array}{r}+\$ 12,214 \\
-6,000 \\
+106,000 \\
\quad-40,250 \\
+92,271\end{array}$ \\
\hline Total ............ & 214 & $\$ 3,302,000$ & $-\$ 47,765$ \\
\hline
\end{tabular}




\section{CLAIM FOR SOLAR HEATING AND COOLING ALLOWANCE}

TO THE COUNTY AUDITOR COUNTY.

The undersigned being the owner of the within described real property certifies that he has attached or caused to be attached to such property which is used primarily for residential purposes, a solar heating or cooling system as the same is defined by SDCL 10-6-35.5.

\section{Description of property: Lot}

Plat or Addition
Block

\section{City of}

Claim is herewith made for the deduction allowed from the full and true value thereof by SDCL 10-6-35.6, for the current year.

I certify that the above statement has been examined by me and to the best of my knowledge and belief is a true and correct return.

Dated this day of 19

\section{Taxpayer must sign here}

\section{VERIFICATION BY ASSESSOR}

I certify that the full and true value of the above described property is as follows:

Full and true value with solar system. $\$$

Full and true value without solar system. $\$$

Net Difference. $\$$

Assessor, Director of Equalization

\section{ACTION BY THE COUNTY AUDITOR}

Pursuant to SDCL 10-6-35.7, the assessed valuation of the above described property will be reduced by the net difference certified by the Assessor or $\$ 2,000$, whichever is the lesser, converted to taxable value and entered on the current tax rolls as a reduction of taxable valuation in the amount of $S$

NOTE: File between November 1 and December 10

Original and one carbon to be filed with County Auditor 
APPENDIX B

STATE LEGISLATION

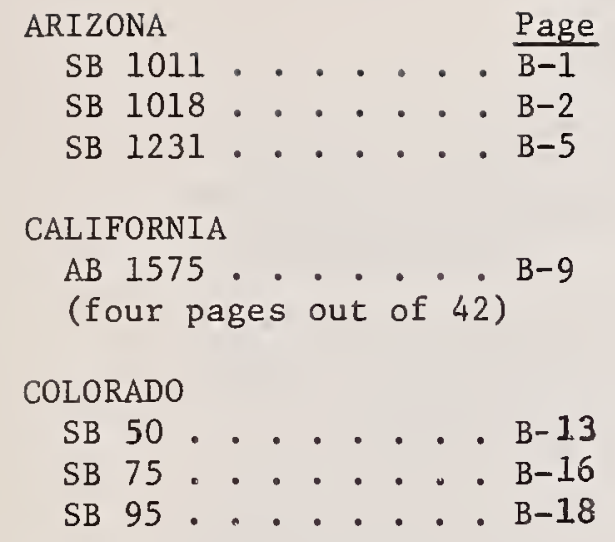

FLORIDA

SB 721 . . . . B-20

SB 158 . . . . B-21

HAWAII

SB 1586 . . . . B-22

ILLINOIS

HB 164 . . . . B-24

INDIANA

SB 223 . . . B -26

IOWA

SF 289 . . . . B-27

MAINE

SP 549 . . . . B- 29

MARYLAND

HB 1604 . . . . B-33

MICHIGAN

HR 129 . . . . B-35

MONTANA

$\mathrm{SB} 86 . .2 . .3-36$

HB 663 . . . . B-42

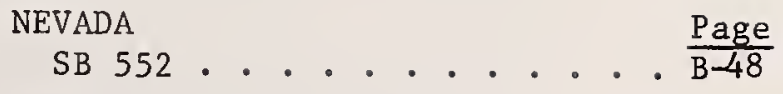

NEW HAMPSHIRE

НВ 479 . . . . . . . B-49

NEW MEXICO

SB 1 (Special Session) . . . B-51

SB 120 . . . . . . . B-52

HB 395 . . . . . . . B-55

NEW YORK

$\mathrm{AB} 8620$. . . . . . . B $\mathrm{B}-57$

NORTH CAROLINA

SB 375 . . . . . . B-73

NORTH DAKOTA

SB 2439 . . . . . . B-76

OHIO

Amended Substitute IiB 584 • B B-77

(eight pages out of 42)

OREGON

HB 2036 . . . . . . . B-85

$\mathrm{HB} 2202$. . . . . . B

SOUTH DAKOTA

SB 283 . . . . . . . B-93

TEXAS

HB 546 . . . . . . . . B-94

(two pages out of 49 )

VIRGINIA

HB 1809 . . . . . . . B 96 


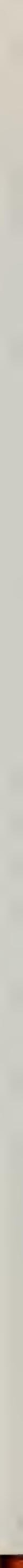


Ch. 93

32nd LEGISLATURE

\section{INCOME TAX-SOLAR ENEIRGY-EXPENDITURES, AMORTIZATION}

\section{CHAPTER 93}

\section{SENATE BILL 1011}

-

An Act rolating to taxation of income; providing for tax deduction for installation of solar enorgy devlcos, and amending section 43-123.37, Art- zona Rovised Statuter.

Be It enacted by the Legislature of the State of Arizona:

Section 1. Scction 43-123.37, Arizona Revised Statuteg, is amended to read:

143-123.37. Election to amortizo expenditures incurred in the acquisition of any solar energy device deslgned to produce heat or oleoiricity

(a) Gonoral Ruio. Any taxpayer may elect to amortize the adjusted basis of any solar energy deviee. whether for residential. commercial, industrial or governmental installations or experimental or demonstration jumjects, desigued to produce heat or eiectricity based upon a feriod of sixty months. In computing net income, such umortization shall te allowed as a deduction ratably over the period allowed under this subsection beginaing with the month in which such device is completed or acquired and is plnced in service by the taxpayer. This election shall be indicated by the taxpayer in au appropriate statement in the taxparer's income tax return for the taxabie year of the acquisition or completion and placement in service of such devicz. An election to discontinue amortization with respect to the remainder of the amortization period is permitced and sluall he indicated by an appropriate statement in the taxpayer's income tax retura for the taxable year of iiscon. tinnance.

(b) Deduction in lleu of deproclation. The deduction prorided under subsection (a) shall be in lieu of any allowance for the exhaustion, wear and tear of property used in a trade or busimess, or of property hcld for the production of income, including a reasonable allowance for obsolescence as provided under \& 43-123.14.

(c) Determining the adjusted basls. In deternining the adjusted basis for the purposes of subsection (a), such device, shall inciude ouly an anount that Is properly attributable to the construction, reconstruction, remodeling, installation or acquisition of such device.

(d) Dofinition. In this section and 12-123.01, "Solar energy device" means a system or a series of mechanisms designed primarily to provide heating, to provide cooling. to produce electrical power, to produce inechanical power, or any combination thereor, by means of collecting and transferring solar-generated energy into such uses und which also may have the capability of storing such euengy for future utilization.

Approved by the Governor, May 22, 1975.

Filed In the Office of the Secretary of State, Msy 23, 1975. 


\title{
SOLAR ENERGY-RESEARCH; DEVELOPMENT
}

\author{
CHAPTER 20
}

\section{SENATE BILL 1018}

An Act rolating to state government; ostabllshing a solar energy research commission; providing for an executive director of the commission; deserlbing powers and dutles; repeallng titio 4l, ohaptor 3, article 6 , Arizona Rovlsod Statutes: amonuling tille 41, chapter 3, Arizona Revised Statutes, by adding a new article 6; making an appropriation, and providing for explration dato.

Be it enacted by the Levialature of the State of Arizoma:

Section I. Ropeal

Title 41, chapter 3 , article 6 , Arizona Revlsed Statutes, is repealed.

Bec 2 Title 41, chapter 3, Arlzona Revised Statutes, Is amended by adding a new artlcle 6 , to read:

\section{ARTICLE 6. SOLAR ENERGY RESEARCH COMIIISSION}

41-57I. Dofinitions

In this artlele, unless the context otherwise requircs:

1. "Adranced alternate ellergy srstem" means an euergy generation system utillzing loupollutiug. renewable enerky sources including, but not limited to, solar enerky sources.

2. "Commlssion" means the solar eneroy researeh commlsslon.

3. "Executire director" mieans the exeentlve director of the solar energy research commission.

4. "Institute" means the natlonal solnr energy research institute.

5. "Intermedlate solar energy sources" include, but are not limited to, tuels or energy llerived fmm wind, sea thermal gradients, procluets of photossnthetlc proceswes, organic wastes and the coubination of sitch fuels or enerky with waste or process heat.

6. "Solar energy" means ellergy whieh has recently orlginated In the sun, Including, hut not llmiterl to, direct and indirect solar radiution and Internedliate solar encrus sollrees.

51-572. Solar onergy research commission; members; vacanclos; appolnt. - ment; compensation; meetings

A. There is established a solar energy rescurch commission conslsting of the following nembers:

1. The chalrman of the Arizonu power authority.

2 A memher of the fuculty at Arlzona State Unlversity, who shall be appolnted hy the covernor.

3. A meinher of the fuculty at the university of Arizoua, who shall be appolnted hy the enovernor.

4. A member of the enculty at northern Arlzona university, who shall be appoliteil hy the goveruur.

dalotlons by attheouts 


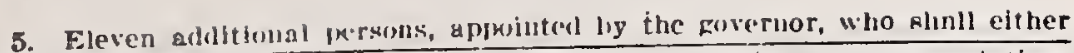

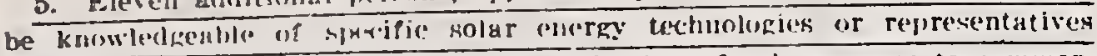
of prisate industry involval in the mpllication of solur eneray to crmmercial. Industrial ur residential use.

6. The Jresillent of the A rizsun kenate and the spmaker of the house of representatives or thoir reprowentatives, shall le ex officio memlers.

B. Appointments made by the governor shall be for a term which expires on tbe termination date of this articele. Apmunment w fill a vacanrs shall be made pursuant to the provisions of 8 ist-211.

c. Members of the commission serving by virtue of their office shall serve without commensation. Apminted menims shall receive compnsatlon as determined porsuant to $34-611$ for each day of attendance upon meetlngs.

D. The chairman of the commission shall be selected by the rovernor trom among the memivers.

E. The commission shall meet upon enll of the chatrman.

5 41-573. Executlve director; appolntment; employees; compensation

A. There shall be an expeutive dircetor of the commission who shall be appointed by the governor pursuant in $\&$ is-211.

B. The executive direetor shall be responsible for the administratire functions of the commission and shall implement polieies as directed bs the commission.

C. The executlve direetor may employ such clerical and teehnteal assistants as are necessary to carry out the pricitas of the commission.

- D. Compensation for the executive director and other cmplovees of the commision shall be estalulished mursoant to $85-611$.

51-574. Powers and dutles

The executive director, in consultation with the solar energy research commission, shall:

1. Initiate and develop a systematic plan deslgned to meet all of the requirements of $\mathrm{A}$ national solnr eneray reseilreh iustitute pursuant to the United States Solar Energy Research and Deinonstration Act of 1974.1

2. Cooperate, when in the best interests of the state, with all federal gorerument agencies resmonsible for implenumtation of the Initer stares Solar Fuerky lesegrch and lennoustration Aet of 1974 to condinate and encourage the support of ull solar and advaneed alternate energy systems researeh, development und demonstration in order to encourage the final decision to locate such institute within this state.

3. Encuurage efforts by reseancli institutions, local gorernment institutions and home builders in nlifaining terhnieal und financial support trom the federal goverument for their activities in solar aud advanced alternate energy srstems.

4. Collect, assemble and nualyze information and data relating to solar energy tecluoloks, Including the following:

(a) Federal lefislation and Pelleral agency sponsored progtams and projects. 
(b) Legisiation ellacted and programs or prijects undertaken by this state and otlier atates.

(c) Projects milertuken or to ins undertaken hy prlvate flrms and nonprofit Institutions, foumlations and Iulkratories.

(d) Innovations and nses developed by other countries.

5. Identify und descrile the solur enerky technolngies that are feaslble and practical in terms of short torn applicatlon of retrofit new construction and conservatlon projects within flve sears.

6. Identify and descrlle lulg range programs that are feaslble and re quire signlficant tecluological development. I'rograms having similar technological gradients sliall he foriuulated to elicomnass the period of tlme from the present through the year $20: 21)$.

7. Recommend an organizational structure for the Institute that wllI provide the functional properties necessary to execute the development or research requireuents, analysis of ferleral contruct plans, identification or edicational curricula refuirements, legislation emphasis and data collection needs of the institute.

8. Encourage the conperation and direct Involrement of academic, business, professional and Industrial sectors that are determined to have special expertise or knowledge of solar enerzy technology.

9. Prepare interin reports and suhuit copies theroof to the lecislature and the governor during June. 1975. June, 1976 and June, 1975 and a final report during December, 19ix. Such repurts shall include specific recommendations necessary for the supmort of the institute and any of its satellites.

10. If Arizona is selected as a slte for the institute. finly cooperate for the prorision of a suitable permanent site and trausitional needs during the time the institute facilities are under construction.

\section{12 U.S.C.A. 5551 et seq.}

Sec. 3. Approprlatlon; lapsing

A. The sum of seventy-five thousand doliars is appropriated to the solar energy research commlssion to carry out the purposes of this act.

B. The appropriation made bs sulisectlon $A$ of this section is exempt from the jrovisions of $35-190$, Arizona IRevlser Statutes, relating to lapsIng of appropriations, except that all monies remaining unencumbered or unexpended on Dccemher 31,1978 sliall revert to the general fund.

Sec. 4. Explration of act

The provislons of thls act shall explre and the commission establlshed by it shall terminate on December 31,1978 .

Sec. 5. Emergency

To preserve the publlc peace, heaith and safety it is necessary that this act become immediately oneratire. It is therefore declared to be an emergency measure, to take effect as prorided by law.

Approved by the Governor. May 8. 1975.

Flied in the Offlce of the Secretary of State, May 9.1975. 


\section{TAXATION-VALUATION; SOLAR ENERGY \\ CHAPTER 165}

SENATE BILL 1231

An Act rolating to taxation and taxation of Iscoma; prescribling powers and dutles of the department of revenue; prescribing tax benefits for In. stallation of solar energy devlce desloned to produce heat or electrlcity; amending tltlo 42, chapter 1, articlo 2, Arlzona Revised Statutes, by addino eoction 42-123.01, and amending title 43, chapter 1, artlclo 1, Arlzona Revised Statutes, by adding. section 43-123.37.

Be it enacted by the Legislature of the State of Arizona:

Bection 1. Title 42, chapter 1, artlcle 2 is amended by adding section 12-123.01, Arizona Revised Statutes, to read:

3 42-123.01. Alternate powers and dutles of department

A. Notrithstanding the provislons of $42-123$ and until December 31 , 1084, the department shall:

1. Exercise general supervision over county assessors in the administration of the state property tax laws of the state for the purpose of insuring that all property is uniformly valued for state property tax purposes.

2. Prescribe rules and regulations relating to the enforcement of the powers and duties of the department uncer the provisions of this title.

3. Requlre the use by the county assessors of prescriled forms for the latlng and valuing of propercy for tax purposes, the reporting of chanmes in valuationg and for such other purposes as may be required by the department under the provisions of this title.

4. Require county assessors to maintain unirorm maps and records.

5. Adopt standaru appraisal methous and techniques for use by the department and county assessors in determiniug the valuation of property, and prepare and maintain manuals and other netessary fuidelines reflecting such methods and techniques in order to perpetuate a current inventory of all property subject to taxation and the valuation thereor. In the standard appraisal methods aud tecbniques adopted current usnze shall be included In the fornula for reaching a determination of full cash ralue and when tho methods and techniques udopted prescribe the use of mariet durs as an Indlcation of market value, the price paid for fucure anticipated property value lncrenients aud any solar euergy derice, us defiued in subdivision (d) of 8 43-123.37, shall be excluded.

6. Requlre the county assessors to meet with the director at the state capltol, or at a place desiguated by hiru, at least twice a sear for the purpose of consldering matters reluthng to property taxation. The traveling trivenses of assessors in attending such meetings shall be paid by the respective counUlea.

7. Inrestigate property valuatlons and any matters relatlng to property taxes and requlre the production of any private or public recurd relating

698

Changes or additions in texi are Indlcated by underllne 


\section{SECOND REGULAR SESSION-1974 Ch. 165}

to such valuations or property taxes. The director or hls agent may enter upon and examine any and all pronkerty within the state for the purpose of determlnlng lis full cash ralue and require ang officer whose duties relute to the assessment or collectlon of tnxes to report to him at such time and in such manner as he prescribes. In the event the owner or possessor of property refuses entrance to the director or his apents, the raluation of such property may be estimated by the director.

8. Requlre the use by county assessors of such a data processing system as the department may prescribe, provided that any county assessor having a data processing system compatible $w$ ith the ssstem prescrlbed hy the department may contlnue to use his own system as long as it is coordinated with the system prescribed by the department.

8. Contract with the counties to furnish electronle data processing equipment in instances where the counties do not hare the equipment necessary to meet the requireroents of the department.

10. Furnlsh assistance to the county assessors in order to implement placement on the rolls of the raluations determined under article 2.1 of this ehapter and to assure a uniform valuation of all property throughout the state for property tas purposes, including but not lirolted to the prorlding of servlces of department personnel to the counties, provided that suhsequent to June 30, 1968 the cost of providing the services of department personnel to the countles shall be charged to the county serred.

11. Furnish the state board with such information as it may request.

12. At such time as the state acquires from the national aeronautics and space administration orthophoto buse mups for use by all departments of Arizona state gorernment and others in need of such maps. charge for duplication and sale of these maps and deposit such rerenues in the state general fund.

B. The department may:

1. Examine Into all alleged vlolations of the prorislons of this title relating to the raluation of property and the assessment and collection of taxes and request the attorney general or the county attornes in their respective counties to commence and prosecute actions and proceedings or to represent countles to eommence and prosecute actions and pruceedings or to represent the department in litication to enforee the laws relating to taration and orders, or the rules and regulations of the department. When in the epinion of the director and in the opinion of the attoruer feneral or the county attorney in rhich the publle official serres a public official, who performs ralulng, taxlng or equalizing functions, is guilts of official misconduct or neglect of duts, the director shall take whatever steps a re necessary to insure that complaints are filed and prosecutions commenced a aainst such offlclals for thelr removal from office. A complaint hy the director charging offieial misconduct or nezject of dity of a public officer shail be delirered to the county attorney or to the attorney peneral who shall file the orlginal Dith the superior cuturt in the county in which the punlic official serves and cause a copy thereof to be served upon such public official. Proceedings np- 
on such complalats shall be in accorrlance with the provisions of subsections $B$ and $C$ of $33-342$, and $8838-343$ and $33-345$.

2. Study the tax systems of other states.

3. Employ technical experts and assistants and make contracts for servlees as may be required to carry out its duties.

4. Appoint advisory committees representative of various classes of property.

5. Request the attorney general to initlate a mandamus action if any assessor falls to follow any regulation, rule, order or direction of the director or the department or If the director detcrmines that an assessor, or a cuunty board of equalization has practiced discrimination in the valuation of property. For the purposes of this section, county bonards of equalization and the county assessors are state off!cers within the meaning of article 6 , section 5 of the constitution of Arizona.

6. Contest any proposed valuation or classification or ang proposed change In valuations or classifications before any county board of equalization or before the state board of tax appeals. If ang decision of ang county board of equallzation or of the state hoard of tax appeals is, in the opinion of the director, erroneons, the director may appeal such decision to the superior court in the manner provided in $\$+2-151$, on or before the finul date a tarpajer may flie an appeal from the valuation or classificatlon of his property.

7. Seil contact prints of any national aeronauties and space administration orthophoto base maps acquired by the department and deposit such revennes in the state general fund.

Sec 2. Title 43, chapter 1, article 1. Arlzona Revised Statutes, Is amended by adding section $43-123.37$ to read:

13-123.37. Election to amortize oxpenditures incurred in the acquisition of any solar energy devlce designed to produce heat or olec triclty

(a) General Rule. Ang taxpayer may elect to amortize the adjusted basis of any solar encroy device designed to produce heat or electricity based upon a period of sixty months. In computing net iucume, such amortization shall bo allowed as a deduction ratably over the period allowed under tinis subsectlon beginning with the month in which such device is completed or acuuired and is placed in service by the taxpiyer. This election shall be isdicated by the taxpayer In an appropriate statement in the taxpayer's lncome tax return for the taxahle jear of the acquisition or completion and placement in ser:Ice of such derice. An election to discontinue amortization with respect to the remainder of the amortizatlon period is permitted and siall be indlcated by an appropriate statement in the taxpayer's Income tar return for the taxable year of discontinuance.

(b) Deduction in lleu of depreclation. The deduction provided under subsection (a) shall be in lleu of any allowallcc for the exhaustion, wear aud tear of property used in a trade or huslutss, or of property held for the pro- 


\section{SECOND REGULAR SESSION-1974 Ch. 166}

duction of income, lncluding a reasonable allowance for obsolescence as prorided under 43-123.14.

(c) Determining the adjusted basls. In determining the adjusted basis for the purposes of subsection (a), such device, shall include only an amount that is properly attributable to the constructlon, reconstruction, remodeling. installation or acqulsition of such device.

(d) Dofinition. In this section and 42-123.01, "Solar energy" device" means a system. or a serles of mechanisms designed primarily to provide heating, to provide cooling, to produce electrical power, to produce mechanlcal power, or any comblnation thereof, by means of collecting and transferring solar-generated energy into such uses and which also may have the capability of storing such energy for future utlllzation.

Soc. 3. Effectlve date

The provisions of this act shall become effective retroactive to the taxabie year beginning from and after December 31, 1973.

Sec. 4. Explration date

The provisions of this act shail explre with the tarabie year beginning from and after December 31, 1984.

Approved by the Governor, May 15, 1974.

Filed in the Office of the Secretary of State, May 15, 1974. 


\section{CHAPTER 276}

An act to amend Section 21100 of, and to add Division 15 (commencing with Section 250:20) to, the Public Resources Code, and to repeal Chapter 11 (commencing with Section 19370) of Part 3 of Division 13 of the Health and Safety Codc, relating to energy resources.

[Approved by Governor Miny 21, 1974. Filed with Secretary of State May 21, 1974]

\section{LEGISLATIVE COUNSEL'S DIGEST}

AB 1575, Warren. Energy resources.

Requires specifically that an environmental impact report prepared pursuant to the Environmental Quality Act of 1970 include a statement of measures to reduee wasteful, ineffieient, and unneeessary consumption of energy.

Enacts the Warren-Alquist State Energy Resources Conservation and Development Act.

Declares legislative findings relating to energy resourees.

Establishes the State Energy Resources Conservation and Development Commission and prescribes its membership, powers, and duties.

Provides for forecasting and assessment of energy demands and supplies, and for conservation of energy resources by designated methods.

Requires, with exceptions, that power sites and facilities, as defined, be certified by the commission, as preseribed.

Requires the commission to develop and eoordinate a program of research and development in energy supply, consumption and eonservation and the teehnology of siting facilities.

Provides for developinent of contingency plans to deal with possible shortages of electrieal energy or fuel supplies.

Imposes various fces and requires the money to be deposited in the State Energy Resources Conservation and Developinent Speeial Aecount, which is established in the General Fund. Requires that money from such account be expended for purposes of earrying out the provisions of this aet, when appropriated by the Legisiature in the Budgct Act.

Deletes designated provisions providing for the establishment of energy insulation regulations for residential buildings, with deletion to be operative on the date one year after the date the commission adopts regulations pcrtaining to suel subject inatter.

Provides that there shall be no reinbursement pursuant to Seetion 2231 of the Revenue and T:axation Code nor shall there be any appropriation made by this act, for spccified reasons. 


\section{Chapter 5. Energy Resources Conservation}

25400. The commission shall conduct an ongoing assessment of the opportunities and constraints presented by all forms of energy. The coinmission sha!l encourage the balanced use of all sources of energy to mect the state's needs and shall seek to avoid possible undesirable consequences of reliance on a single source of encrgy.

25401. The commission shall continuously carry out studies, research projects, data collection, and other activities required to assess the nature, extent, and distribution of energy resources to meet the needs of the state, including but not limited to, fossil fucls and solar, nuclear, and geothermal energy resources. It shall also carry out studies, technical assessinents, research projects, and data collection directed to reducing wasteful, inefficient, unnecessary, or uneconomic uses of energy, including, but not limited to, all of the following:

(a) Pricing of electricity and other forms of energy.

(b) Improved building design and insulation.

(c) Restriction of promotional activities designed to increase the use of electrical energy by consumers.

(d) Improved appliance efficiency.

(e) Advances in power generation and transmission technology.

(f) Comparisons in the efficiencies of alternative methods of energy utilization.

The commission shall survey pursuant to this section all forms of energy on which to base its recommendations to the Governor and Legislature for elimination of waste or increases in efficiency for sources or uses of energy. The commission shall transmit to the Governor and the Legislature, as part of the biennial report spccitied in Section 25309, recommendations for state policy and actions for the orderly development of all potential sources of energy to meet the state's needs, including, but not limited to, fossil fuels and solar, nuclear, and geothermal energy resources, and to reduce wasteful and inefficient uses of energy.

25402. Within 18 months after the effective date of this division, the commission shall, after one or more public hearings, do all of the following, in order to reduce the wasteful, uneconomic, inefficient, or unnecessary consum: tion of encrgy:

(a) Prescribe, by regulation, lighting, insulation, climate control systems, and other building design and construction standards which increase the efficient use of energy. Such standards shall be economically feasible in that the resultant savings in energy procurement costs shall be creater than the cost of the energy conserving requirements amortized over the econoinic life of the building. In prescribing standards for insulation, the commission shall take into consicleration the standards developed pursuant to Chapter 11 (commencing with Section 19870) of Part 3, Division 13 of the Health and Safety Code, which standards shall only be 
operative until the datc one year after the date that the conunission adopts regulations for energy insulation for rcsidential buildings pursuant to this subdivision. One year after the commission adopts the regulations pursuant to this subdivision, no city, county, city and county, or state agency shall issue any building pernit unless the standards prescribed by the commission pursuant to this section are satisfied. Whenever the provisions of this subdivision and the provisions of Chaptcr 11.5 (commencing with Section 19978) of Part 3 of Division 13 of the Health and Safety Codc, as to adoption and enforcement of standards for "nonresidential buildings" as defined by Section 19878.1 of the Health and Safcty Code, are in conflict, the commission shall be governed by the provisions of such chapter of the Health and Safety Codc to the extent of such conflict.

(b) Recommend per unit energy requirement allotments based on square footage for various classes of buildings which would rcduce the growth rate of electrical energy consumption and which are technically feasible and will provide adcquate sareguards for public health, safety, and welfare. No city, county, city and county, or state agency shall issue any permit for the construction of any building unless the applicant certifies that consideration has bcen given to such energy requirement allotments, which certification shall include a statement specifying the extent to which conformance with the relcvant recommended allotment will be achieved.

(c) By regulation, prescribe standards for minimum levels of operating efficiency, based on a reasonable use pattern, for all appliances whose use, as determined by the commission, requires a significant amount of energy on a statewide basis. Such minimum levels of operating efficiency shall be based on feasible and attainable efficiencies or fcasible improved efficiencies which will reduce the electrical energy consumption growth rate. One year after the date of the adoption of such standards, no new appliance may be sold or offered for sale in the state which is not certified by the manufacturer thereof to be in compliance with such standards. Such standards shall be draivn so that they do not rcsult in any added total costs to the consumer over the designcd life of the appliances concerned.

(d) Recommcnd minimum standards of efficiency for the operation of any new facility at a particular site which are technically and economically feasible. No site and rclated facility shall be certified pursuant to Chapter 6 (commencing with Section 25500) of this division, unless the applicant certifies that standards recommended by the commission have been considcred, which certification shall include a statcment specifying the extcnt to which conformance with the recommended standiurds will be achieved.

Whenever the provisions of this section and the provisions of Chapter 11.5 (commencing with Section 19:378) of Part 3 of Division 13 of the Ifcalth and Safety Code are in conllict, the cominicsion shall be governed by the provisions of such chapter of the Health and Safety Code to the extent of such conflict. 
a special fund in its budget for the reimbursement of costs incurred by local agencies.

25539. In reviewing notices and applications for ccrtification of modifications of existing facilities, the commission shall adopt rules and regulations as necessary to insure that relevant duties pursuant to this division are carried out.

25540. If a person proposes to construct a geothermal powerplant and related facility or facilities on a site, the commission shall not require three alternative sites and related facilities to be proposed in the notice. In considering the proposed construction of a geothermal powerplant and related facilities on a site, the commission shall issue its findings on the notice as specified in Section 25516 within nine months from the date of filing of such notice, and shall issue its final and decision on the application as specified in Section 25523 within nine months from the date of filing of the application for certification, or at such later time as is mutually agreed by the commission and the applicant or person submitting the notice.

25541. The commission may exempt from the provisions of this chapter thermal powerplants with a generating capacity of up to 100 megawatts and modifications to existing generating facilities which do not add capacity in excess of 100 megawatts, if the commission finds both of the following:

(a) No substantial adverse impact on the environment or energy resources will result from the construction or operation of the proposed facility or from the modifications.

(b) . Generating capacity will not be added which is substantially in excess of the forecast of electrical energy demands adopted pursuant to subdivision (b) of Section 25309.

25542. In the case of any site and related facility or facilities for which the provisions of this division do not apply, the exclusive power given to the commission pursuant to Section 25500 to certify sites and related facilities shall not be in effect.

\section{Chapter 7. Research and Developaent}

25600. The commission shall develop and coordinate a program of research and development in energy supply, consumption, and conservation and the :clinology of siting facilities and shall give priority to those forms of research and development which are of particular importance to the state, including, but not limited to, all of the following:

(a) Methods of energy conservation specified in Chapter 5 (commencing with Section 25400).

(b) Increased energy use elficiencies of existing thermal electric and hydroelectric powerplants and increascd energy efficiencies in designs of therinal electric and hydroelectric powerplants.

(c) Exploration and accelerated developinent of alternative sources of energy, including geothermal and solar energy resources. 


\title{
SCHOOIS II - STATE UVIVERSITIES, COLLEGES, AND ACADLiIES
}

\author{
SCHOOL OF MINES - ENER.GY RESEARCH INSTITUTE
}

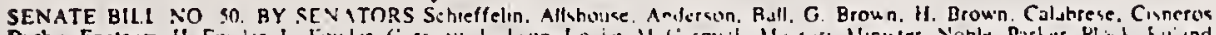

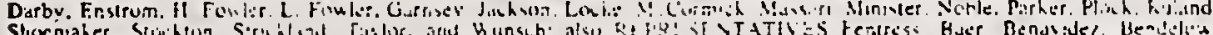

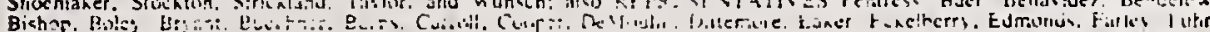

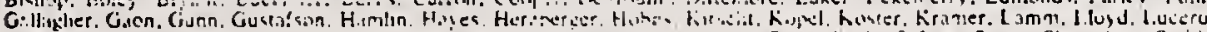

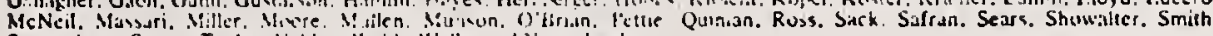
Sonnenberg. Spano. Tastor. V'ulder. Wetb. W'ills. and Yunglund
\end{abstract}

\section{A N A C T}

CRF.ATING THE E.VERGY RF.SE.ARCH INSTITUTE AT THE COLORADO SCHOOL OF MINES. AND M.IKING AN APPKOPRTATION THIEKEFOR.

\section{Be it enacted by the General Assembly of the State of Colcrado:}

Section 1. Article 9 of chapter 124. Colnrado Revised Statutes 1963. as amended, is amended BY THE ADDITION OF THE FOLLOWING NEW SECTIONS to read:

124-9-19. Colorado energy research instiute - creation. (1) There is hereby created at the Colorado schoul of mines the Colorado energy rescarch institute, reforred 10 in this section as the "institute". It is the intent of this section that the institute serve as a mechanism for the development and coordination of energy and energy-relited minerals research programs including prograns at single state or private educitional or research institutions and multidisciplinary. interuniversity. government-university. and industry-university energy and energy-related minerals research programs and piojects. It is the fut ther intell of this section that the institute provide the mechanism for enhaneing the development and promorion of energy and eneroy-lelated minerals educution programs in the state.

(2) The principal administrative officer of the institute shall be the president of the Colorado schon! of mines. and hudgetary and fiscal procedures and activities of the institute shall he under the supervision of the school of mines. To meet fully the intent of this ecetion. the principal administritive officer, together with an advisory council on energy research formed pursuant to section 12-4.y.2(). shall be responsible for developing appropriate administrative structure and process. These should be devigned to insure that the institute accomplishes its purpores and tecomes a stats instrumentility facilitating development athd coordination amving all programs and projects concerned with encrgy and energ!-related minerals research. The advisory 
council shall review proposils and expendiaures. and when possithe shall

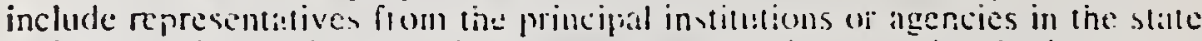

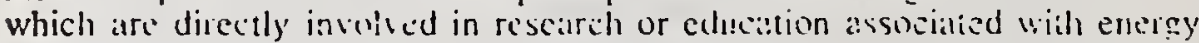

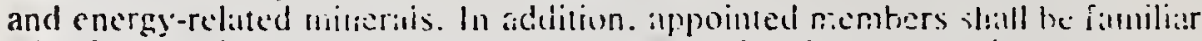

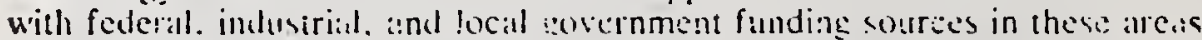
and should coordinate the dissemination of information liciessary to latilitate the preparation of higlt quility proposils for research from all concerned institutiens and agencies in the state.

(3) It is the duty of the institute to:

(a) Maintain liaison with the state to identify the important regional energy and conergy-lelaticd minerals problems, including their relationship to the use of the waters of thic state;

(b) Inventory Colorado tinhter education faculty menters and state oroanization emiployees with energy and encry!y-related minsals related rescarch experience and update this tuivulation ammuaily;

(c) Conrdinate and promote the development of energy and energy-related minerals research prograins and projects in single or multiple disciplines at state and private educational and research institutions:

(d) Coordinate the development of interuniversity. industry-university, and governmcnt-university energy and energy-related minerals research projects:

(e) Coordinate the evaluation of the economic, social, medical. educational, and emironmentil impact of various energy and energy-related nuirerals policies:

(f) Develop and promote energy and encrgy-related mincrals education programs in the state.

(4) Any state agency maliing any froposal for funding research concerning energy or energy-felated minerals shall be required in submit such proposal to the institute for conment. The ilistitute shali make such comment as is deenued apprepriate to ihe investigator and tha agency to which the proposal was subnitted within thitty days of its receipt of the proposal.

(5) The institute is herchy authorized to receive federal or private funds for energy or encrgy-latcd mincra:ls research projects for furtliering the purposes of the institule. Funde received shall be applopristed by the general

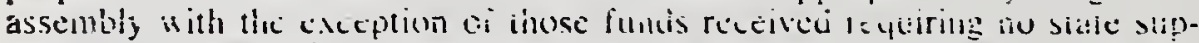
port directly or indiretty. Which funds will be reported to the joint buciget commitice upon recipt.

124-9-20. Advisory council on ellergy atal energy-pelated minerals researcil. (1) There is hereny created the adsisory cotincil on ene?y and encrgy-related mincrals reasuch consisting of clevell nemters. Tike prinury function of the advisory commission is to estahbisti gelieral policy guide lines for implementin! the intent of this section and to regularly evibluate the development of the Colorinio energy resear terms of acrall objectives. The membership of the advisory combit silet include four es officio niemhers as folfows: The excentive direstor of the

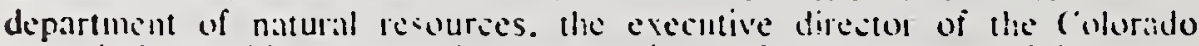
commission on higher ecilliation. the pesident of th: university of culurato, 


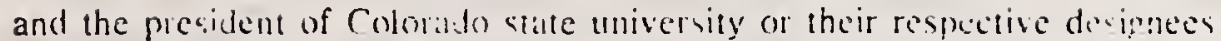
and seven members apforited by the governor which shall inctule one

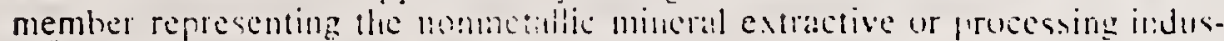
try, one member replesemins tive metallic mineral extractive or parsessing

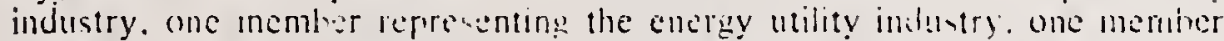
representiug envilommentil interests. one member represeniing the oil and gas industry or the wit stake industry. and two members representing tocil governnicnt. One of the menters of the atvisory council shall be designated by the governor as claimana.

(2) The term of each member of the advisory courcil apfointed by the governer is three years. Of those menubers first appointed. Iwo shatl he appointed for a term of one year. two for a term of two t:ars. and three

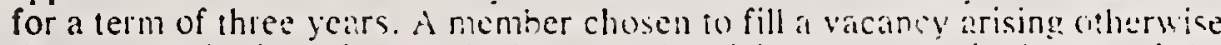
than by expiration of term shall tie appoinied for the us: ypired term of the member whim he is to succed. A member of the adviso: council is ciiale for reappoinanest for une llaed-ycá ierm.

(3) The advisory council shall advise and consult with the Colorado energy resciarch institute and matic recommendations to assist in carrying out the purpuses of this article.

(4) Hembers of the advisory council shall serve without compensation but are cntilled to reimbursement of actual and necessary expenses incurred in the performatnce of their duties.

Section 2. Appropriation. There is hereby appropriated to the Colorado sehool of rines for the Colurado energy rescarch institute. for the fiscal year commencing July 1. 1974. the sum of iwo million eight hunkred sisty theusand dollars $(\$ 2.860 .000)$. of which nine hundred ton thousand dolluti (\$910.000) shall be out of any moneys in the state treasury not otherwise appropriated. ard one ralltiun nine hindred fifty theusand doltars (\$1, y:0.0.00) shall be from federal funds for the following purposes:

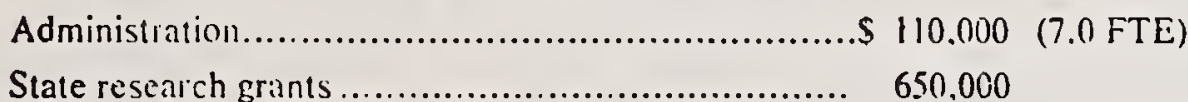

Federal funds .......................................... 1.950 .000

One hundred academie one-year scholar-

ships to be distributed where possible

on a statewide geographic basis ........................ $\quad 66.000$

Eighteen scholarships for demonstralted need

Ten retraining fellow ships

Where all cualifications for the above scholurships and fellow clips are eciual among applicanis, preiemence will be given to Culorabo resileme who are veterans who served in the linited States atrmed fores on active dury fur any period hetween Alusust 5 . 1964. throusid dusust 5 . 1973. and who vere diseharged of released firom active duty under honorable conditions.

Section 3. Sidet: clause. The eneral assembly lereby finds detcrmines. and declares that this ate is necestary for the immediate preservation of the public peace, healtli. and siffety.

Approved: May. 8. 1974 


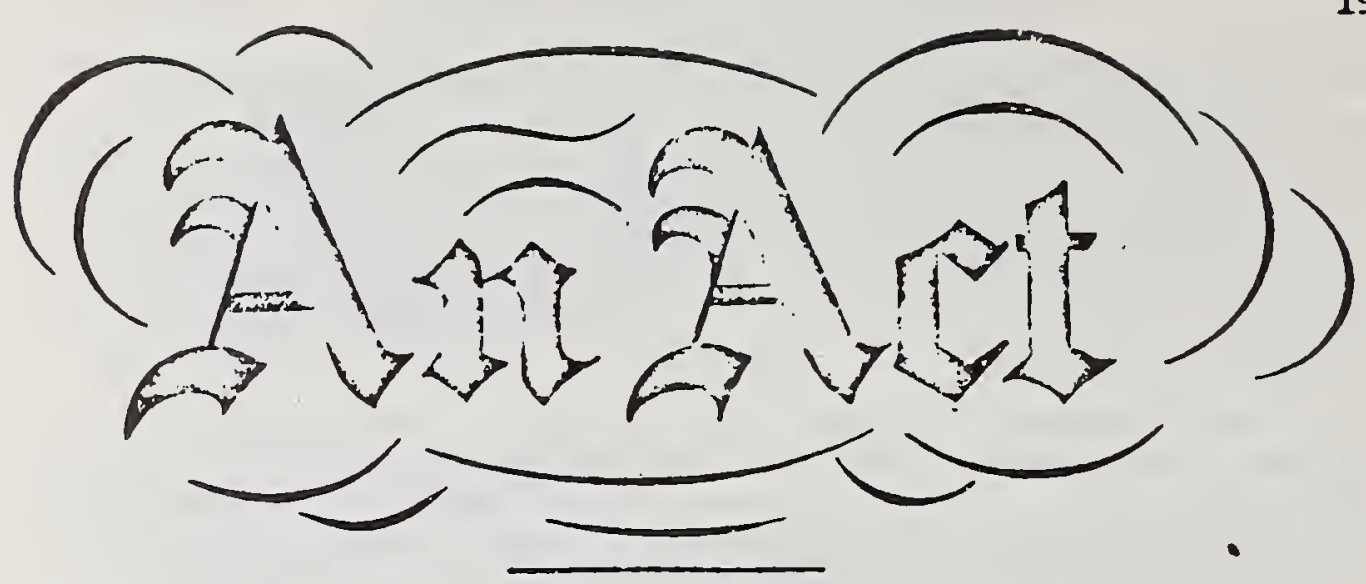

SENATE BILL NO. 75. BY SENATORS Schieffelin, Anderson, Bishop, Cooper, Deberard, H. Fowler, llatcher, Ilughes, Jolunson, AcCormick, Smedley, liunsch, Allshouse, Cisneros, Darby, L. Fariler, Gallagher, Holne, Kadlecek, Kogovsek, Mac'lanus, ifinister, Sandoval, Stockton, and Strickland; also REPRESENTATIVES Frank, Bendelow, Brown, Burrows, De'foulin, Dick, Durham, Elliott, Flanery, Gaon, Ililsmeier, llobbs, llogan, Nuinlan, Sprague, Taylor, Waldow, and Witherspoon.

CONCERNING THIE VALUATION FOR ASSESSAENT OF SOLAR HEATING OR COOLING DEVICES.

Be it enacted by the General Assembly of the State of Colorado:

SECTION 1. 39-1-104, Colorado Revised Statutes 1973, is amended BY TIIE AUDITION OF A NDW SUBSECTION to read:

39-1-104. Valuation for assessment. (6) The valuation for assessment of all solar heating or cooling devices attached to or a part of any building irmprovement shall be at an amount equal to five percent of the actual value the reof as determined by the assessor in accordance with the regulations of the property tax administrator. For the purposes of this subsection (6), solar heating, solar hot water, or solar cooling devices shall include all controls, tanks, pums, heat exchancers, and other narhivere necessary to effect the installation of a solar heating or cooling system. Solar hearing or cooling devices shall not include walls or roofs unless those portions of the structiure shall be a part of those devices specifically designed into the system to provide additional heating or cooling that would not ordinarily be contained in a structure not designed or modifiec to provide solar heating or cooling.

SECTION 2. 39-5-105, Colorado Revised Statutes 1973, is

Capital Tetters indicate new material added to existins, statutes; dashes through words indicate deletions from existing statutes and such naterial not part of act. 
amended to read:

39-5-105. Improvements valued semarately - when. Improvements shall be alpiraised and valued separitc ly from land, except improvements on land which is used solely and exclusively for agricultural purposes, in which case the land, water ringts, and improvements shall be anpraised and valued as a unit. IN APPRAISIVVG AND VANUING IRPROTEM:TS ANY DEVICE W:IICI IS ATTARITD TO A BUILDIVG OR STRLCTUPS: OR HIICII IS N INTECRUL PART OF SUGI STRUCTURE AND IS DESICVED TO PROVIDE SOLAR IEATII:G OR COOLING SIALL BE APPR.IISEI) ADD VALUTD SEPARITELY FROI SUOI BUILDINIF OR STRUCTURE. SUCI SEPARATE APPRAIS.L AID VALUATID:I SLLL BE ILUE UPON NPPLIC.TIION OF TIE OU.TER OF TIE II.PROVRIENT TO TIE ASSESSOR. THE PROPERTY TAX AIMIINISTTHTOR SLALL PRCI ULCATT RERULATIDNS FOR THE UNIFORY ADIINISTRATION OF TIIS SECTION AND SILLL PROVIDE AN APPROPRIATE APPLICATION FORY.

SECTION 3. Effective date - anplicability. This act shail take effect July 1, 1975, and shall apply to tax years beginning January 1, 1976.

SECTION 4. Safety clause. The general assembly hereby finds, determines, and declares that this act is necessary for the inmediatc preservation of the public peace, health, and safety.

Fred E. Anderson

PRESIDENT OF

IFIE SENATE
Ruben K. Valcez

SPENKER OF MIE HOUSE

OF REPRESENTATIVES
Comfort hi. Shaw

SECRETARY OF

THE SENATE
Evelyn T. Davioson

CHIEF CLERK OF MIE IIOUSE

OF REPRESETTATIVES

APPROVED

Richard D. Lamun

COVERNOR OF MIE STATE OF COLCRADO 


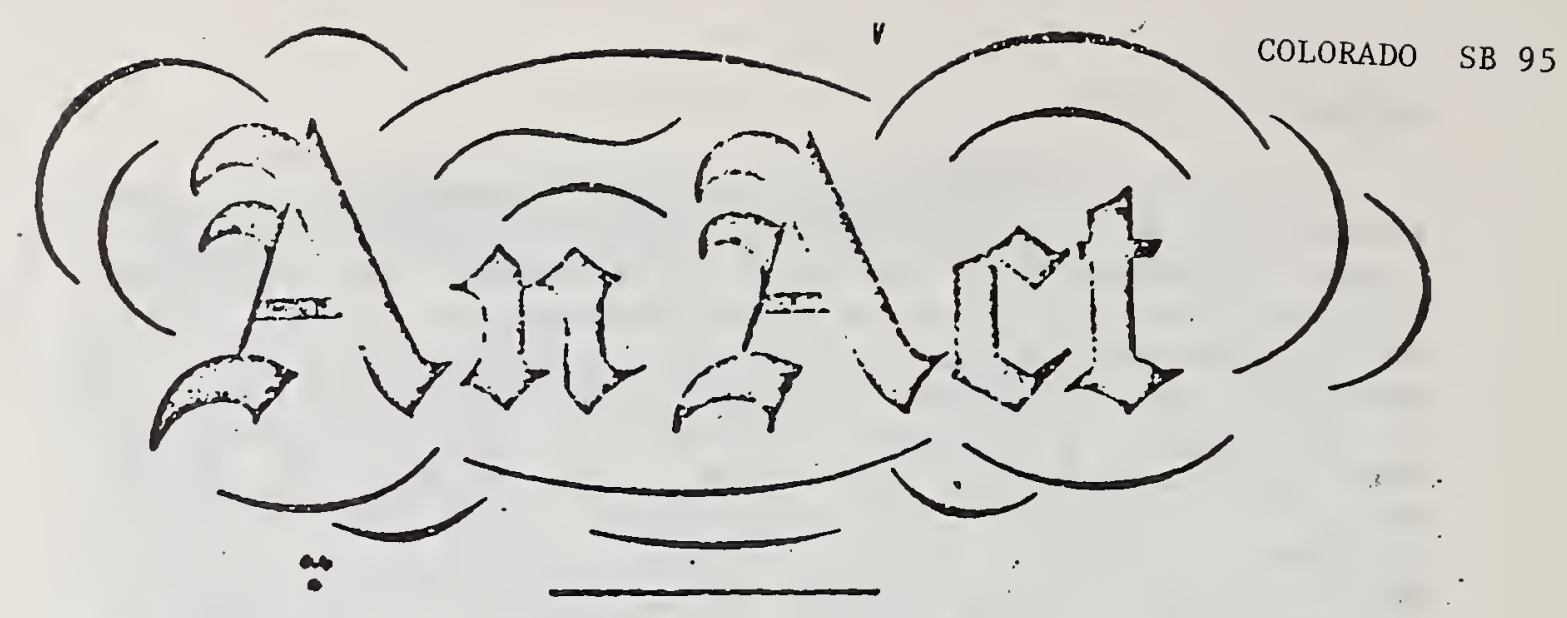

SEMTE BILL :D. S5. BY SENTCRS Schieffelin, Allshouse, Anderson, Fishop, Cocper, DeBcrard, liolis, itughes, Kadlecek,

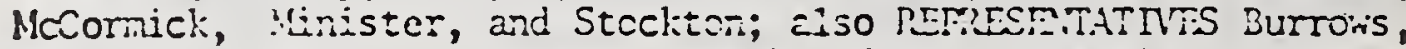
Cantrell, Elliott, Eianer, Frank, Gaon, Hilsmeier, Orten, Shoemaker, and Taylor.

CONCERVIIU SOLAR EASERENTS, AND PFOVIDIMG FOR TIE CREATINN AND

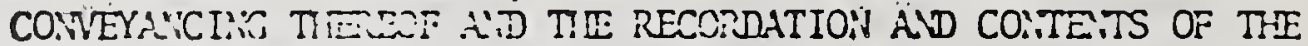
INSTRUEAT RELATI:A TIEETO.

Be it enacted bv the General Assembly of the State of Colcrado:

SECTION 1. Title 38, Colorado Revised Statutes 1973, as. amended, is atiended BY THE ADDITION OF A NEV ARTICLE to read:

\section{ARTICLE 32.5 \\ Solar Easements}

38-32.5-101. Solar easements - crestion. Any easement obtained for the purpose of expostire of a SOLar energy device shall be created in writing and shall be subject to the sane conveyancing and instrunent recording requirements as other easements.

38-32.5-102. Contents. (1) Any instrment creating a solar easencnt shallincllice, but the contents shall not be linited to:

(a) The vertical and horizontal angles, expressed in degrees, at which the solar easement exterds over the real property subject to the solar easement;

(b) Any terms or conditions or both under which the solat

Capital letters indicate new material added to existing statutes; dashes throush words indicate deletions from existing statutes and such material not part of act. 
eascrient is granted or will be terminated;

(c) Amy provisions for comensation of the arner of the property benefitting from the solar eascment in the ciant of interference with the enjoyment of the solar easement or compensaticn of the anner of the property subject to the solar caserent for maintaining the solar eascinent.

SECTION 2. Safetv clause. The general assembly hereby finds, detcmincs, anic deisires that this act is necessary for the imediate preservation of the public peace, health, and safety.

Fred T. Ancerson

PRESIDEVT OE

THE SEVHTE
Ruben A. Valcez

SPEAIJR OF TE: 'DIISE:

OF REPRESETTATIVES

Evelyn T. Davicson

CHIEF CLERK OF THE IOSISE

OF REPRESEVIATIVES
SECRETARY OF

TIE SEWTE

PAGE 2-SENITE BILL 10.95 
AN ACT relating to solar encresy, creating a solar energy center, authorizing rescirch, dissemination of information, and providing demonstrations, providing an eifective date.

WHEREAS, the energy demands of Florida are presently growing at a rate which would rejuire hy the year 2000 six (6) times as much energy as currently needed; and

WHEREAS, the energy resources currently supplying the stilte's demands are both becoming increasingly scarce and nore costly; and

WIEREAS, the adverse environmental effects associated with the production, transportation and utilization of present energy resources are degrading the high level of environmental quality of the state; and

WHEREAS, solar energy represents a vast potential energy resource for the people of the state; and

WHEREAS, it is in the interest of Florida to utilize to the maximum extent possible the significant capahilities already existing within the universities of the state; and

WHEREAS, this increased research and public knowledse is needed to aid in the realization of this potential; NOW THEREFORE,

Be It Enacted by the Legislature of the State of Floida:

Section 1. Board of Regents to develop solar energy center plan.

(1) The legislature hereby directs the board of regents of the state university system to develop a plan for a solar ener $\because *$ center and present the plan to the legislature by Ifarch 1, 1975. The center shn!l be termed to advance research and development in solar energy, to disseminate information on the results of such research, and to engare in projec:s designed to exemplify the capability of solar energy as a resource for meeting state energy needs. The plan shall include:

(a) a proposed location for the conter selected after consileration or centers of present technical expertise, availability of equipment and facilities, convenience of location to all of Florida, and other relevant factors,

(b) an organizational structure for the center to allow personnel from all institutions within the state university sy $s$ tem and crier $=$ in participate in center activities, and also to provide the ability to actireiy seek federal and other funds to support the work of the center and to coordinate cooperative solar energy research efforts within the state university system,

(c) a program proposal and budget for the center which shall cover staff requirements, capital equipment aç̣tisition, buildinss and associated facilities and other costs necessary to carry out the intent of this act,

(d) a program to provide ongoing educational services for persons desiring solar enermy teclunicil knowledge at the morking applications level and at levels requiring high technical competence,

(e) a program to develup methods for testing solar equipment,

(f) a program to develop and participate in demonstration projects and in the design and development of solar energy systems with empiasis on incident solar energy applications,

(g) a program to develop and disseminate information and to maintain an information system on solar eneryy and solar products, and

(h) a program to provide technical ansistance to state agencies in the development of infurmation and standirds in the field as required.

Section 2. Effective Dalte.-This act shall take effect on July 1, 19-4.

Approved by the Governor June 17, 197\%.

Filed in Office Secretary of State June 18, 1974. 
$\therefore$ bill =i b? entiLled

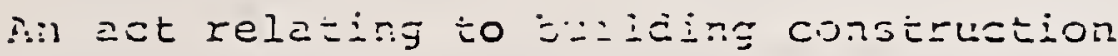

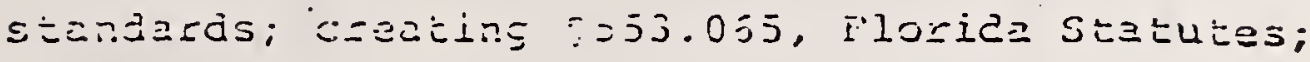

pニoviding that no duilding be constructed with-

Out provision Ior IUtuze installation ó solar .

hot rater heating eg'innani; providing an: :

e乏‡ective date.

11 Be It Enacied by the Iegislature of the Siate of Florida:

12

Section 1. Section 553.065, Floride Statutes, is

14 created to read:

- 553.055 Notwitistaneing the provisions of. 59553.12 and

i6 553.13, no single Ianily residence shall be consinucted within

17 the state, ulless the pluning therein is designed to facili-

$1 \dot{8}$ tate the future installation of solar vater heating equipment.

19 The words "Iacilitate the Iuture installation" as used in this act shail nean the provision of readily accessible piping to :allo' for pipe fittings that will allow easy future connection

22 into the system of solar water heating equiprent. It is the

23 intent of the legislature to minimize cost of rearranging

24 Dlumbing should solar vater heaters be added to buildings.

Section 2. This act shall ta'e effect october 1, 1974. 
(lo be made one and twelle coppes)

THE SHNATE

EIGHTH L.EGISLATL'RE, 1975.
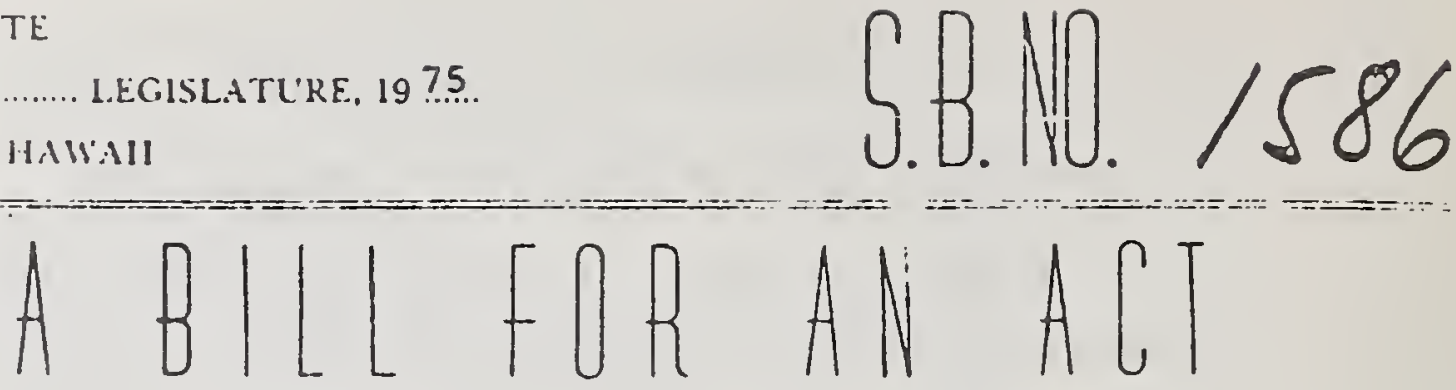

¿ATIYO AN APPRGPRIATION FOR RESEARCH AND DEVELOPMENT OF D.LTERNATE ENERGY SOURCES FOR HAWAII.

\section{BE IT ENACTED BY THE LEGISLATURE OF THE STATE OF HAWAII:}

1 SECTION 1. There is appropriated out of the general revenues 2 Of the State of Hawaii the sum of $\$ 882,000$ and out of general 3 obligation bond fund the sum of $\$ 905,000$, or so much thereof as 4 ray be necessary, for the funding of applications and demonstrations,

5 research and energy institution programs directed toward the clevelop6 ment and utilization of alternate energy sources. The areas pro7 posed for funding are based on recommendations for the Committee

8 on Alternate Energy Sources for Hawaii, the University of Hawaii

9 Planning Committee for the National Energy Institute, and the

10 Marine Affairs Coordinator. The purposes of the funding are for:

I)

A. Applications \&

13 Demonstrations

I4 Hydroelectric

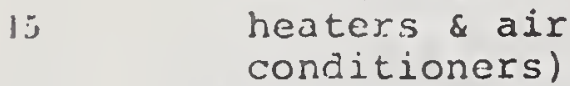

lii B. Research \& Development

17

Ix

Funding $(\$ 1,000)$ Source of

75-76 $16-77$ Funding

Solar (water

75

50

120

150

150

OTEC

Bioconversion

--
30

50

80

200

150

40
Go Bonds

GO Bonds

Go Bonds

co Bonds

Gen. Fund

Gen. Fund 
C. Institutional support

iawail Natural

Energy Institute

Hawai Natural

Energy Laboratory

Gen. Fund

Go Bonds

GO Bonds

Gen. Fund

905 Bienniun
882 Biennium
1,787

SECTION 2. The sum appropriated shall be expended for the

6

7 8 9 10 i i

$2 \cdot 1$

25

7

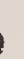

purpose of this Act by the department of planning and economic deveiopment. The state energy resources coordinator, who is the department director, shall contract with the University of Hawai, and other state and private agencies to carry out the proposed work. Federal matching funds will be sought for projects where feasible. SECTION 3. This Act will take effect on July 1, 1975.

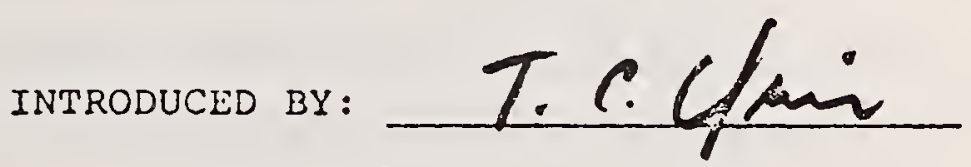




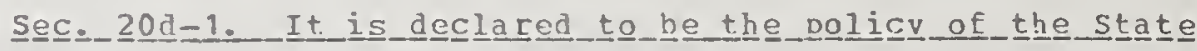

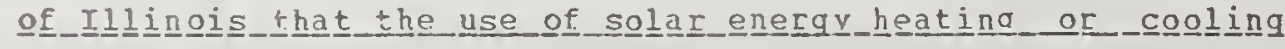

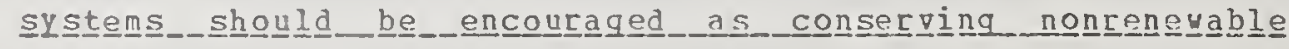

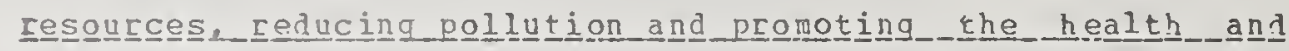

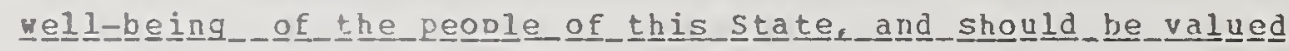

(Ch. 120, new par. $501 d-2$ )

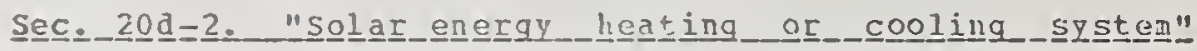

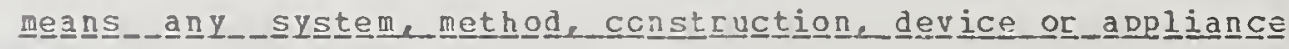

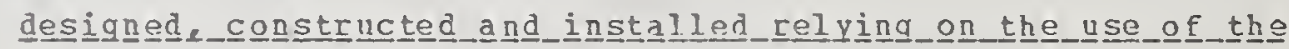

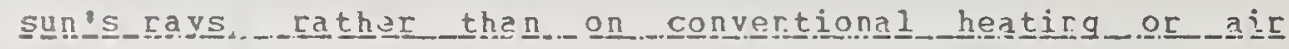

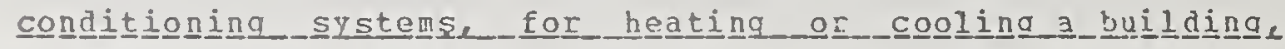

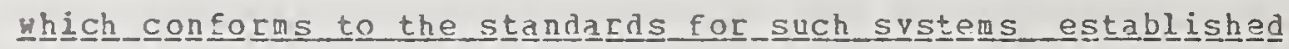

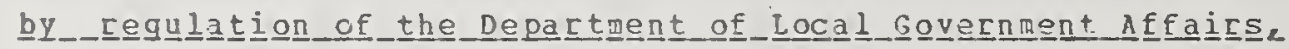

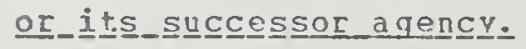

(Ch. 120, new par. 501d-3)

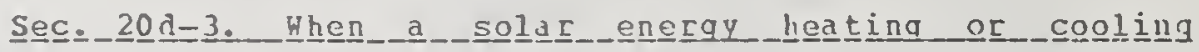

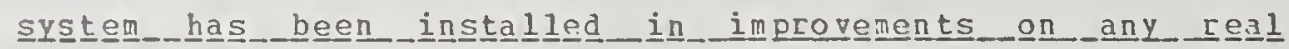

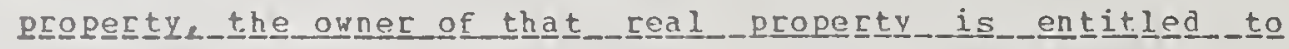

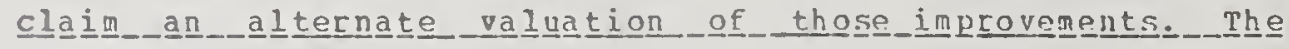

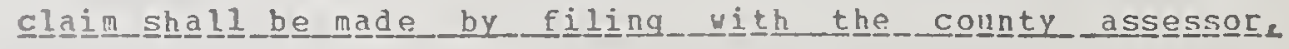

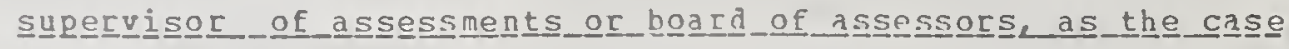

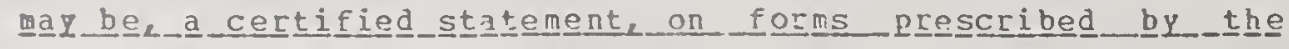

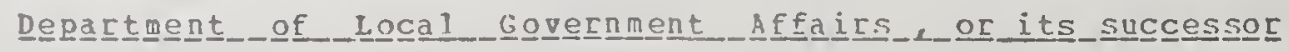




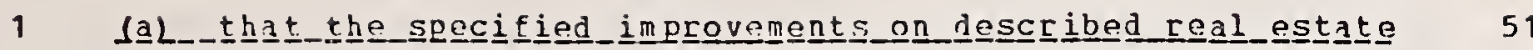

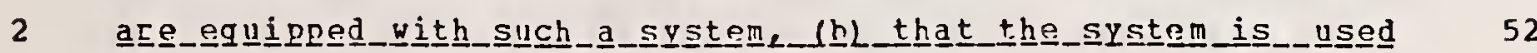

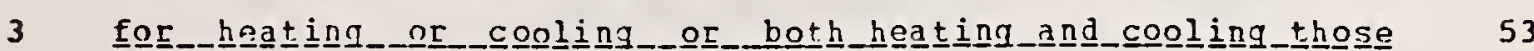

4 im

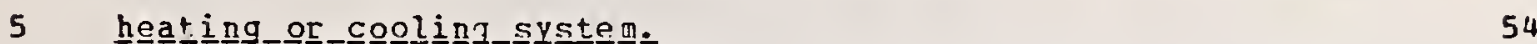

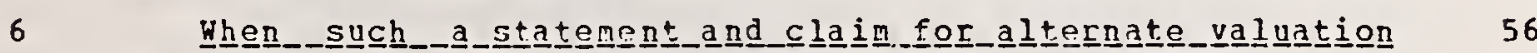

7 is

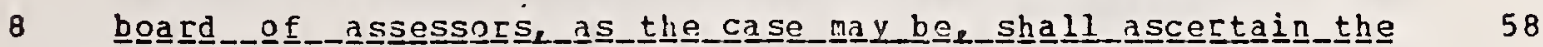

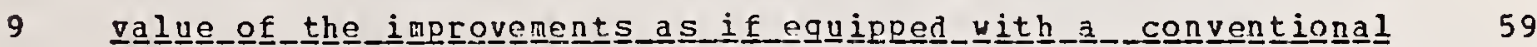

10 heating _or c cooling

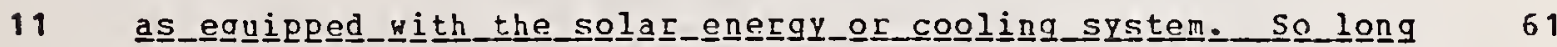

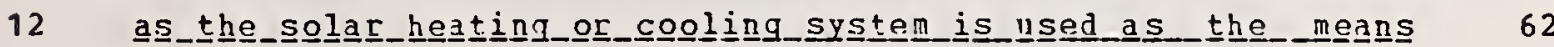

13 으 _heating

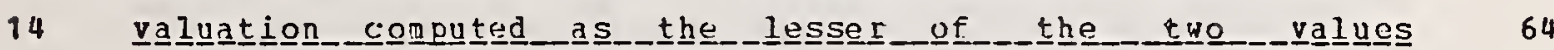

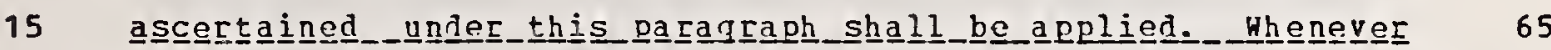

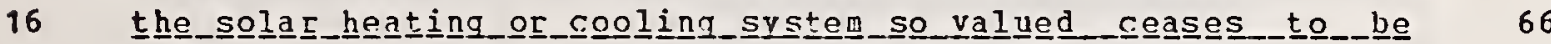

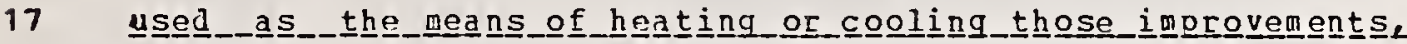

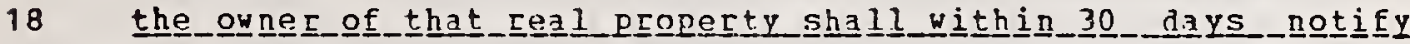

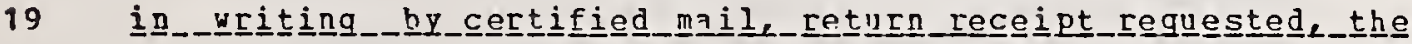

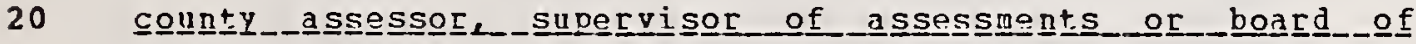

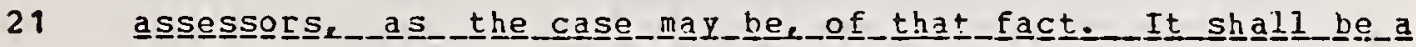

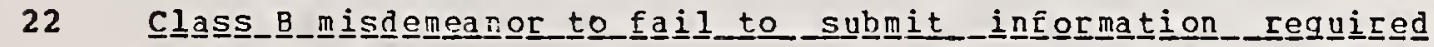

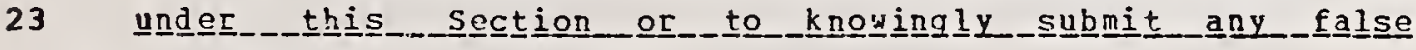

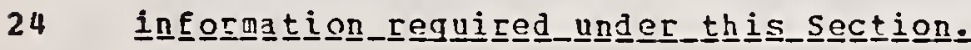


Public Liaw No. 15

[S. 223. Approved February 18, 1974.]

AN ACT to amend IC 1971, 6-1 by adding a new chapter concerning property tax deductions for solar energy systems.

Be it enacted by the General Assembly of the State of Indiana:

SECTION 1. IC 1971, 6-1 is amended by adding a new chapter 9.5 to read as follows:

Chapter 9.5. Deduetion-Solar Energy Systems.

Sec. 1. The owner of real property which is equipped with a solar encrgy heating or eooling system may have deducted annually from the assesser valuation of the real property a sum whieh is equal to the lesser of:

(1) the remainder of (i) the assessed valuation of the real property with the solar heating or cooling system included, minus (ii) the assessed valuation of the real property withont the system; or

(2) two thousand doinar's $(\$ 2,000)$.

Sec. 2. The owner of real property who desires to claim the deduetion provided in this chapter must file a certified statement in duplieate with the auditor of the county in whieh the real property is loeated. In addition, the owner must file the statement on forms preseribed by the state board of tax commissioners, and he must file the statement between Mareh 1 and May 10, inelusive, of each year for whieh he desires to obtain the deduetion. Upon verifieation of the statement by the assessor of the tornship in whieh the real property is loeated, the eounty auditor shall make the deduetion. 
Riv ACT

TO CREATE AIJ EINERGY RESEARCí AITD DEVELOPMEUT FUND WITIIIN THE ENERGY POLICY COUNCIL AND HAKING AN APPROPRIATION.

BE IT EIJACTED BY THE GEUERAL ASSEMBIY OF TIL STATE OF IOWA:

Section 1. Chapter ninety-three (93), Code 1975, is amendel by adding the following new sections:

NES SECTION. ENERGY PESEARCH AND DEVELOPMENT FUIJ. There is created within the council an energy research and development fund. Moneys deposited in the fund shall be used for the research and development of projects designated to improve Iowa's energy situation by developing improved methods of energy conservation, by enabling Iowans to better manage available energy resources, or through the increased cevelopment and use of Iowa's renewable or nonrenewable energy resources. Said projects will be selected by the council with the advice of knowledgeable persons appointed by the council to provide assistance.

NEW SECTION. ADDITIONAL FUNDS. The council may accept funds from state and local sources and shall take steps necessary to obtain federal funds allotted and appropriated for the purpose of the above described energy-related programs. Such funds shall be deposited in the energy research and development fund. Federal funds received under the provisions of this section are appropriated for the purposes set forth in the federal grants.

Sec. 2. There is appropriated from the general fund of the state for the fiscal year commencing July 1,1975 and ending June 30, 1976, to the Energy policy council, the sum of two hundred fifty thousand $(250,000)$ dollars, or so muci thereof as may be necessary, to carry out the purposes of this Act. Any unobligated balance of funds as of June 30, 
1976 appropriated by this section shall revert to the credit of the general fund on August 31, 1976.

ARTIIUR A. IIEU
President of the Senate

DALE M. COCFIRA'J

Speaker of the House

I hereby certify that this bill originated in the senate and is known as Senate File 289, Sixty-sixth General Assembly.

\section{CLARK R. RAS:HUSSE!T}

Secretary of the Senate

Approved 1975

ROBEFT D. RAY

Governor 


\title{
STATE OF MAINE \\ IN THE YEAR OF OUR LORD NINETEEN HUNDRED SEVENTY-FIVE
}

APPROVED

JUN $26^{\prime} 75$

BY GOVERNOR

\section{7}

PUBLIC LAW

\author{
S. P. 549 - L. D. 1913
}

AN ACT Concerning the Office of Energy Resources.

Emergency preamble. Whereas, Acts of the Legislaturc do not become effective until yo days after adjournment unless cnacted as cmergencies; and

Whereas, the Unitcd States is in the initial stages of a far-reaching cncrgy crisis and is secking new and alternative sources of energy; and

Whereas, Maine and the Northeast are dependent upon expensive foreign oil which has a significant effect on the State and regional economies; and

Whereas, the Federal Guvermment is encouraging the several states to develop energy conscrvation programs and to administer programs to help reduce the scvirity of the energy crisis; and

$$
\text { in }
$$

Whereas, Mainc's Office of Energy Resources is presently not functioning, which has a serious impact un the State and denies the State millions of dollars of fcderal funds for cnergy conservation and developinent; and

Whercas, in the judgment of the Legislaturc. thesc facts create an emergency within the meaning of the Constitution of the State of Mraine and require the following legislation as immediately neccssary for the preservation of the public peace, health and safety; now, therefore,

Be it enacted by the People of the State of Maine, as follows:

Sec. I. 5 MRSA § 5004, as cnacted by PL 1973, c. 770, § 2, is repealed and the following cnacted in place thercof:

\section{$\S$ 5004. Director of Office of Energy Resources}

I. Appointment. The Governor, with the approval of the Executive Council, shall appoint a full-time Director of the Office of Energy Resources. The director shall serve a term coterminous with that of the Governor and until his successor is appointed and quaiified, subject to removal for cause by the Governor. The director shall be paid a salary fixed by the Governor and Council.

2. Qualifications. The Director of the Office of Energy Resources shall have a background in engineering, econonics, energy rescarch or the administration of energy programs and shall be qualified to evaluate energy conservation or development proposals in terms of technical and economic feasibility.

3. Powers and duties. The director shall exercise the powers of the office and shall be responsible for the execution of its duties. The director shall: 
A. Administer the office and adopt such methods of administration, not inconsistent with the law, as lie may determine necessary to render the office efficient;

B. Appoint and remove the staff of the office and prescribe their duties as may be necessary to implement the purposes of this chapter. Professional employees shall be hired as unclassified employees. All other employees shall be subject to the Personnel Law.

C. Be assisted by the New England Power Pool and by departments, agencies, authorities, boards, commissions and other instrumentalities of State Government in the gathering of information, reports and data which relate to state planning and development in the area of energy resources;

D. Prepare and submit for executive and legislative action thereon the budget for the office;

E. Be empowered, in connection with the performance of his duties, to apply to the Superior Court for a subpoena to compel the attendance of witnesses, the production of books, papers, records and documents of individuals, firms, associations and corporations and all officers, boards, commissions and departments of the State. Said court shall, before issuing such subpoena, provide adequate opportunity for the director and the party against whom the subpoena is requested to be heard. No such subpoena shall be issued unless the court or judge certifies that the attendance of such witness or the production of such books, papers, records or documents is reasonably necessary to carry out the purposes of this section and that the director has made reasonable efforts to secure such attendance or such books, papers, records or documents without recourse to compulsory process. The director shall afford confidential treatment to any materials or information turned over to him which is of a confidential or proprietary nature.

F. Be responsible for the coordination of all state energy programs and the coordination of state programs with progranis and plans developed by private organizations and the Federal Government.

G. Be responsible for the administration of all federal energy programs to be implemented in Maine. This includes, but is not limited to, the Fuel Allocation and Conservation Program and all related activities.

H. Be responsible for the dissemination of energy related information to the public. Upon request, the airector shall provide information to public and private groups in the field of energy.

I. Be responsible for the formulation of a comprehensive state energy resources plan and a state energy policy.

4. Annual report. The Director of the Office of Energy Resources shall prepare an annual report to be presented to the Legislature in every regular and special session of the Legislature. The annual report shall include, but is not limited to, the following: The programs developed and implemented by the Office of Energy Resolires, the stage of development of the programs. the stage of implementation of the State Energy Plan and the direction of programs planned for the ensuing year.

Sec. 2. 5 MRSA $\$ 5005$, as cnacted by PL 1973, c. $770, \$ 2$, is repealed and the following enacted in place thereof:

\section{$\S 5005$. Office of Energy Resources}

I. Powers and duties. The Office of Energy Resources shall:

A. Prepare a comprehensive energy resources plan to be revised and updated at least annually and moie often as the Director of the Office of Energy Resources or the State Legislature deem necessary.

SSI-2 
(1) The comprehensive plan shall include, but is not limited to, a description and quantification of the present supply, rates of use and energy needs of the State; a description and quantification of the projected needs, rate of usc and availablility of various energy resources to meet future state needs; a cost analysis of providing energy to meet the state's future needs; a description of the assumptions upon which the predictions and costs are based and the probability of error in the projections in the plan;

B. Prepare a state energy policy to include, but is not limited to, the following: The direction or directions most feasible for Maine to pursue in the field of energy resource use and development, feasible alternatives to implement the state energy plan and long range as well as short range energy programs;

C. Encouragement of voluntary energy conservation among state and local government, industry, business and the public for the most efficient utilization of available energy;

D. The Director of Energy Resources shall be responsible for collecting and analyzing energy data from all available energy sources in and outside the State;

E. Provide technical assistance to the Governor and the Legislature in identifying the emergency and long-range needs and resources to meet these needs for the State;

F. Upon request, provide planning and technical assistance to public and private groups in the field of energy planning;

G. Encourage and direct or sponsor research and experiments within the State to develop alternate energy sources, particularly, but not limited to, those sources which rely on the renewable natural resources of the State, such as the water of the tides and rivers, the forests, the winds and other sources which to date have not been fully explored or utilized;

H. Encourage and direct, in conjunction with private industry, the practical development and operation on a small scale of experimental projects involving alternate energy sources, in order to ascertain the potential usefulness of such alternate energy sources and their costs, provided only that such projects shall be subject to the regulations of those state agencies concerned with the protection of the environment and preservation of the natural resources of the State, and with regulation of other energy sources;

I. The Office of Energy Resources. with the consent of the Governor, may emp.oy such expert and professional consultants as it deems necessary within the limit of funds available and consistent with the powers and duties of the office.

Sec. 3. 5 MRSA $\S 5006$, as culicted by PL 1973, c. 770, $\$ 2$, is repealed and the following enacted in place thereot:

\section{$\S$ 5006. Maine Energy Resources Development Fund}

All federal and private moneys received by the Office of Energy Resources for enersy research and development shall be deposited in the Maine Energy Resources Development Fund. The Maine Energy Resources Development Fund shall be administered by the Director of the Office of Energy Resources and shall be used only to carry out the provisions of this Act. The Office of Energy Resources shall be the designated state agency to handle all energy matters within the State which are not the specific responsibility of another state agency under the provisions of federal or state law, and authority is conferred on the director of sucl office to accept, use and administer all energy funds, including fecleral, state and private funds, 
in accordance with established budgetary procedures which become available pursuant to this Act. The director may receive on behalf of the Office of Energy Resources or on behalf of the State any grants or gifts and may accept them.

I. Report to Legislature. The Director of Energy Resources shall report annually to the Legislature in January of every regular and special session of the Legislature in regard to expenditure of funds, the purposes for which said funds were used and the amount of as well as the sources from which the funds were derived.

Sec. 4. 5 MRSA $\S 5007$, as enacted by PL 1973, c. 770, $\S 2$, is repealed and the following enacted in place thereof:

\section{§5007. State Energy Resources Advisory Board}

1. Appointment. The Governor shall appoint a State Energy Resources Advisory Board to advise the Governor, the Legislature and the Director of the Office of Energy Resources on policy matters relating to this chapter.

2. Membership. The State Energy Resources Advisory Board shall consist of the following: One member of the House of Representatives to be appointed by the Speaker of the House and one member of the Senate to be appointed by the President of the Senate and one representative of the Public Utilities Commission and with said Legislators to serve ex officio; and the following 6 members to be appointed by the Governor, with the advice and consent of the Council, such members to be selected on the basis of their interest, education and experience in the areas of energy planning, research and development, to include one representative of industry, one representative of labor, one representative of the academic community, 2 representatives of the general public and one representative of the business community.

Sec. 5. 5 MRSA $\S \S 5008$ and 5009 are enacted to read:

\section{§5008. Duties}

The State Energy Resources Advisory Board shall meet at least 3 times each year and at other times at the request of the Director of the Office of Energy Resources or the Governor. The members of the board shall provide information and assistance in the development of a state energy resources plan and in the research and development phase of the office's activities as requested by the director. The board shall act only in an advisory capacity and shall have no power to control the activities of the office.

\section{$\S 5009$. Restrictions on employee interests}

No member, officer or employee of the Office of Energy Resources shall acquire any interest, direct or indirect, in any contract or proposed contract negotiated or proposed by the Office of Energy Resources, nor shall any member, officer or employee participate in any decision or any contract entered into by the authority if he or she has an interest, direct or indirect. in any firm, partnership, corporation or association which will be party to such contract or financially involved in any transaction with the authority.

Emergency clause. In view of the emergency cited in the preamble, this Act shall take cffect when approved. 


\section{SEP $1810 \% 5$}

H O U S E E O P D E L E G A T E S

No. 1604

By: Delacates Zandor, frMaurer, Bell, Docter, Shore and Scul111

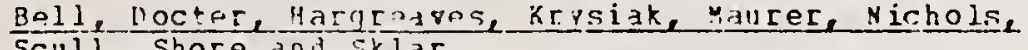

Scul I. Shore and cklar

Introduced and rear first timo: March 3, 1975

Assigned to: Ways and keans

Conittee Report: Favorable with amendments

House Action: Adopted

Bead second time: March 20, 1975

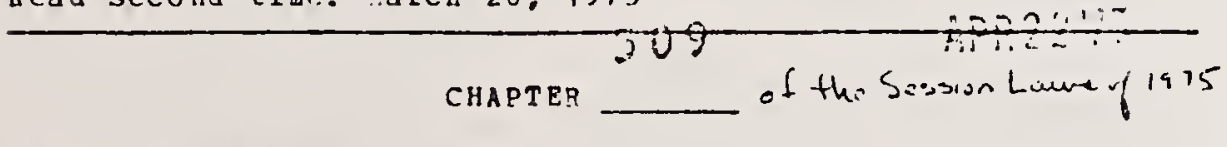

AN ACT concerning

Solar Energy Units - Assessment

POR the purpose of requiring that solar energy heating and cooling units used in certain buildings be assessed in a manner so as to not exceed the assessuent of conventional heating and cooling 51 units.

BY adding to

Article 81 - Revenue and Taxes

Section 14 (b) (4)

Annotated code of Maryland

(1969 Replacement Volume and 1974 Supplement)

SECTION 1. BE IT ENACTFD BY THE GENRRAL ASSEMBLY OF AARYLARD, That new section 14 (b) (4) be and it is hereby added to Article 81 - Revenue and Taxes, of the Annotated Code of Maryland (1969 Replacenent volume and 1974 Supplenent) to read as follows:

$$
\text { Article } 81 \text { - Revenue and Taxes } 71
$$

14.

(b) Except as hereinafter provided: 78

(4) IN ORDER TO ENCOURAGE THE USE AND 80

EXPLANATION: CAPITALS INDICATE MATTER ADDPD TO BXISTING LAH.

[Brackets] indicate atter deleted from existing lay.

Underlining indicates ayendaents to the bill.

[r. Doulle brackets 11 enclose mattor stricken out of hill.

Numerals at right identify computer lines of text. 
I ASTALLATION OP SOLAP FLEFGT HEATING AND COOLTNG INITS IN RI EXISTING OR NEHLY CONSTRIICTED BIILDTNGS, SOLA? FVEFGY R2 HUTTIS AND CCOIIIG UNITS IA PESIRFHTIAL R? NINPESIDENTIAL BUILDINGS SHALL BE ASSFSSPD AT NO MOPR THAN TIE VALUE OP A COIVPNTIONAL HEATING AN C COOLIUG UEIT YECRSSARY TO SERVE THE EUILDING.

SECTION 2. AND BD IT FORTHER PNACTED. That this ACt shall take effect July 1, 1975.

In corod:

Governor.

Speaker of the House of Delegates.

President of the senate. 
A resolution creating a special committee to study the feasibility of statewide use of solar heating and cooling systems.

Whereas, As prices of conventional fuels have increased, interest has turned to utilizing alternative resources to fossil fuels in meeting heating and cooling needs. One resource that has drawn considerable attention has been solar energy; and

Whereas, Solar energy can be collected and converted into useful energy with a minimal impact on the environment and in many cases with no significant waste. It is estimated that by the year 2020 at least twenty percent of the United States total energy needs could be met with solar energy processes; and

Whereas, In light of the need for alternative energy resources, it.is incumbent upon this legislative body to thoroughly examine the feasibility of statewide use of solar heating and cooling systems. There is a need for an extensive historical analysis and review of research on solar energy performed to date and a need for an analysis of present and potential applications; now therefore be it

Resolved, That there is created a special committee of the House to consist of five members to be appointed in the same manner as standing committees are appointed, to function during the 1975-1976 Regular Sessions of the Legislature, to study the feasibility of statewide use of solar heating and cooling systems, and to report its findings and recommendations to the Legislature not later than January, 1977; and be it further

Resolved, That the committee may employ such consultants, aides, and assistants as it deems necessary to conduct its study; the committee may call upon the Legislative Service Bureau, subject to approval of the Legislative Council, for such services and assistance as it deems necessary and may request information and assistance from state departments and agencies; and be it further

Resolved, That the members of the committee shall serve without compensation, but shall be entitled to actual and necessary travel and other expenses incurred in the performance of official duties, to be paid from the appropriation to the House of Representatives.

The resclution was referred to the Committee on House Policy.

\section{COMMITTEE MEMBERS}

Rep. Lucille H. McCollough, Chairperson

7517 Kentucky Street

Dearborn, Nichigan 48126

Phones: Home (313) 934-2575 Business (517) 373-0847

Rep. Thomas J. Anderson

13726 Sycamore Street

Southgate, Michigan 48192

Phones: Home (313) 284-6889

Business (517) 373-0855

Rep. Dan Angel

312 Crary Drive

Marshall, Michigan 49068

Phones: Home (616) 731-4640

Business (517) $373-0830$
Rep. Harold J. Scott

3526 Blue Lake Drive

Flint, Michigan 48506

Phones: Home (313) 744-0417

Business (517) 373-1777

Rep. Robert A. Welborn

2528 Rambling Road

Kalamazoo, Michigan 49008

Phones: Home (616) 344-6886

Business (517) 373-1774 


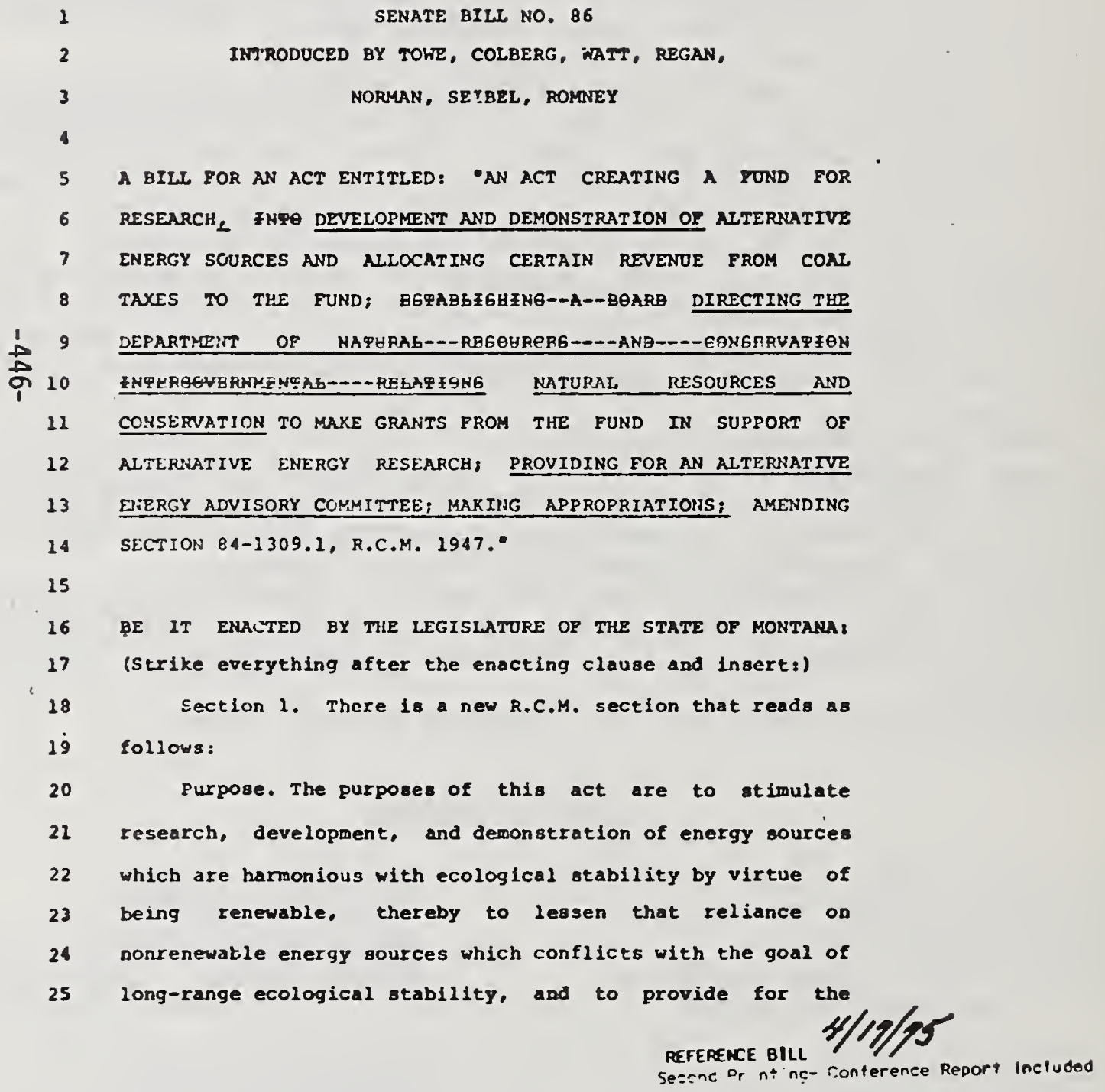


funding and adninistration of such research, provided, that demonstration or development profects funded under this act may. not be used to commerclally market electricity, heat energy, or energy by-products.

Section 2. There is a new R.C.M. section that reads as follows:

Definitions. As used in this act:

(1) "Alternative renewable energy source" means a form of energy or matter, such as golar cnergy, wind energy, or methane FROM SOLID hASTE, capable of being conrerted into forms of energy useful to mankind, and the technology necessary to make this conversion, when the source is not exhaustible in terms of this planet and when the source or the technology are not in general comersial use.

(2) "Person" means a natural person, corporation, partnership, or other business entity, association, trust, foundation, any educational or scientiflc institution, or any governmental unit.

(3) "Department" means the Montana department of naturat---resoureeg---and---eenservation INQERSOVERMMEHQMb RESAI IONG NATURAL RESOURCES AND CONSERVATION.

Section 3. There is a new R.C.Y. section that reads as follows:

Alternative energy research development and demonstration account established. There is within the 


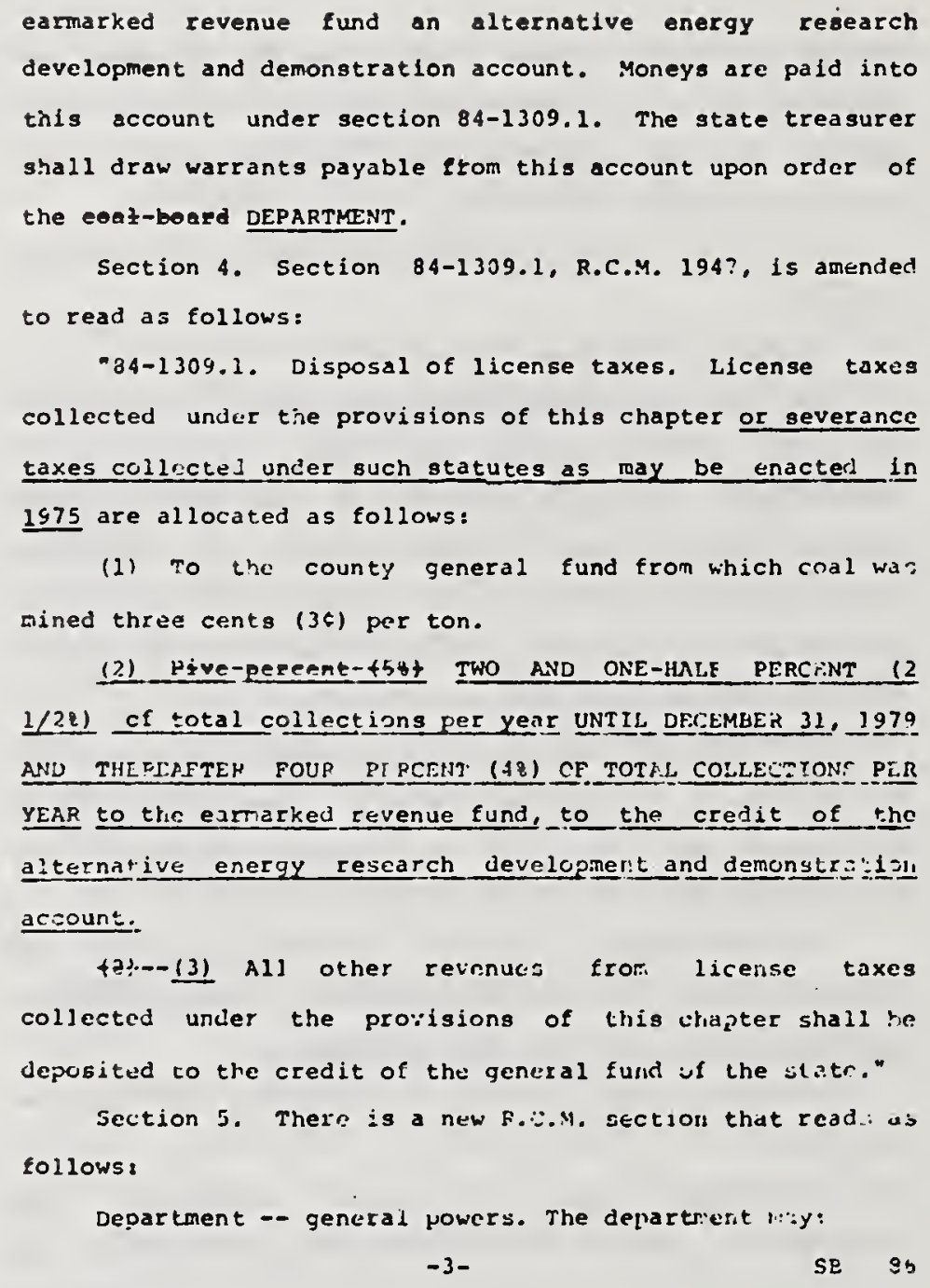


(1) employ a staff adequate to administer this act;

(2) retain professional consultants and adisors;

(3) adopt rules governing applications and granting of fund 8 ;

(4) consider applications for grants and award grants, subject to the avallability of funds, and to tie approptiation of such funcs by the legislasure frcit the alternative energy rasearch development and densnstration funds for projects that will further the purposes of this act;

(5) appoint on ditexnato ife energy advieory comitiel conjosed ot represertitives of state agencies anc citizer: mernhers with expertise in alternative energy matters. The appointmcit of any such asisory sormittec small te in reeping with scction $82 \lambda-1: 0$.

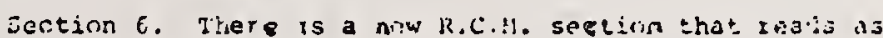
follow:

Apjidications for grouts. Any persen nay apply esr a grant to enable nin (w research, develop or deronszrate a) tiznative renewalde encryy srourc: a The department stid prescribe the form for appications. Applicants stidis

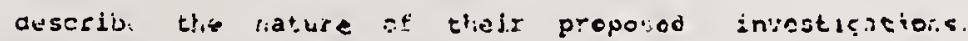
ineluding practicai al ilica:icns of the possible results and tjene requirements.

Seclion 7. There is a new k.C.M. section that rests as $-4-$ 


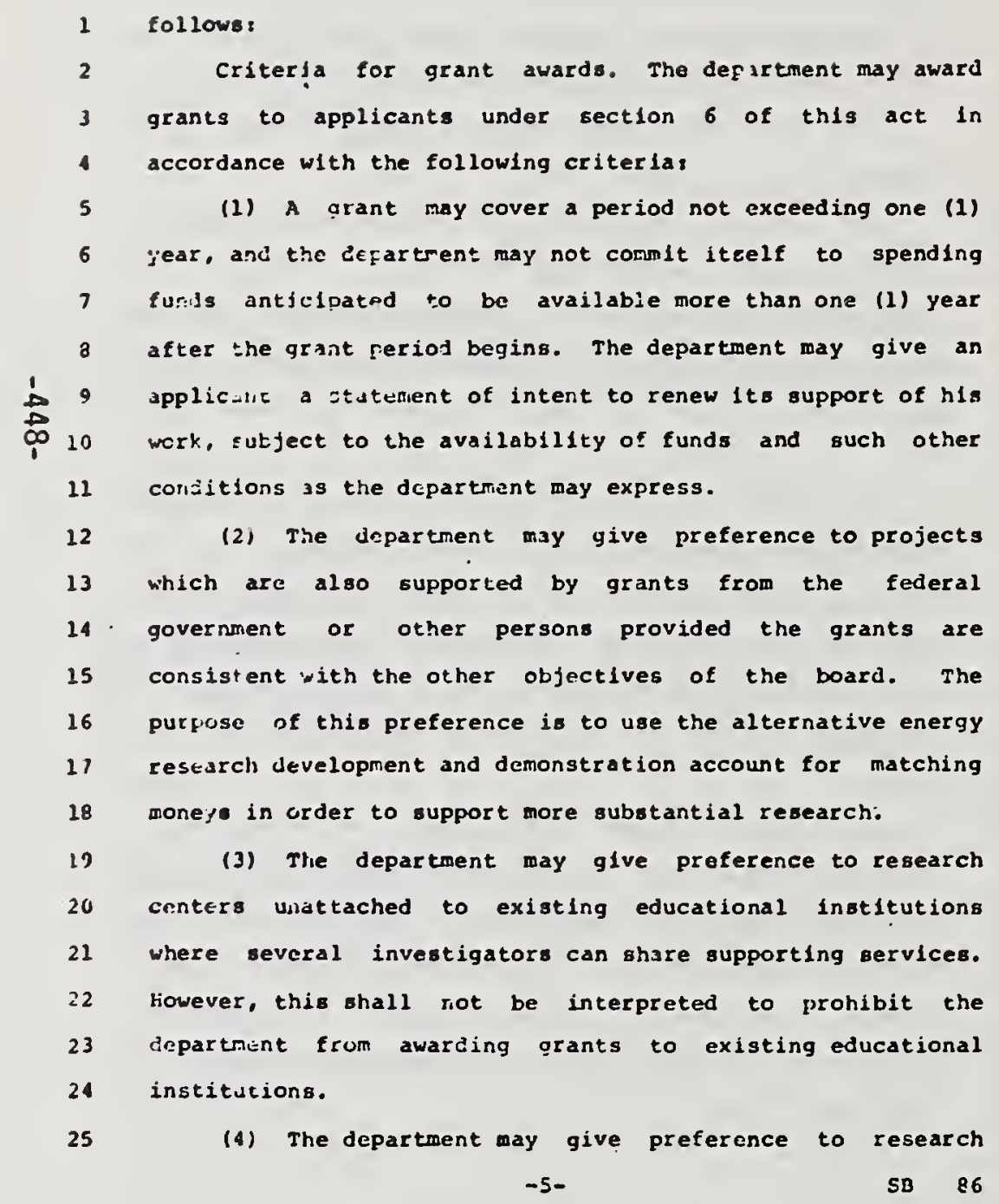




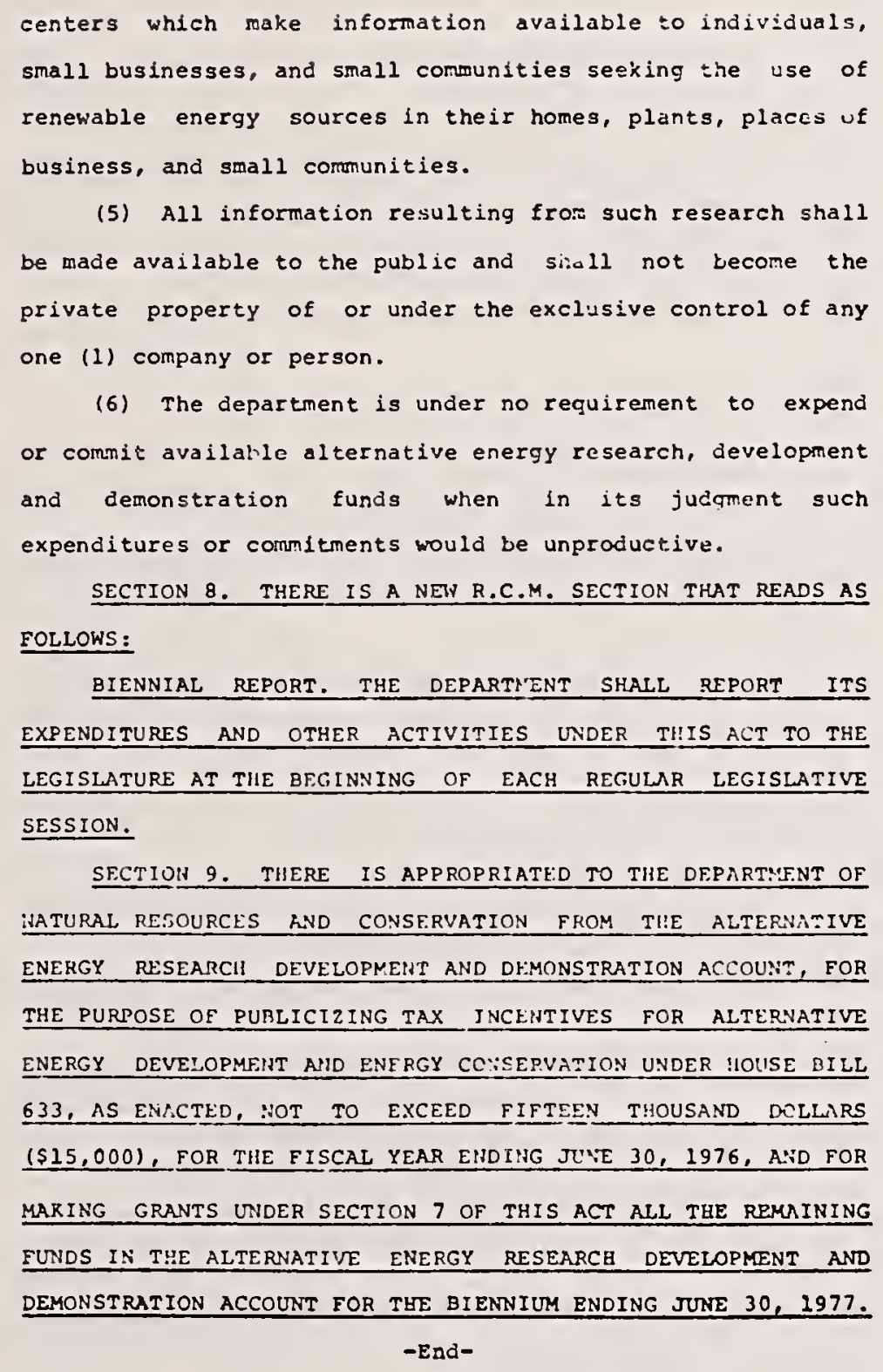




\section{CHAPTER NO. 548}

AN ACT TO ENCOLRAGE INVESTMF.NT IN NONFOSSIL FORMS OF ENERGY GENERATION AND IN E.NERTY CONSFRVATION IN BUILDINGS THROLGH TAX INCENTIVES AND CAPITAL AVAILABILITY, ANENDINC SECTIONS 84-202 AND 84-301, R.C.M. 1947.

\section{Be it enacted by the Legislature of the State of Montana:}

Section 1. There is a new R.C.M. section numbered 84-7401 that reads as follows:

84-7401. Statement of purpose. The purpose of this act is to encourage the use of alternative energy sources and the conservation of energy through incentive programs. Such incentives are to be made available to the energy user on a basis which requires hin to take the initiative in obtaining a particular incentive. This act is not intended to require in obtaining a particular ince property except upon receipt of a properly documented and approved application. This act allows but does not require a pubiic utility to extend credit for energy conservation investments.

Section 2. There is a new R.C.M. section numbered 84-7402 that reads as follows:

84-7402. Definitions. As used in this act:

(1) "Building" means a single or multiple dwelling, including a mobile home, or a building used for commercial, industrial, or agricultural purposes, which is enclosed with walls and a roof.

(2) "Capital investment" means any material or equipment purchased and installed in a building, or land, with or without improvements.

(3) "Energy conservation purpose" Ineans one or more of the following results of an insestment: reducing the: waste or dissipation of energy, or reducing the amount of energy required to accomplish a given quantity of work.

(4) "Recognized nonfossil forms of energy generation" means a system for the utilization of solar heat, wind, solid wastes or the decomposition of organic wastes, for capturing energy or converting energy sources into usable sources, for the production of electric power f rom solid wood wastes, and also means a small system for the utilization of water power by means of an impoundment not over twenty (20) acres in surface area.

Section 3. There is a new R.C.M. section numbered $84-7403$ that reads as follows:

84-7403. Tax treatment of certain energy-related investments. (1) Upon application by a taxpayer, approved under section 84-740.4, a capital investment by the taxpayer in a recognized nontossil form of energy generation shall be treated by the department of revenue as:

(a) property exempt from taxation, to the extent the appraised value of the investment does not exceed one hundred thousand dollars $(\$ 100,000)$, or

(b) class seven property, as defined in sections 84-301 and 84-302, for. such portion of the appraised value of the investment that exceeds one hundred thousand dollars $(\$ 100,000)$.

(2) Upon application by a taxpayer, approved under section 84-7404, a capital investment in a building by the taxpayer for an energy conservation purpose shall he treated by the department of revenue as class eight property, as defined in sections 8.1-301 and 84-302, to the extent the appraised value of the investment does not exceed twenty percent $(20 \pi)$ of the appraised value of the building in which the investment is made.

Section 4. There is a new R.C.M. section numbered 84-7404 that reads as follows: 
84-7404. Application for special energy investment taxation. The department of revenue shall provide forms on which a taxpayer may apply for tax treatment under section $84-7403$. Application shall be made to the department. The department shall approve an application which demonstrably promotes energy conservation or utilizes a recognized nonfossil form of energy generation. The department may refer an application involving energy generation to the department of natural resources and conservation for its advice, and the department of natural resnurces and conservation shall respond within sixty (60) days. The department may refer an application involvine enerey conservation to the department of adninistration for its advice, and the department of adninistration shall respond within sixty 160$)$ days. The department of revenue mily deny an application which it finds to be inipractical or ineffective.

Section 5. There is a new R.C.M. section numbered 84-7405 that reads as follows:

8.1-7.405. Capital may be lent by utilities - tax credit for interest differential. (1) $A$ public utility providing electricity or natural gas may install or pay for the installation of energy conservation materials in a dwelling. The utility may agree with the occupant of the dwelling that the occupant shall reimburse the utility for its expenditure in periodic installment payments added to the occupant's regufur bill for electricity or nitural gas. The utility may chatrge interest not exceeding the equivalent of a rate of seven percent $(7 \%)$ per year on the declining balance of the sum advanced.

(2) A public utility lending money under this section may compute the difference between interest it actually receives on such transactions and the interest which would have been recewed at the prevailing average interest rate for home improvement loans. as prescribed in rules made by the public service commission. The utility may apply the difference so computed as a credit against its tax liability for the electrical energy producer's license tax under section 84-1601 or for the corporation license tax under section 84-1501.

(3) The public service commission may make rules to implement this section.

- Section 6. There is a new R.C.M. section numbered 84-7406 that reads as follow:s:

84-7406. Limitations. Tax treatment under section $84-7403$ is limited to:

(1) capital investments made after January 1, 1975, and

(2) persons and firms not primarily engaged in the provision of gas or electricity derived from fossil fucl extraction or conventional hydroelectric development, and

(3) a ceiling of one hundred thousand dollars $(\$ 100,000)$ in tax savings per year to any one person or firm

Section 7. Section 84-202, R.C.M. 1947, is amended to read as follows:

"84-202. Exemptions from taxation. (1) The property of the United States, the state, counties, cities, towns, school districts, municipal corporations, public libraries, such other property as is used exclusively for agricultural and horticultural socicties, for educational purposes. places of actual religious worship, hospitals and places of burial not used or held for private or corporate profit, and institutions of pureiy pubilic charity, evidence of debt secured by nortgages of record upon real or personal property in the state of Montania, and public art gaileries and public observatories not used or held for private or corporate profit, are exempt from taxation, but no more land than is necessary for such purpose is exempt; provided, the term "institutions of purely public charity" as used in this act shatl include organizations ownung and operating facilities for the care of the retired or alyed or chronicilly. ill which are not operated for gain or profit; provided, that the terms public art galleries and public observatories used in this act shall mean only such art galleries and observatories whether of public or private ownership. as are open to the public, without charge or fee at all reasonable hours, and are used for 
the purpose of education only, and also when a clubliouse or building erected by or belonging to any society or organizition of lonorably discharged United Stites soldiers, sailors or marines who served in army or navy of United Stites, is used exclusively for educational, fratermal. benevolent or purely public charitable purposes, rather than for gain or profit, logether with the liblary and funiture necessarily used in any such building, and all property, real or personal. in the possession of legil guardians of incompetent veterans of the World War or minor dependents of such veterans, where such property is funds or derived from funds received from the United States as pension, compensation, insurance, adjusted compensation, or gratuity, sliall be ex('mpt from all taxation as property of the United States while held by the guardian, but not after title passes to the veteran or minor in his or her own right on account of removal of legal disability.

(2) All household groods and furniture, including clocks, musical instruments, sewing machines, wearing apparel of members of the family actually used by the owner for persomal and domestic purposes. or for furnishing or equipping the family residence are exempt from taxation.

(3) Freeport merchandise shall be excmpt from taxation. Freeport merchandise means those stocks of merchandise manulactured or produced outside this state which are in transit through this state and consigned to a warchouse or other storage facility, public or private, within this state, for storage in transit prior to shipment to a final destination outside the state, and which have acquired a taxable situs within the state.

Stocks of merchandise do not lose their status as freeport merchandise because while in the storage facility they are assembled. bound, joined, processed, disassembled, divided, cut, broken in bulk, relabeled or repackaged.

Any person, corporation, firm, partnership, association, or other group seeking to qualify its property for inclusion in this class shall make application to the state department of revenue in such manner or form as may be required by the department.

(4) All unprocessed, perishable fruits and vegetables in farm storage and owned by the producer are exempt from taxation.

(5) A capital intestment in a recognized nonfossil form of energy generation is exentpt to the extent provided under section $84-703 . "$

Section 8. Section 84-301, R.C.M. 1947, is amended to read as follows:

"84-301. Classification of property for taxation. For the purpose of faxation the taxable property in the state shall be classified as follows:

Class One. The annual net proceeds of all mines and mining claims. after deducting only the expenses specified and allowed by section 84.5403; also where the right to enter upon land. to explore or prospect. or dig for oil, gas, coal or mineral is reserved in land or received by mesne ennveyance (exclusive of leasehold interesis), devise or silccession by any Ixrson or corporation, the surface title to which hals passed to or remains III another, the state department of revenue shall determine the value 
of the right to enter upon said tract of land for the purpose of digfing, exploring, or prospecting for gas, oil, coal or minerals, and the same shall be placed in this classification for the purpose of taxation.

Class Two. All agricultural and other tools, implements and machinery, gats and other engines and boters, threshing mactines and outfits used therewith, antomohiles, motor trucks and other power-driven cars, vehicles of all kinds except mobile hones, boats and all watercraft, harness, satddlery and robes and except as provided in Class Five (b) of this section, all poles, lines, transformers, transformer stations, meters, tools, improvenents, machinery and other property used and owned by all persons, firıns, corporations, and other organizations which are engaged in the business of furnishing telephone communications, exclusively to rural areas, or to rural areas and cities and towns provided that any such city or town has a population of eight hundred ( 800 ) persons or less; and provided further, that the average circuit miles for each station on the system is more than one and one-quarter (1 $1 / 4$ ) miles.

Class Three. Livestock, poultry and unprocessed products of both; stocks of merchandise of all sorts, together with furniture and fixtures used therewith, except mobile homes; and all office or hotel furniture and fixtures.

Class Four. (a) All land, town and city lots, with improvements, and all trailers affixed to land owned, leased, or under contract or purchase by the trailer owner, manufacturing and mining machinery, fixtures and supplies, except as otherwise provided by the constitution of .lontana, and except as such property may be included in Class Five, Class Sevein or Class Eight.

(b) Mobile homes without regard to the ownership of the land upon which they are situated, except those held by a distributor or dealer of mobile homes as part of his stock in trade, and except as such property may be included in Class Eight.

- Class Five. (a) All moneys and credits, secured or unsecured, including all state, county. school district and other municipal bonds, warrants and securities, without any deduction ol offset; provided, however, that the torms "numess and credits" as herein used shall not embrace the moneyed capital cinployed in the banking business by any banking corporation or individual in this state.

(b) All poles, lines, transformers, transformer stations, meters, tools, improvements, machinery and other property used and owned by co-operative rural electrical and co-operative rurai telephone associations organized under the laws of Montana except those within the incorporated limits of a city or town in which less than ninety-five per cent $195^{\circ \prime} \mathrm{c}$ of the electric consumers andior telephone users are served by a co-operative organization, and as to the property enumerated in this sub-section (b) within incorporated limits of a city or town in which less than ninetyfive per cent $(95 r)$ of the electric consmmers or users will be served by a co-operative organization, such property shall be put in Class Two.

(c) All unprocessed agricultural products either on the farm or in storage. irrespective of whether said products are owned by the elevator. 
w:trehouse or flour mill owner or company storing the same, or any other pxrson whomsocver, except all perishable fruits and vegetables in farm starilge and owned by the producer, and excepting livestock and poultry and the: unprocessed products of bath.

(d) The dwelling house, and the lot on which it is erected, owned and uccupied by any resident of the stite, who has been honorably discharfied from active service in any branch of the armed forces, who is rated one lumbled per cent $\left(100^{\circ}\right)$ disabled due to a service-connected disability hy the linited States veterans administration or its successors.

In the event of the veteran's death, the dwelling house, and the lot on which it is erected, so long as the widow remains unmarried and the owner and areupant of the property, shall remain within this classification.

(lisss Six. Property formerly included in this class is now classified by section 8.1-308, R.C.MI. 19.47.

Class Seven. (a) All new industrial property. New industrial property shall mean any new industrial plant, including land, buildings, inachinery and fixtures which, in the determination of the state department of revenue, is used by a new industry during the first three (3) vears of operation not having been assessed prior to July 1, 1961. within the state of Muntana. New industry shall mean any person, corporation, firm, partnership, association, or other group which establishes a new plant or plants in this state for the opcration of a new industrial endeavor, as distinguished from a mere expansion. reorganization. or merger of an existing industry or industries. Provided. however, that new industrial proplerty shall be limited to industries that manufacture, mill, mine, produce, process or fabricate materials, or do similar work in which capital and labor are employed and in which materials unserviceable in their nitural state are extracted, processed or made fit for use or are substantially altered or treated so as to create commercial products or materials; and in no event shall the term new industrial property be included to ne:all property used by retail or wholesale nerchants, commercial services of any type, agriculture, trades or professions. And provided further, that «.W industrial property shall not be included to inean property which is uied or culployed in aly industrial plant which has been in operation in this state for three (3) years or longer. Aly person, corporation, firm, pirenership. association or other group secking to qualify its property for inelumn in this class shall nuake application to the state departinent of r.-1.lue in such nlanner and form as may be required by said department.

ii. A cupital incestment in a recognized nonfussil form of energy ferleruthon, to the catcht protided under section st-it03.

Class: Eightht. (a) Any improvement on real property. trailers affixed tw land or mubile home belonging to any person who qualifies under any "min or more of the hereinater set forth categrories. valued at not inure thill seventeen thous:and five hundred dollars $1 \$ 17.500$ ) which is owned (rr under a contract for deed, and which is actually occupicd by:

(1) a widow sixty-two (62) years of ayce or older, whether with or without nuinor dependent children, who qualifies under the income linitations of $(f)$, or 
(2) a widower sixty-five (65) years of age or older, whetleer witls or without minor dependent children, who qualifies under the income limitations of (1), or

(3) a widow with minor or dependent children regardless of age, who qualifies under the income limitations of (4), or

(4) a recipient of retirement benefits whose income from all sources is not more than four thousand dollars $(\$ .4,000)$ for a single person and five thousand two hundred dollars $(\$ 5,200)$ for a married couple per annum. Provided, further, that one who applies for classification of property under this class must make an affidavit to the state department of revenue on a form as may be provided by the state departricnt of reventic supplied without cost to the applicant, as to his income, if applicable, as to his retirement benefits, if applicable, or, as to his marital status, if applicable, and to the fact that he or she actually occupies such improvements with right of the county welfare board to investigate the applicant. on the completion of the form, as to answers given on the form. Provided, further, that the value of said property shall not increase during the life of the recipient of retirement benefits or widow or widower covered under this class. For purposes of the affidavit required for classification of property under this class, it shall be sufficient if the applicant signs a statement swearing to or affirming the correctness of the information supplied, whether or not the statenent is signed before a per'son authorized to administer oaths, and mails the application and statement to the department of revenue. This signed statement shall be treated as a statement under oath or equivalent affirmation for purposes of section 94-7-203, R.C.M. 1947, relating to the criminal of fense of false swearing.

(b) Any capital investment in a building for an energy conservation purpose, to the extent procided under section $S 4-7 \neq 03$.

. Class Nine. All property not included in the eight (8) preceding classes."

Approved May 13, 1975. 
Sinate Bill No. 552-Sinators Gibson. Brown. Litnb, Walker, Close, Schofield, Bryan, Hilbrecht, Echols, Hcrr, Neal and Blakemore

CHAPTER : $: \cdots$

A.N ACT appropriating the sum of $\$ 370,000$ from the state general fund for the purpose of Jespning. constructing. insrecting. equipsing and furnishing a solar enerky research laburatory in Clark County. Nevada. is an additional facility of the desere recearch institute of the L'niversity of Nevada: specifying the pumers, dutics and requirements of the state public works board and the board of refents of the University of Nevada: and providing other matters properly relating thereto.

The People of the State of Nevada, represented in Senate and Assembly, do enact as follows:

SECTION 1. For the support of the state public works board in carrying out the design, construction, inspection, equipping and furnishing of a solar cnergy research laboratory in Clark County, Nevada. as a tiucility of the descrt resc:Irch institute of the University of Vevada, therc is hereby appropriated from the general fund in the state treasury the sum of $\$ 370,000$.

SF. 2. The state public works board is hereby charged with the duty of carrying out the provisions of this act rclating to design, construction, inspcction, equipping and furnishings provicicd for in this act.

SEC. 3. The board of regents of the L'niversity of Nevada and the state public works board shall cooperate in carrying out the provisions of this act. All plans and specifications for the whole or part of the design, construction, equipment and furnishings shall be afproved by the board of regents of the University of Nevada and each contract shall be approved by the attorney gencrai before any such contruet mily be let.

SEC. 4. The state public works board shall employ competent architects, who in turn shall employ competcnt structural. mechanical and electrical enginecrs in preparing plans and specifications. The statc public works board shall advertise, in a newspaper of general circtilation in the Statc of Nevada. for separate saled bids for the construciion of the building hercin designated. Approved plans and specifications shall be on file at a place and time stated in such advertisement for the inspection of qualified contractors desiring to bid thiceon and for oiher interested persons. : The state public works boird, at its discretion, niay accept bids on either the wholc or on a part or parts of the design. construction, equipment or furnishings, and may let a contract for the while thereof, or a combination contract for structural, nechanical and electrical construction if savings will result thercby. to the lowest qualiticd bidder thereon: but any bids may be rejected for any good reason.

SEC. 5. This act shall become cffective upon passage and approval.

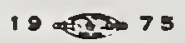




\section{CHAPTER 391.}

AN ACT PERMITTING A LOCAL OPTION TO ADOPT TAX EXEMPTIONS FOR REALTY EQUIPPED WITH SOLAR ENERGY HEATING OR COOLING SYSTENS.

Be it Enacted by the Senate and House of Representatives in General Court convened:

391: 1 Solar Energy Systems Exemption. Amend RSA 72 by inserting after section 60 the following new subdivision:

\section{Solar Energy Systems Exemption}

72:61 Definition of Solar Energy Systems. In this subdivision "solar energy heating or cooling system" means a system which utilizes solar energy to heat or cool the interior of a building or to heat water for use in a building and which includes one or more collectors and a storage container.

72:62 Property Tax Exemption. Each city and town may adopt under RSA 72: 63 an exemption from the property tax for persons orning real property which is equipped with a solar energy heating or cooling system.

\section{2: 63 Procedure for Adoption.}

I. A town desiring to adopt the provisions of RSA 72:62 may have the question placed on the warrant for a town meeting at which town officers are elected in the mamner provided in RSA 39: 3 . Such question shall be presented for voter approral in the following manner:

(a) For a town which has an oflicial ballot for the election of town officers, the officer who prepares the ballot shall place the question on such oflicial ballot as it appears in subparagraph (c).

(b) For a town which does not have an ofticial ballot for the election of town officers, the clerk shall prepare a ballot in the form as provided in subparagraph (c).

(c) The wording on the ballot of any referendum for the adoption of RSA 72: 6: shall be as follows: "Shall ire adopt the provisions of PSA 72: 62 for a property tax exemption on real property equipped with a solar energy heating or cooling system which exemption shall be in an amount ?" The amount of the exemption oi" the mamner of its determination shall be included in the witten application of the voters presented under RSA $39: 3$ and shall he inserted in the question on the referendum where the blank appears ainve.

(d) Upon the ballot containing the question shall be printed the word "Yes" with a square near it at the right hand of the question; and 
immediately below the worl "Yes" shall be printed the word "No" with a square neal it at the right hand of the question. 'The voter clesiring to vote upon the question shall malie a cross in the square of his choice. If no cross is male in a squale beside the question, the ballot shall not be counted on the question.

II. A city dlesiring to aldopt the provisions of RSA 72:62 may have the question placed on the oflicial ballot for any regular municipal election for the election of city ollicer's upon a vote of the city cuuncil or upon submission of a petition signed by five percent of the registered voters of the city to the city council. The vote of the city council and the petition of the voters shall include the amount of the exemption or the manner of its determination. The question sliall be placed on the otficial ballot by the city clerk with the wording and in the form provided for in paragraph I, (c) and shall include the amount of the exemption or the manner of its determination.

III. Upon approval of the question by a majority of those voting on the question, the provisions of PSA 7:2:62 shall be deemed to have been adopted and shall take effect on April first next following the referendum for the tax year beginning on such date.

IV. If after adoption of the provisions of RSA 72:62, any town or city desires to rescind its adoption, it may do so by referendum pursuant to paragraphs I or II, by changing in paragraph I, (c) the word "adopt" to read "rescind" in the question on the referendum; and provicled, further, that after the adoption of the provisions of RSA $72: 62$, any action to rescind shall not become effective until April first next following the action taken to rescind.

$V$. If after adoption of the provisions of RSA $72: 62$, any town or city desires to change its exemption, it may do so by referendum pursuant to paragraphs I or II, by inserting in the question on the referendum a different amount for the exemption or a different manner of its determination; and provided, further, that the change in the exemption shall not become effective until April first next following the action to change the exemption.

72: 64 Application for Exemption.

I. On or before April fifteenth of the year in which an exemption is claimed, a person qualified for the exemption under RSA $72: 62$ shall file an application for the exemption with the selectmen or assessols. The selectmen or assessors shall have an application form prepared, to be signed by the applicant under penalty of perjury, which shows that the appiicant is qualified for the exemption.

II. If any person otherwise qualified to receive such exemption shall satisfy the selectmen or assessor's that he was prevented by accident, mistake or misfortune from filing said application on or before $A$ pril fifteenth, said olticials may receive said application at a later date and grant an exemption thereunder, but no suen application shall be received or exemption granted after the local tax rate is approved.

III. If the selectmen or assessor's are satisfied that the applicant has wilfully made any filse statement in the application to obtain an exemption, they nily refuse to glant the exemption.

IV. Whenever the selectmen or assessor's refuse to grant an applicant an exemption to which lie mil he entitled under the provisions of RSA 72: 6.2, said applicant mity alpeal in witing within six months of receipt of the tax bill to the bond of taxation which nuay order an exemption or an abatement if the tax has been assessed.

\footnotetext{
:191:2 Effective Date. This act shall take effect sixty days after its i 1 : :.,

1: iruirel.Junn 16, 1975.]

[ [:1..etive date Aurust 15, 1975.]
} 


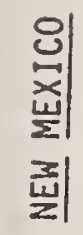

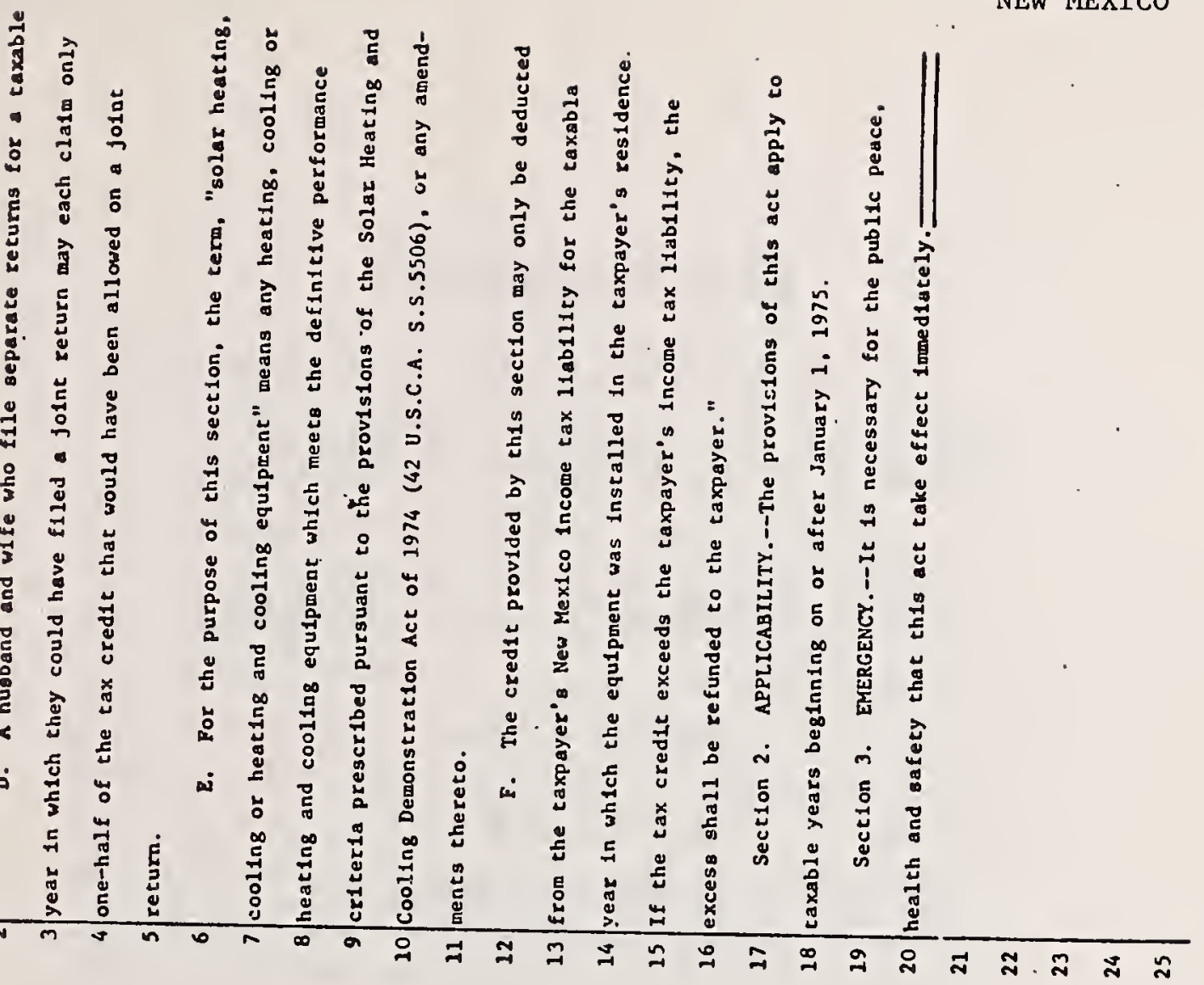

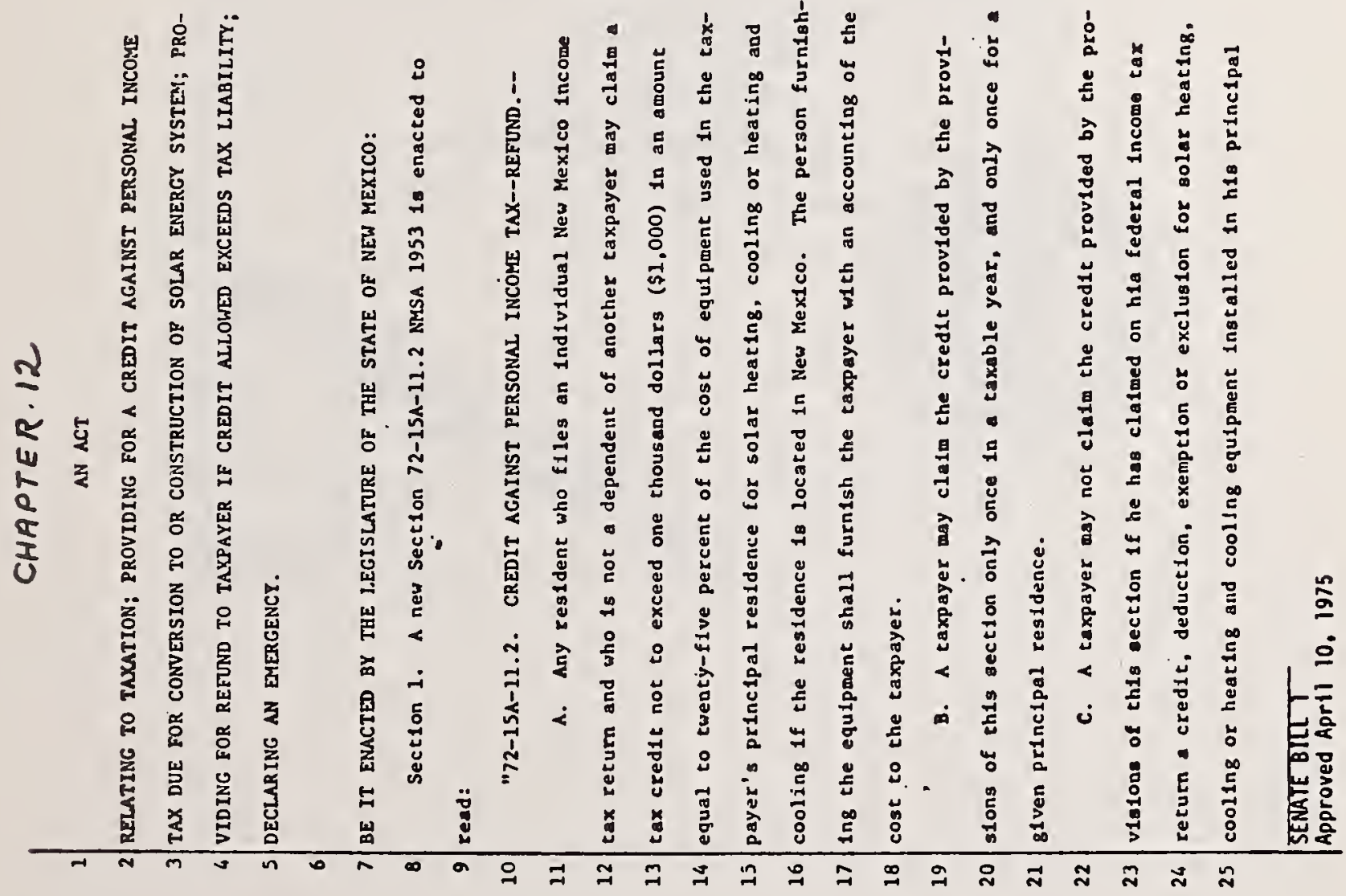




\section{The Legislature \\ of the \\ State of New Mexico}

32nd Legislature, 1st Session

LAWS 1975

$$
\text { CHAPTER } 83
$$

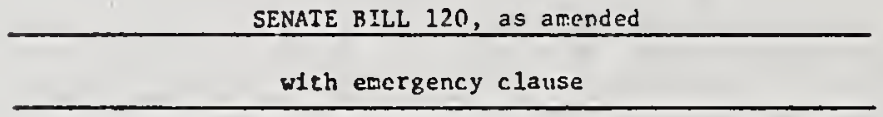

Introduced by

SENATOR JOHN B. IRICK

SENATOR ODIS L. ECHOIS, JR.

SELATOR THOMAS T. RUTHERFORD
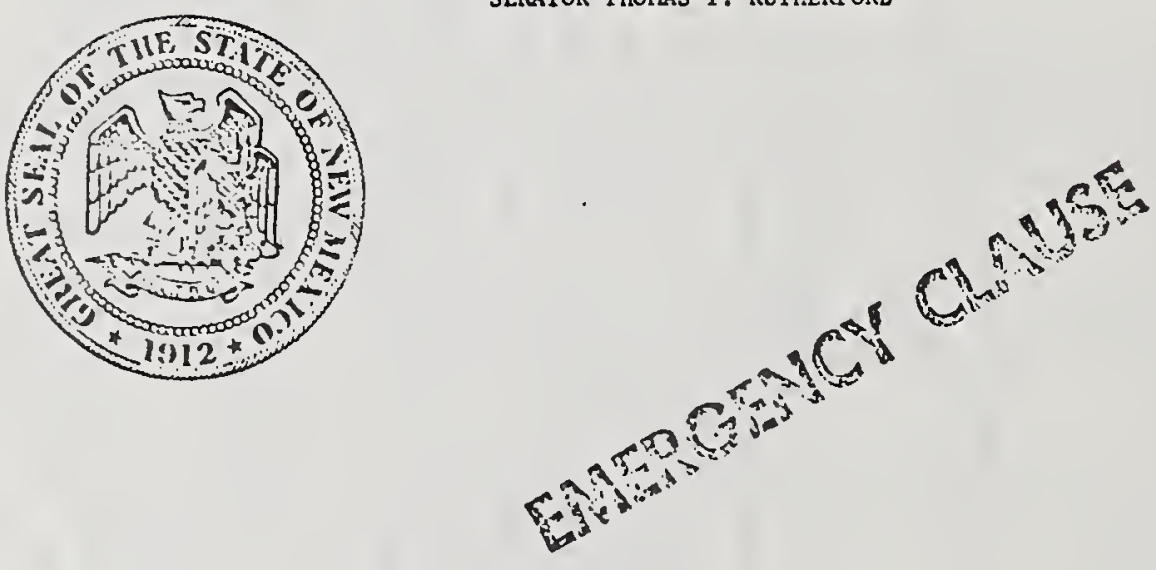


\section{CHAPTER 83}

RELATING IO SOLAR ENERGY RESOURCES; PROVIDING DUTIES; MAKING AN

Section 2. PURPOSE.--The purpose of the Solar Energy Development Act is to promote development and use of solar energy in New Mexico, by both industry and government for the benefit of New Mexico citizens and for the citizens of the United States. It is proposed to accomplish this purpose through active measuros to encourage the location within this state of the proposed national solar institute, rescarch to discover practical and feasible methods to harness solar energy to supplement exlsting but limited present sources of energy, and development of a vigorous and productive solar energy industrial ductive solar energy industrial complex;

C. actively seck and promote the state of New Mexico as the proper and idcal site, because of geographical location, climate,

SENATE BILL 120

Approved Aprt1 2, 1975 
research facllitics and plentiful supply of sclentific and technical

expertise, for the location of the proposed national solar institute;

D. develop necessary promotional material to be used in

the process of attracting new investment capital within the solar energy field;

E. cmploy sufficient staff to carry out the purpose of

the Solar Energy Development Act; and

F. cooperate with private firms and all agencles of the

state and federal government in furthering research and investment in solat energy use in New Mexico.

Section 4. APPROPRIATION.--The sum of thirty thousand dollars

$(\$ 30,000)$ is approprlated from the general fund to the department

of development for the purposes of carrying out the provisions of the

Solar Energy Development Act. Expenditure of this appropriation may

be made in the sixty-third and the sixty-fourth fiscal years. Bal-

ances unexpended or unencumbered at the end of the sixty-fourth fis-

cal year shall revert to the general fund.

Section 5. ERIERGENCY.-It is necessary for the public peace,

health and safety that this act take effect immediately. 


\title{
The Legislature
}

of the

\section{State of New Mexico}

32nd Legislature, lst Session

\author{
LAWS 1975 \\ CHAPTER 200
}

HOUSE BILL 395

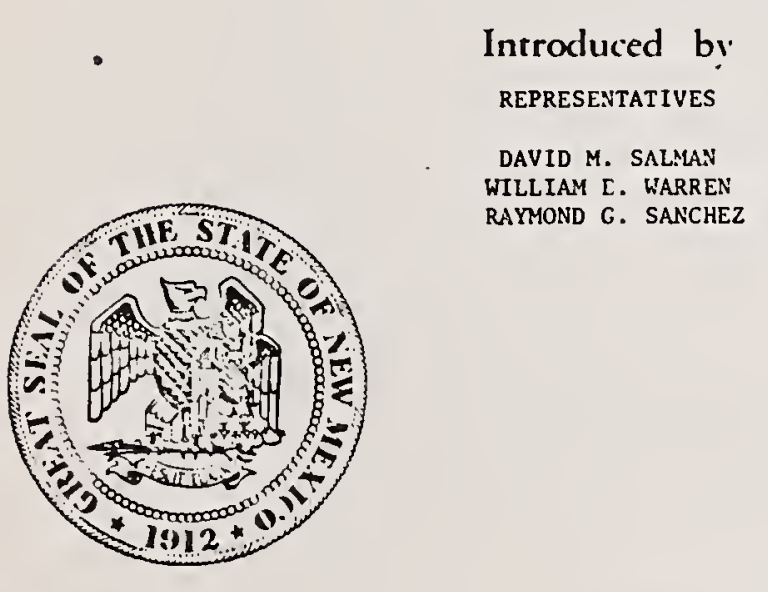


AN ACT

RELATIAG TO PUBLIC BUILDL:GS; PROVJ.DI:G THAT A FEASIBILITY STLDY OF

3 THE ENERGY SOURCE FOR IIEATING AND AIR CONDITIONING MUST BE MADE BEFORE. AVY CONTRACT IS EXECUTED FOR TIE CONSTRUCTION OR MUOR ALTERATION OF A STATE BUILDING.

BE IT ENACTED BY THL LEGISLATURE OF THE STATE OF RFW HEXICO:

Section 1. STATE BUILING CONTRACT--FEASIBILITY STUDY OF ENERGY SOURCES.--Before any contract is executed for the construction, major alteration or renovation of any state-owned building, the property control division of the department of finance and administration shall have a feasibility study made on the use of energy sources other than fossil fuels for the heating and air conditioning of the proposed building. A copy of the feasibility study shall remain on file with the property control division and shall be open to public inspection. 


\section{STATE OF NEW YORK \\ (1)}

S. 6716

A. 8620

1975-1976 Regular Sessions

\section{SENATE-ASSEMBLY}

June 9,1975

IN SENATE-Introdured by S'IIS. PISANI, BELLAMY, BLR-

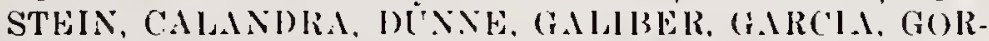

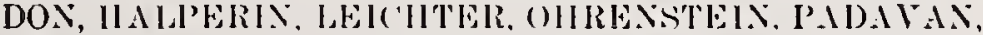
ROLISON, SCIIERIIERHORN, B. C. S.IITII, T.M RIELLO. TRLNZO, WINIlio)-read twiere and ordered printed, and when printed to he anmmitted to the ("ommittere on Corporations, Authoritie's and Public Ltilities

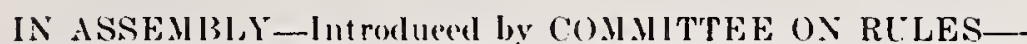

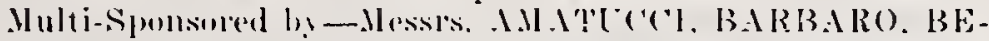

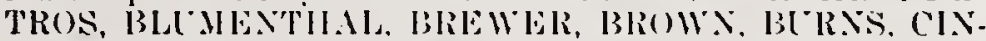

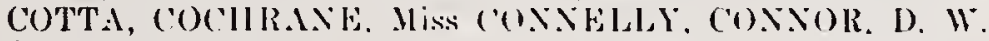

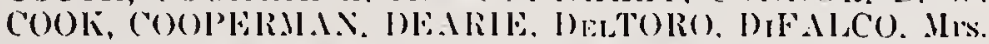

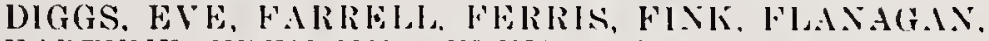

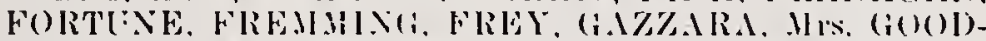

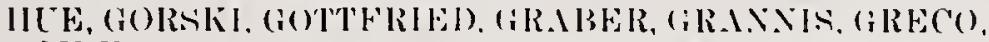

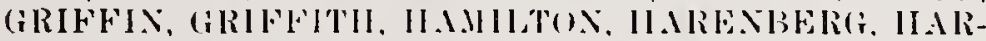

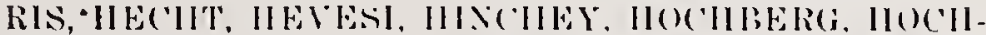

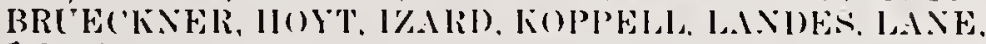

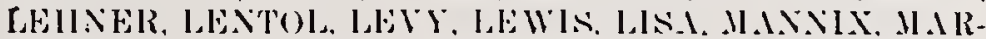

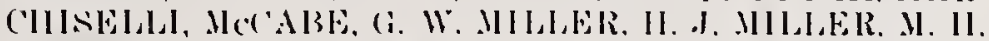

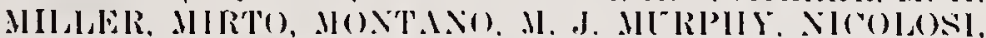

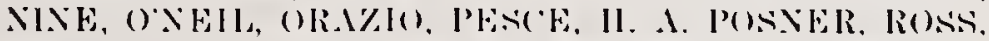

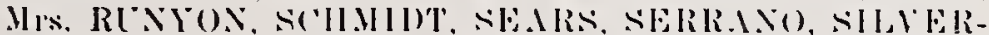

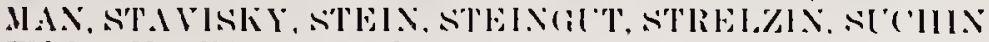

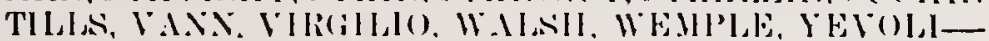

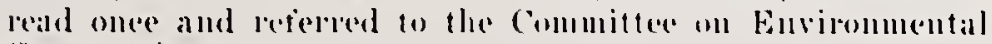
Conservation

Fixpanation - Matter in ilalics is new; matter in brackets $\mathbb{I}$ is old law to be omilted. 


\section{AN ACT}

to amend the public authorities law and the public service law, in relation to reconstituting the New York state atomic and space development authority as the New York state energy research and development authority, enacting the New York state safe energy act of nineteen hundred seventy-five and repealing certain

provisions of the public authorities law relating thereto

The People of the Stale of New York, represented in St nate and Assembly, do enact as follow's:

Section 1. Short title. This act nay be cited as the "New York state sufe energy act of $197.5 "$.

§ 2. The public authorities law is hereby aniended by alding thereto a new section, to be section eightecon humded fifty-a, to read as follow's:

\$ 1850-a. Legislative declaration. It is hercby derlared that the need for obtaining and maintaining an adequate and continuous supply of safe, dependable and economical pou'er and cncrgy is a matter of concern to the people of the statc; that the hi!h social environmental, health and economic costs of present fossil fuel energy make it imperative that such source bo used henceforth but sparingly in the state of New York; that the high social, curiroumental, halih and economic cost of nuclear fission ensrgy mates it imperative that such source not be used henceforth beyond cxisting facilities unless the legislature of the state of leu York specifically determincs by statute for cach application to the siting buard for a nuclear fission facility. for the three years suceceding the effective date of this act. that construction of ach propessed facility will be necessor!l to mect a compelling nest; and in plare therrof. alundaut and entironmentally aceepteble rnergy someres such as soler. Wind, solid uaste. and geothermal and bieconeression should be derelopud and utilized. The objectives of the pelicy capresserel in this ast ane the derelopment and utilization of sufe. de penduble, rencuruble and counomir ensig!y

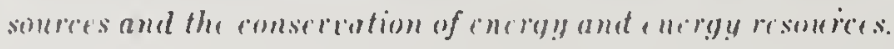




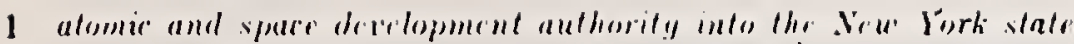

2 entry!g researh and ilenelopment anthority. While mainlaining its

3 gressut commitments to its boulholders, the authority shall direct its

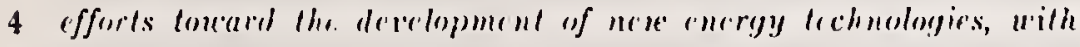

5 special cmphasis on renculable onerg!y soueres, and energy comseria-

6 tion technologies.

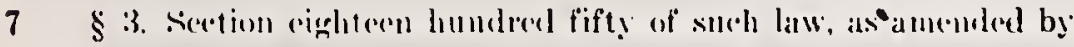

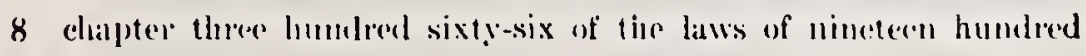

9 sixty-four. is hereby amemeled to read as follows:

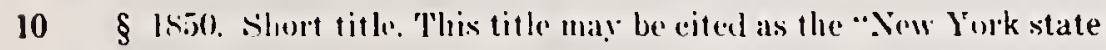

11 [atomic and spare devolopment] energ!y research and de celopment 12 authority act."

$\S$ 4. Sublivisions one and two of sertion righteen hondred

14 fifty-ene of such hal subdivision one as added by ehapter two

15 hunded ten of the laws of nineteen hondred sixty-two, subdivision

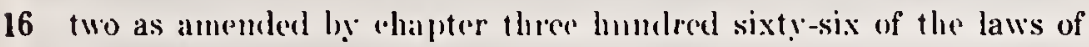

17 nineteen humbred sixty-four, are hereby amended to read,

18 respectively as follows:

1. "[.lomile] Iucleur fission energy" shall mein all forms of

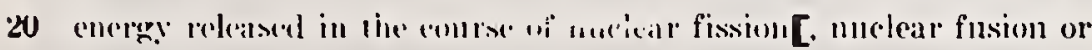
21 other nucleatl transformation]

2. "Authority" shall mean thu . New York state [atomice and spater] energy research and kevelopment anthority eontinued pursulant to seetion one thousand eight humberl fitty-two of this title. fity-one of such law, are hereby repealed and sublivisions nime, ten

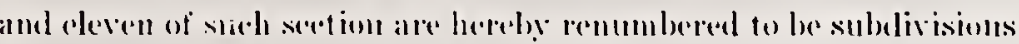

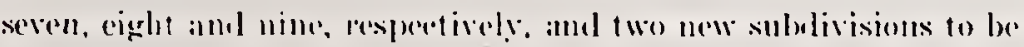

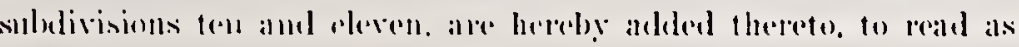
follows:

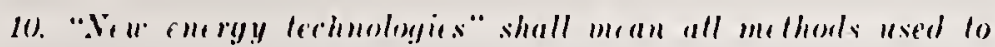

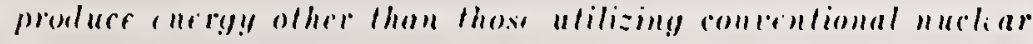
fision and fensil fuels.

11. "Finler construction" shall mern an!y project that shall hate

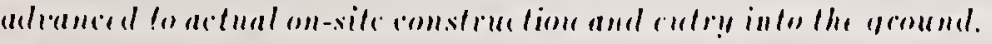

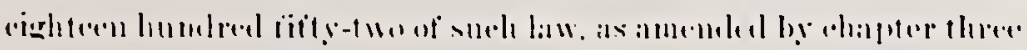




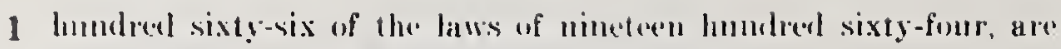

2 herehy amentenl to irad, resperetively, as follows:

3 New lork statc [atomio and sparer energy research and deredop-

4 Inent anthority. 1. The anthority herretufore known and designate! as

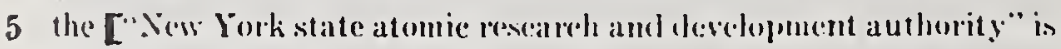

6 hereby (ontinned and shall hereater be knww and designated as

7 the " New York state atomice and spawe develupment anthority" is

8 hercby continued and shall hreafter be known and designated as the

9 : Vew York state energy research and development authority.

10 Reference in any provision of law, grenceal, sperial or lucal, or in any

11 rule, regulation or public denement to the New Yorth state atomic

12 researeh and development authority shall bo deremed to be and

13 construct as a reference to the anthority contimed by this section.

14 The authority shall be a borly corporate and politie, comstituting a

15 public benefit corporation. Its membership shall consist of [five]

16 eleven persons; three of which shall serve er-officio. The persons

17 serving as members of the New York state atomic and space [researeh

18 and] development authority on the effective date of this act shall [ue

19 the initial] serve as alditional mombers of the anthority for the

20 duration of the ir terms. [Adhlitional initial monubers to complete the

21 initial mentership of the anthority shall be appointed by the

22 gorernor, by and with the advice and consent of the senate.]

232 . The intial members of the authority shall serve for terms

24 ending Iprit first, nincteen hundred sixty-six, nineteen hundreci

25 sixty-seven. nineteen humdped șixty-eight, ninetern hundred six-

26 ty-thine and nineteen lumded seventy. respectively. In the case of

27 the person then serving as a nember and ehairnan of the New York

28 state: atomic research and development anthority on the effective

29 date of this act. such person shall rentinus to serve as a member for

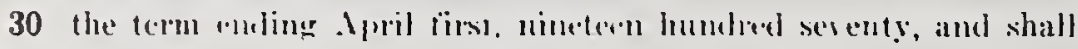

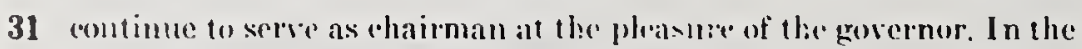

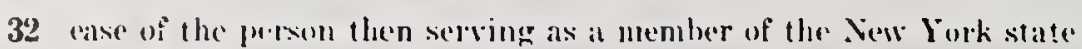

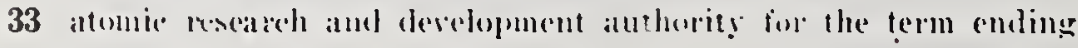

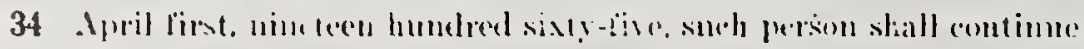

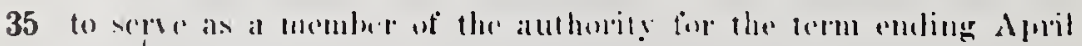

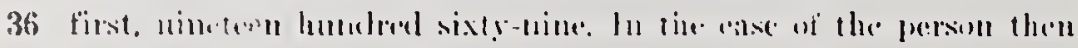

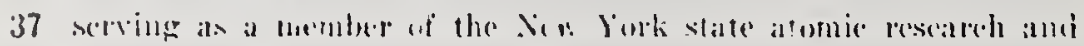

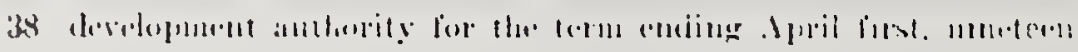


S. $(6716-1,86020$

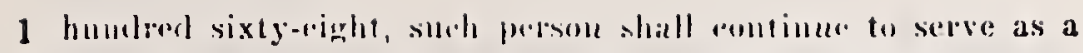

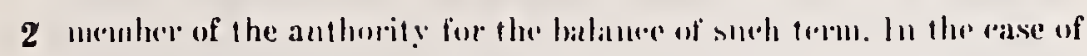

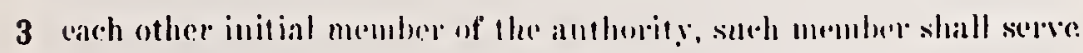

4 for the tern, not otherwise filled pmstant to the provisions of this

5 sublivision lwo. as may bo desiguated hy the gorernol in the

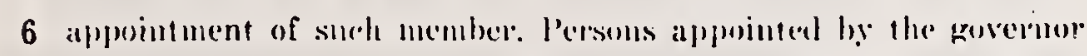

7 for full terms as suceessons to the intal memebers shall serve for

8 terms of six yeals cach commencing as of Amil firs] The mem-

9 bership of the authority shall comsist of the commissioner of the

10 department of entirmmental conswation, the ehairpersoni of the

11 public service commission, the chairperson of the power authority of

12 the slate of Ncu Jork, all of whom shall serve ex-officio: and eight

13 members appointed by the youernor by and with the advice and

14 consent of the senate; ome of whom, shall be an engineer or a

15 research scientist with a degrec in the physicul scicnees or engin-

16 ecring who has not becn employed in the muctear fission field for

17 three years preceding the appointment; one of whom shall be an

18 economist who shall not have recived more than one tenth of his

19 income from an clcetric utility for three years preceding the ap-

20 pointment; one of whom shall be a member of a not-for-profit

21 curiroumental group; one of uhom shall be a member of a not-

22 for-profit consumer group; and one of whom shall be an officer of an

23 electric utility. The inembers shall serve for terms of six years each.

24 The chairperson shall be designated by the gotemor from among the

25 members appointed by him, other than the ex-officio nembers, to

26 sertc as such at the pleasure of the govemor. In the event of a

27 vacaney (cecurring in the of fice of a member by death, resignation or

28 otherwise, the governur shall appoint a successor, by and with the

29 alvive and consellt of the senate, to serve for the balance of the

30 intexpired term.,

$31 \$ 7$. Section cightien hundred tifty-four of such law, as anended

32 by chapter two humdered ninety-fonle of the laws of nineteen laundred

33 sisty-erght, paragraph (e) of sublivision there thereof as adder by

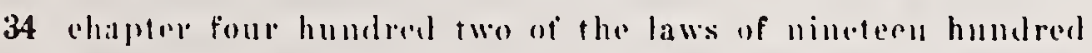

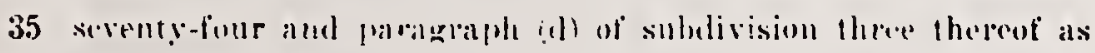

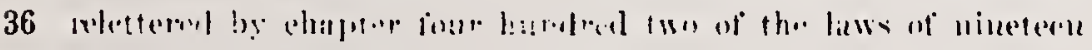

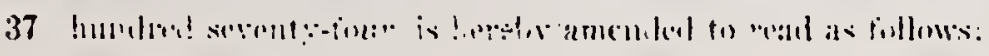

$\because$ 


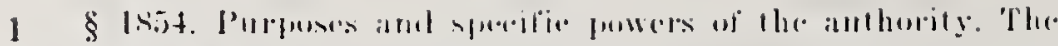

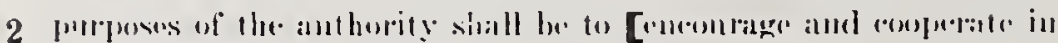

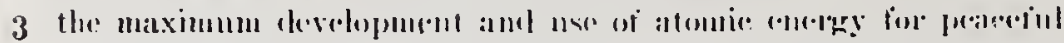
4 ant pushetive purposes within the state and in the aldive forth-

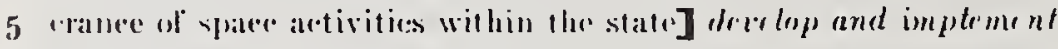
6 nele energy trihnotogiss, and to dive lop end incourage energy! 7 conservation technologies. In anying ont such purposes. the 8 authority shatl, with respeet to the aretivities speceified, have the 9 following powers:

1. Researeh, [and] development and demonstratiom. To comblnet.

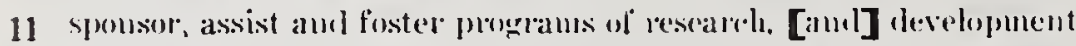
and demonstration in the nothenls of prouluction and nse of alomie enregy and programs relating to space activitics.] incholing the power to cstablish, areqnire. operate, develop and manage facilities thuefor:[.] in the methods of: (a) energy consertation. (b) production of pouer from neu energy technologics with emphasis on reneuable encrgy sources such as sotar, uind, bioconversion and sotid uaste, (c) storage of energy uith emphasis on inertial and battery storage, (d) conversion of facitities now utitizing nuclear fission energy and fossil fuet energy technologics, (e) transmission and distribution of poner, and ( $f$ ) methods of contersion of energy and improcements of efficieneirs of such conversion.

2. The provision of servires. To provicle services recpuired for the development and use of [atumice cuergy and services required for space aetivities] new eneryy production and conservation technologies by the imlustrial, commereial, medieal, scientific, educational and gorermmental organizations within the state, inchuling the powrer to establish, acefuire and elevelop facilities theretor not otherwise available within the state, and to operate and manage such faeilities.

3. Coppration with power companies. To contratet with or enter into joint mulertakings with an! fuwer anpang, of power anthority of the state of New lorte wr more than one of them, to

(a) Participate in the construtetion and oferation of ixperimental

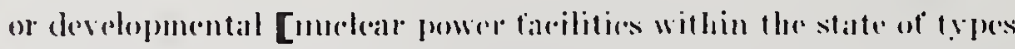

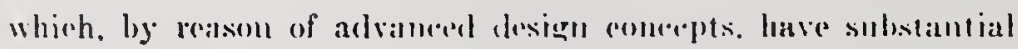

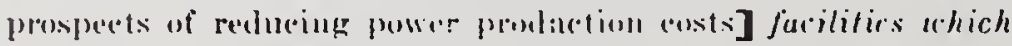

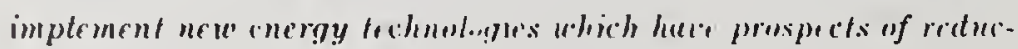




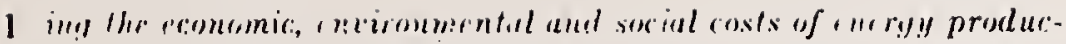

2 tion and utilization.

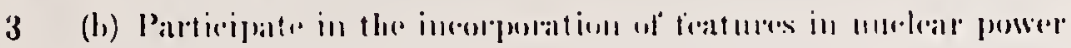

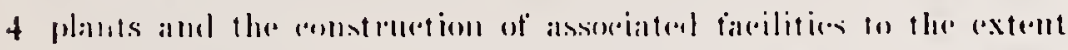

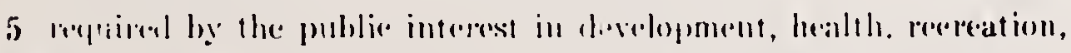

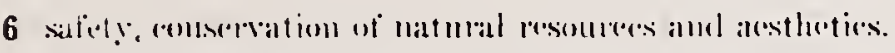

7 (c) Participate in the incorpmation of features in fossil fuel 8 power plants amel the construetion of associated farilities to the 9 extent recquired by the public interest in development, labalch,

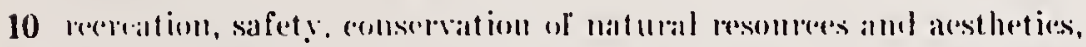
11 provided that the anthority shall not so alet with respect to any fossil

12 fuel power plant with resperet to which it had not talsen aftirmative

13 action towards the issuance of homls, as coutemplated by the

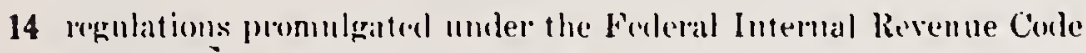
15 of 19.it, as ancmlerl. prior to July finst, nimeteen hundred 16 serenty-six.

17 (d) Develop, prepare, and fumish by sille or lease real property

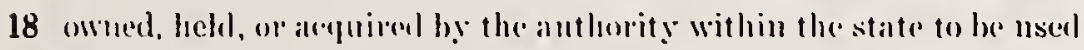
19. for the construetion and operation of [unclear puwer plants]

20 gencrating facilitirs based on new energy techologfios ansl related

21 farilitios, [Provided] provided that mo such contlatet or joint

22 rentme shall be (antered into which shall pelmit the althority to

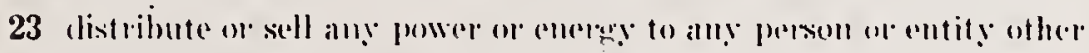

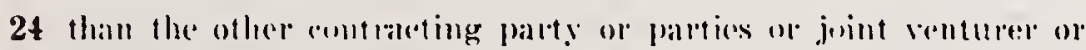

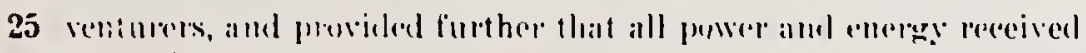

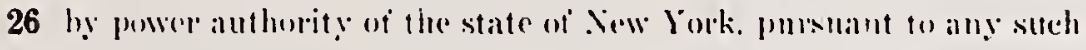

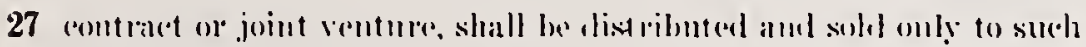

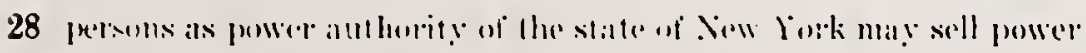

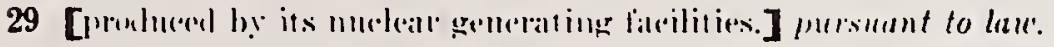

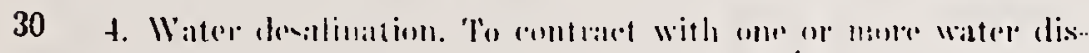

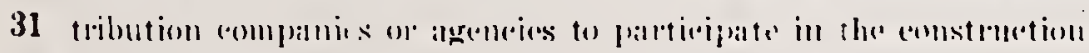

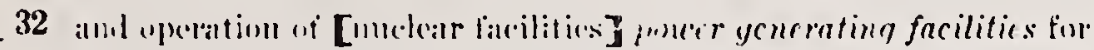

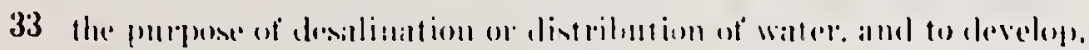

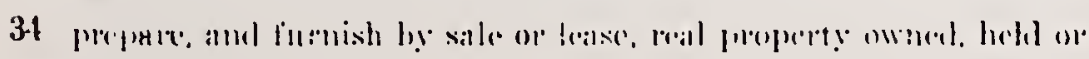

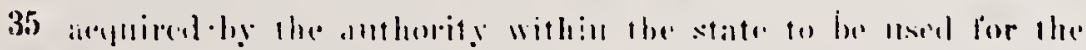

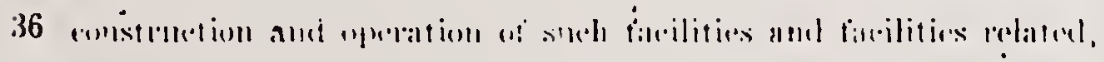

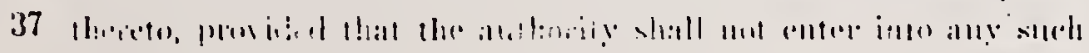

3. 


\section{S. (iT)ti--A. Nf:20}

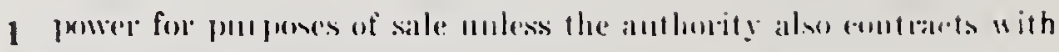

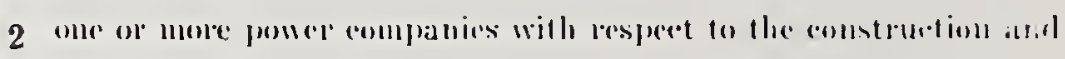

3 opetation of such findilig anel the distributien and use of such i joincr.

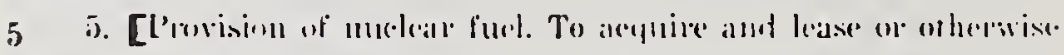

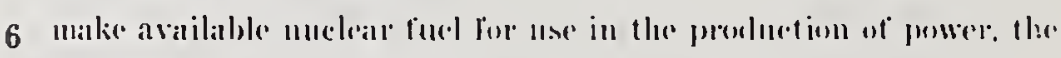
7 desalination of water or for ang other uscful purpuse within the 8 state.

9 6.] 'llac dissmination of information. To acromulate aml clis10 seminats information relating to the development and use of 11 [atomic enerẹ and relating to space activities] new energy tech12 nolugies and cucroy conservation techuologies. includiner the power 13 to contulet, sponsone, assist and foster studies and survers, and 14 publish the results thereot.

15 6. To continue such contractual agresments as may be in force at 16 the effecline date of this subdivision with regard to the West Ialley 17 nuclcur reprocessing facility and thr. Malta reseurch facility.

18 In exereising the powers granted by this title, the authority shall, 19 insofal as practioable. coupreate and art in conjunction with in-

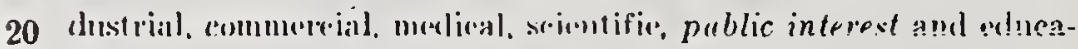

21 tional organizations within the state. and with agencies of the

22 freleral goremment, of the state ant its political subdivisions, of 23 other states, amel joint angeneies thereot.

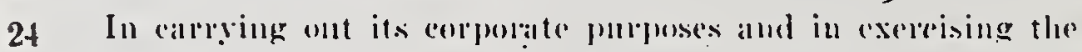
25 lywers gratuted by this title, the authority shall be regatsucd as |xerforming an essential governmental futletions.

$27 \$ s$ sublivision mo of sertion rightern lumbled tifty-nine of

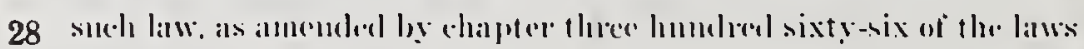
29 of nincterell humbed sixty-four, is hereby antended lu read ats 30 follows:

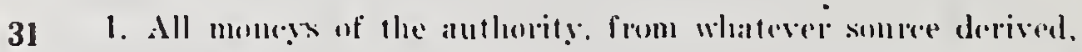

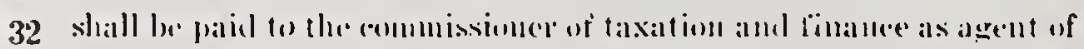

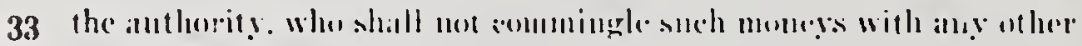

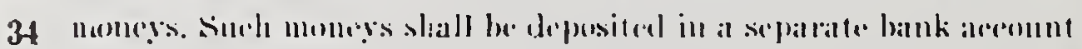

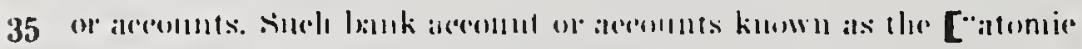

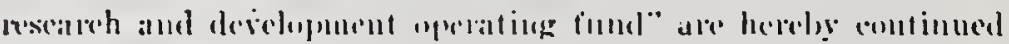

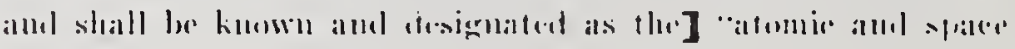

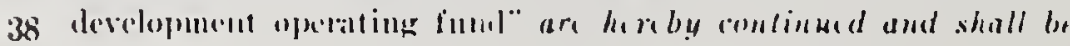


hou'n and hereb!y desigmeled as the rew roy rescurch and development operating fund. The moneys in steh thud may be expended for

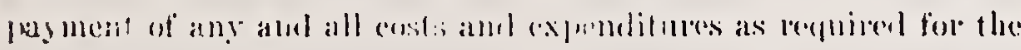

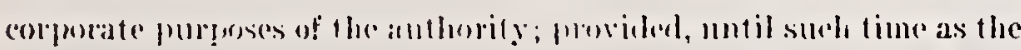

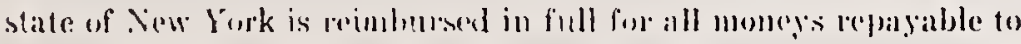

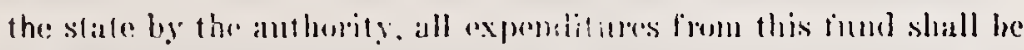
subject to the prion approwal of the direcesor of the butlenet of the

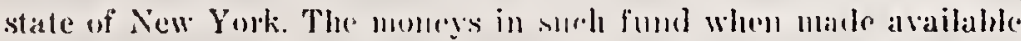
slaall be paid ont on cherels of the commissionery of taxation and

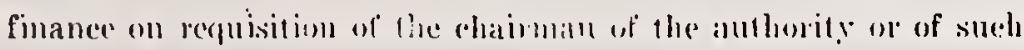

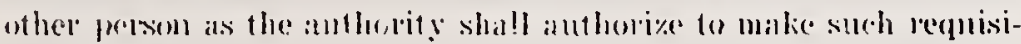

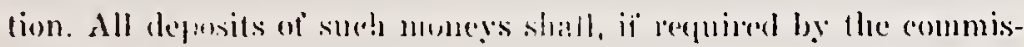
simer of taxation and finane of the antherity he sereused by

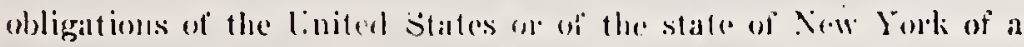
matket value erefual at all times to the amomot of the depersit and all

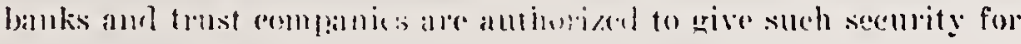
such deprosits.

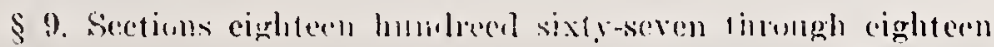

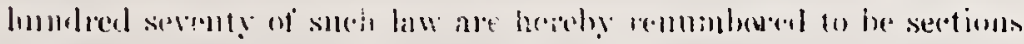

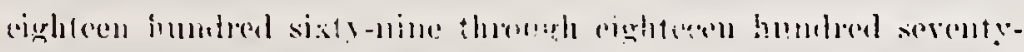

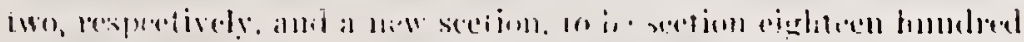

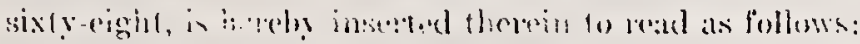

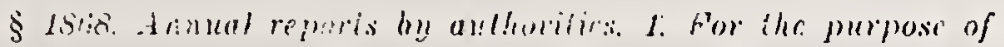
furnishing the siate with systematic informatimi regarding the

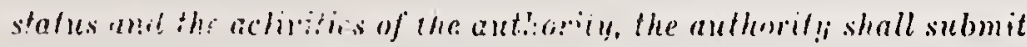

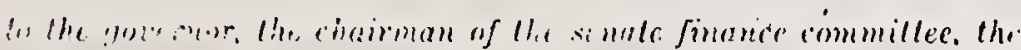

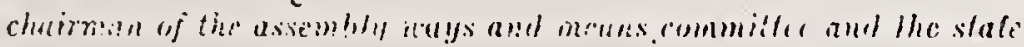

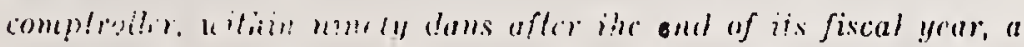

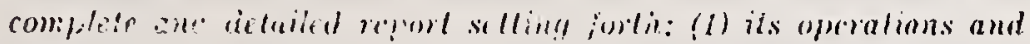

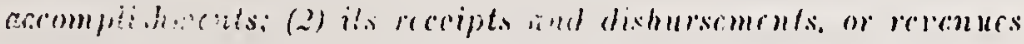

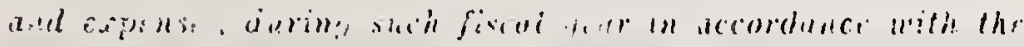

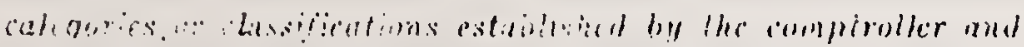

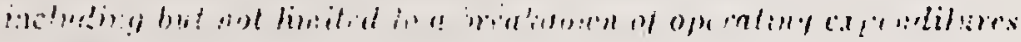

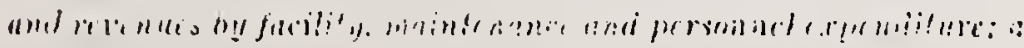

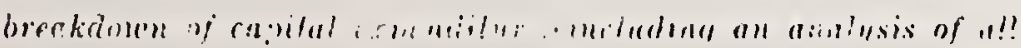

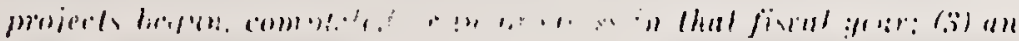

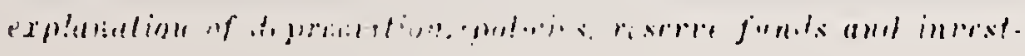




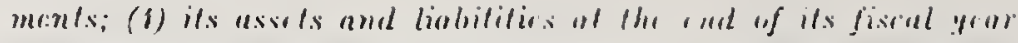

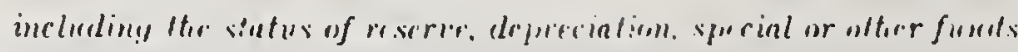

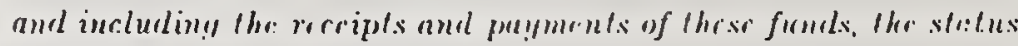

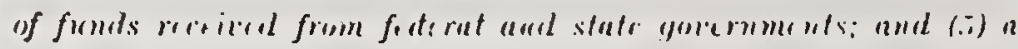

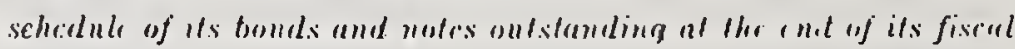
year, loggthir with a stafement of the amements redtamed and incurred during such fiscal your.

2. The authority. solong as it is not subject to the rivil service law, shall annually submit to the goremor, the chairman of the schate finance committer and the ctanirman of the as.sembly uays and means commille a report on its persomnil poticios and prac-

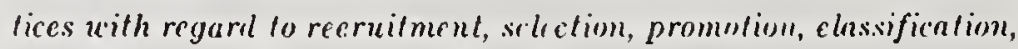
compensation. transfir, separation, imployee relations and services and equal opportunity programs.

3. The complroller shall be charged with sccing that the reports mandated in sublitision one are filed on lime and that they are sufficiently comprehensive. The comptroller shall report any deficiencics to the gotenor and to the leaders of the legistature.

4. The authority stall submit to the governor, the bullyet direetor, the state comptroller and the had of any pxecutive aycney performing the same or similar functions, chairperson.= of the scnate finaner committee and chairperson of the asis mbty uays and mcans committec, its proposed operafing bndget for the next ensning fiseal yrar and the opcrating budget for thr. present fiscat year.

5. The budget shall be submitted in a form spccificd by the budyet direfor. including. but not limitrd to, information on rates, coitracts, re'cenue and sources of revenue.

6. In the casc of the anthority owing monrys to the state, either through grants, first instaner uppropriations, ant olher subsidies, the buelget dirctor shall have the rigtet of approsinl as well as of revisu of the budget.

7. The comptroller stintl eneh year cerlif! to the butget director,

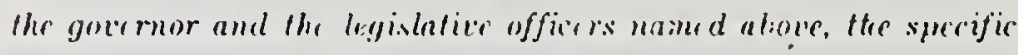

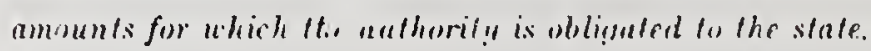

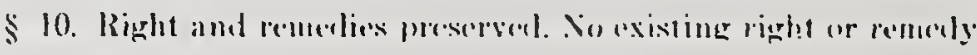

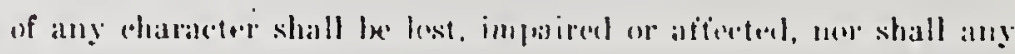

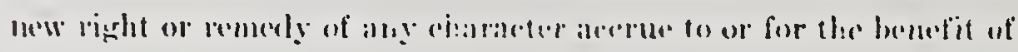
any person by reasom of the restexignation and continuation of the 
1

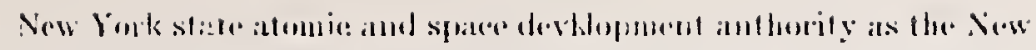

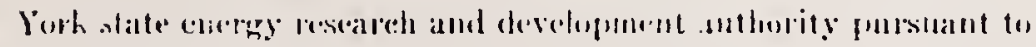
the provisions of this anet.

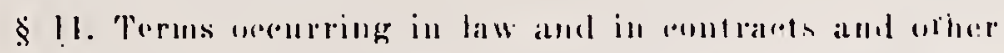

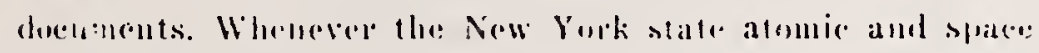

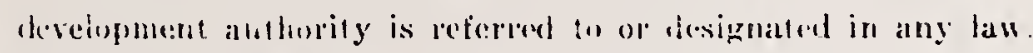

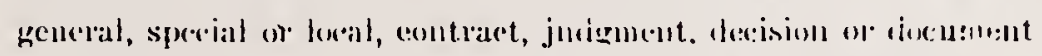

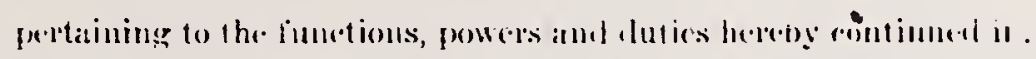

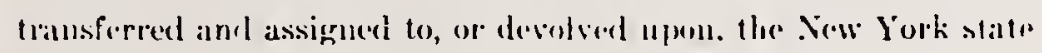
energy researeh and development anthority, such reference on designation shall be deemext to refer to and include Now Yolk state energy researoh and development authority, so fal as such law, eontuact, judgnent, decision or document pertinins to matters whieh are within its juristietion by reason of the redesignation, continuation, transfer, assignment and dewolution of tunctions, powers and duties made by this act.

\$ 12. Continuance of rules, regulations and acts. All rules, regulations and arts, decisions, deferminations and orders of the New York state atomic and space developunent anthority pertaining to the functions herein eont inued, tanasterend. assigned or derotred in fores or effective at the time or steh reslesignation, transere.

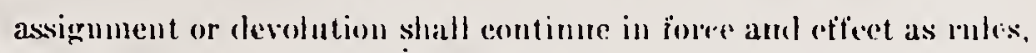
regulations, ants, derisions, determinations and orders of the New Fork state energy researelt and dovelopment authority, until noditied or abrogated.

§ 1:3. Contimuanes of rights and obligations. All rights, obligations, debts, liabilitic's. conditions, covennuts, pledgres, unde!:takings and (oummiturents of the New York state atomice and spane develop)ment authority. inchuding those contained in coureyances. laises. sub-le:ases, bunds. notes ol atrrements fo. foum. or with auy num-

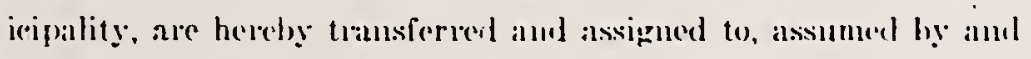

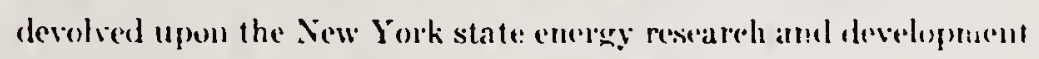

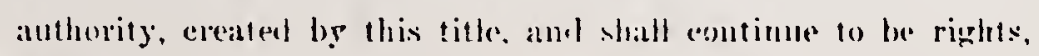

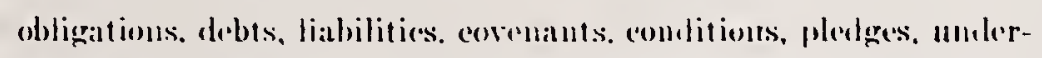

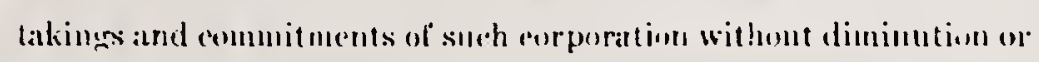
impaiment. 


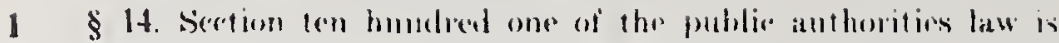

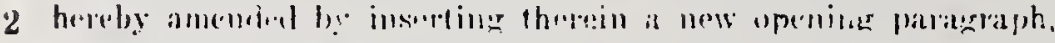

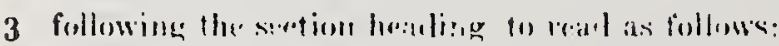

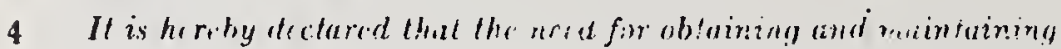

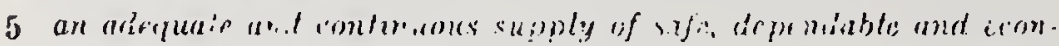

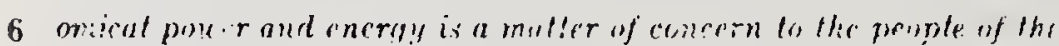

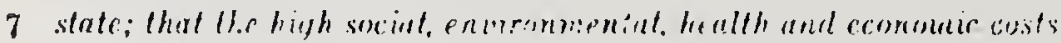
8 of present fossil furl encr!y inate it imprerative that such surct be 9 Wied henerforth but sporringly in the strte of Ney. Yorts: that the

10 high socinl, edirunmental, heuth and economic costs of nuelear 11 fis:ion eneryy nate it imperatiue that for the three years sueceediry 12 the effectire date of this a.t sweh sonere shati not be used heyrowi

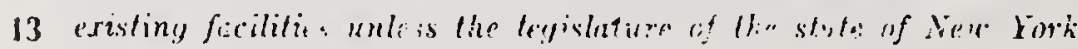

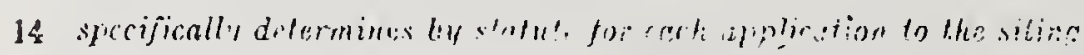

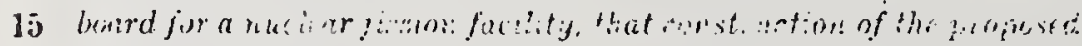

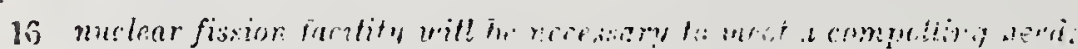

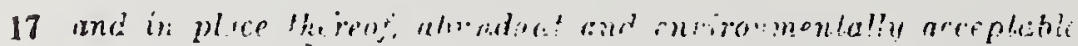

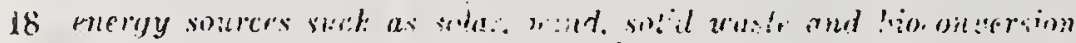
19 should toc d. vetried a

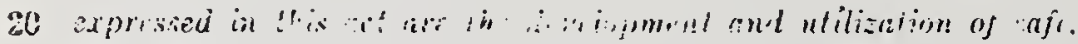

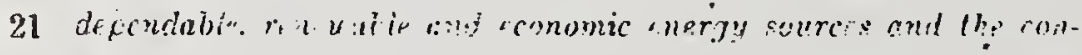

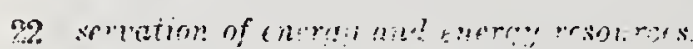

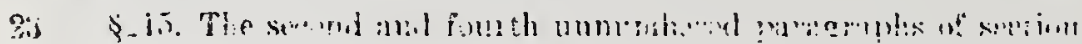

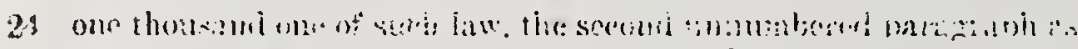

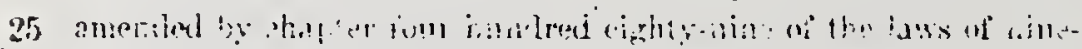

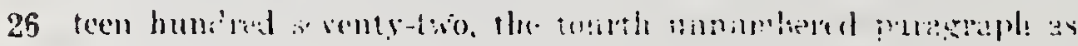

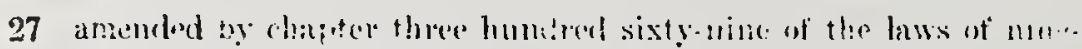

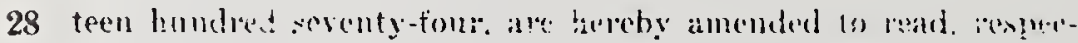
89 lively, as cillowis:

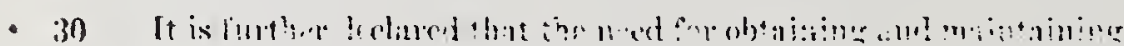

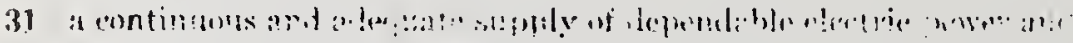

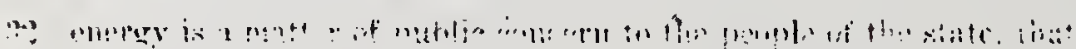

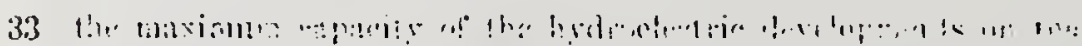

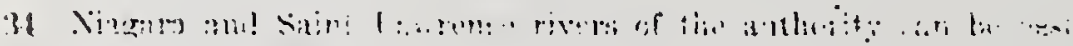

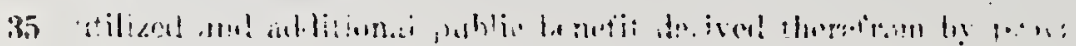

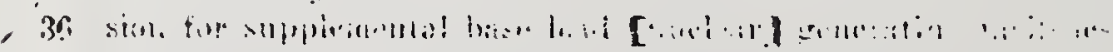

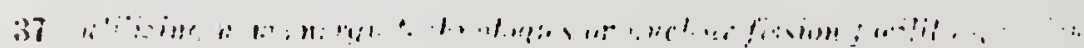

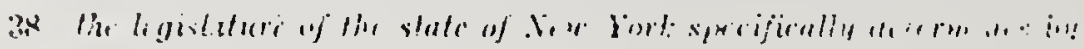




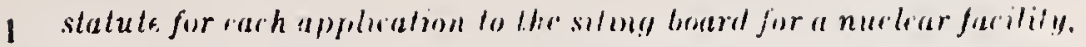

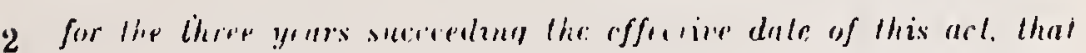

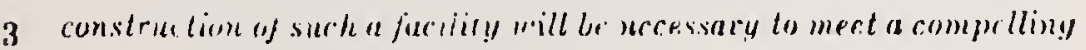

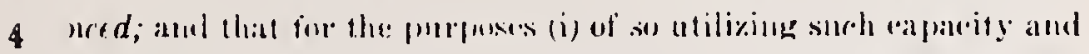

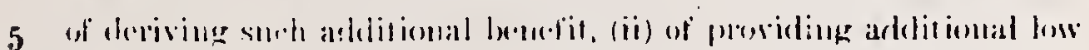

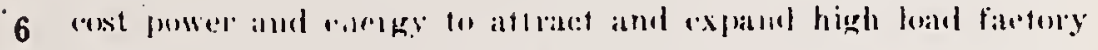

7 imblustry, riii, of confinuing an aterpunte: stupply of power and

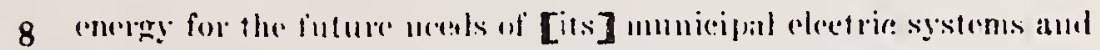

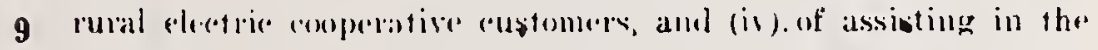

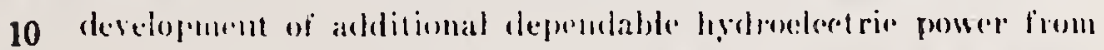

11 ofher watcres of the state and in the derelopment of advanced

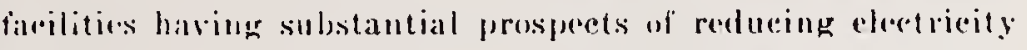

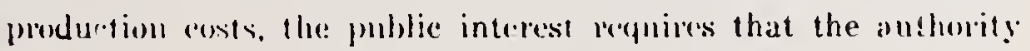
partiripate in the generation of supplemental electric power and

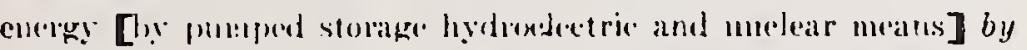
meani of these ocrgy siorage facitities. nuclear fission facilitics curreally in opcialion or under construction or which the Legislalure of the shate of Nou Vork sperifically detormines by slatute for ach appliation lo the siling bourd for a nuelear fusility, forl the thres yours succerding the effective date of this act, that

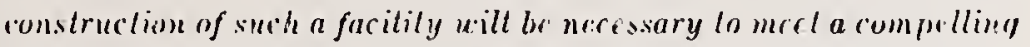

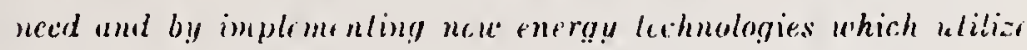
renerable theryy soures, utranced fossil fuet lechnologics and energy storage systems on the extent anthrorized in this title.

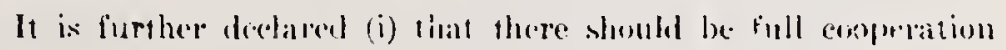

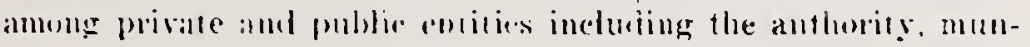

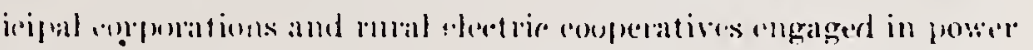

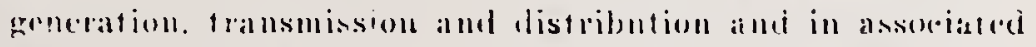

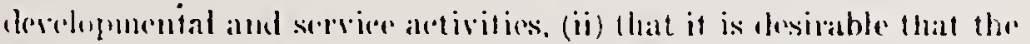
anthorit! and the ntilities wheh with the antherity anstifute the

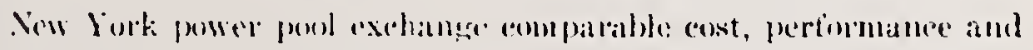

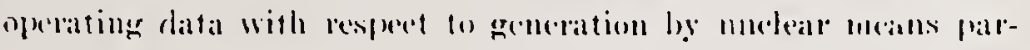

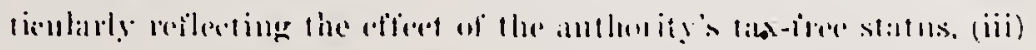

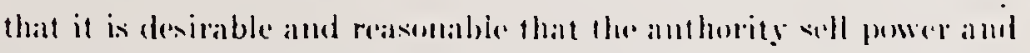

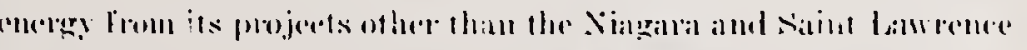

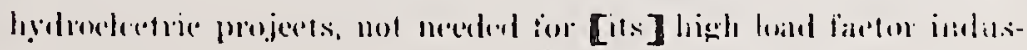

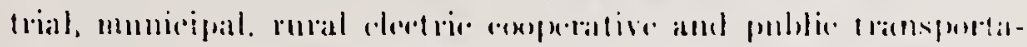




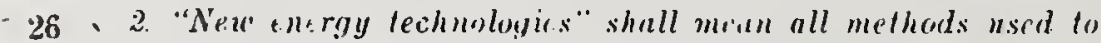

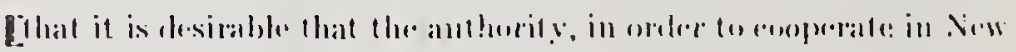

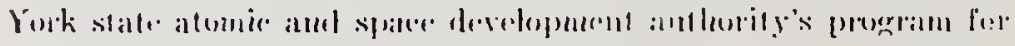

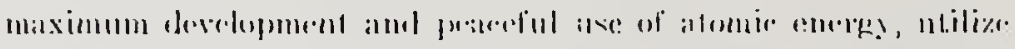

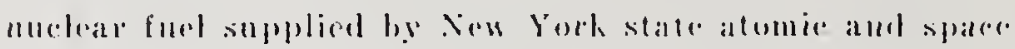
development anthority to the extent deremed advisable by the tristeres I that the authority shall give its fullest conperation to the cnergy research and deleloyment authorit! in advancin! and promoting the development and implemulation of new anergy Lchnolugics, and shall fulfitl its respunsibilitire for the devehument and maintenunce of a New York state base load to the groblest

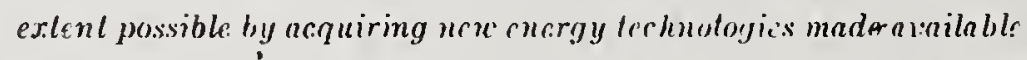
by the energy resenrth and deielopment athority and by constructing, developing, operating and maintaining gencrating facilities based "yom such new rncrgy techuologics. Upom rortification of the public service commission of the commercial feasibility of a new encray technolory, the outtority shait immodiatety ptan and construct a commercial instatlation of such trehnotogly. The euthority ma!y plen and construct such facilities in the absence of such certification.

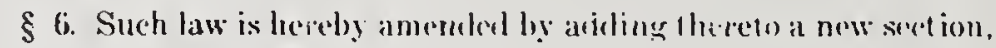
to be seetion une thousind ome-b, to read als follows:

\$ 1001-b. Difinilions.s. As used in this tittr:

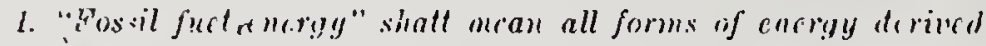
from ller? contrention al combistion of uil, gas or coal.

protuce energy otler than thes. utilizing contentional nucteur fission und fossil furls.

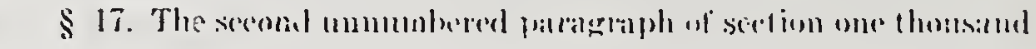

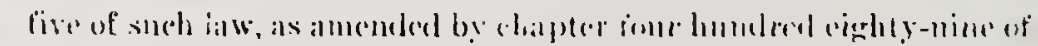

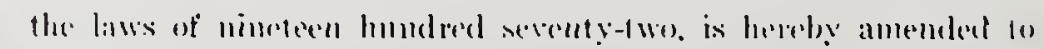
reviat ass follows:

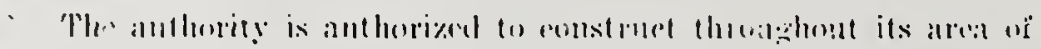

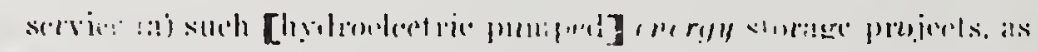

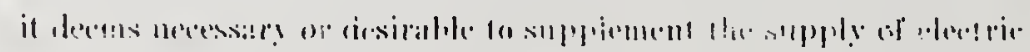

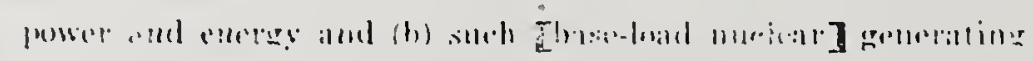

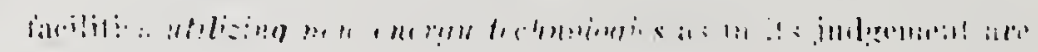

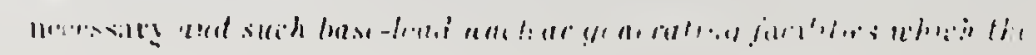

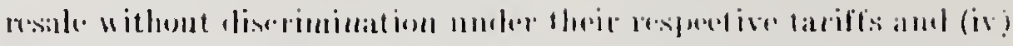




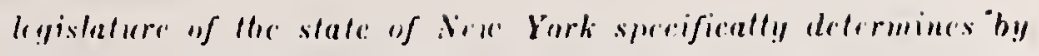

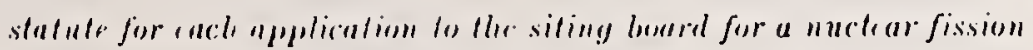

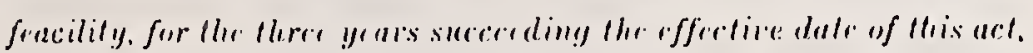

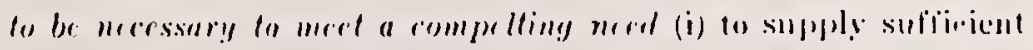

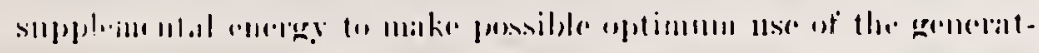

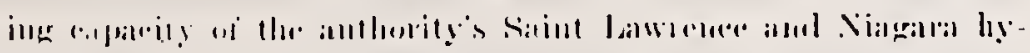

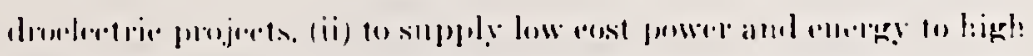

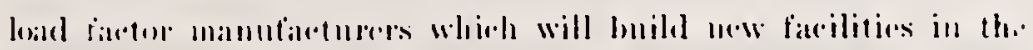

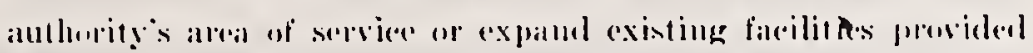

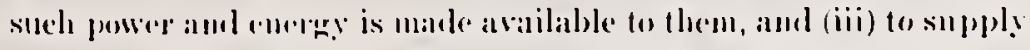

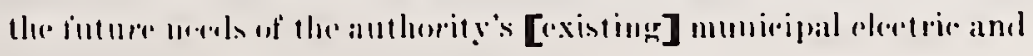

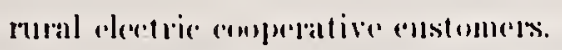

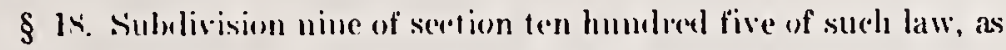
adken by rhapter two humbed ninety-fom of the laws of nineteen humbled sixty-righlt, is lereby annconded to read als follows:

9. To enoperate with and [, when the trustess deom it frasible aml advisable.] 11 onter into contuactual arrangements with Now York State [atomice and spalce] energy research and development authmity in comneretion with the planning. siting, development. construction, opmention and mainterance of [nuelear] generating farcilities of the anthority ulilizing new energy technologirs to the extent surh artion is consisteni with the purposes and powers granted by law to Siw lonk State [atomic and space] energy rescarch and developmunt authority.

$\$ 19$. Sublivision ten of section one thousand five of such law is herobs repealed and sululivisions cleven and twolve thereof are hereb!" renumbered an be suldivisions ten and eleven respertively. \$ 20). Sululivision tom-al of section eightern-a of the imblie service law is hereby repealed and a new sulmlivision. to le subdivision six. is herely ankled thereto to reatel as follows:

b. The costs of the Sirn York slale cuergy rescarch and de leloppment antharit! in cressis of that amount arailable from bonds. appropriatiats and grants in underlating rescarch, derelopment

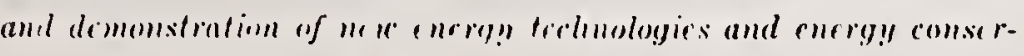

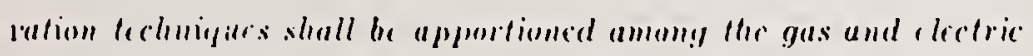
corfuralions as defined in section tero of this rhapter in accordance

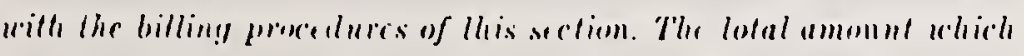

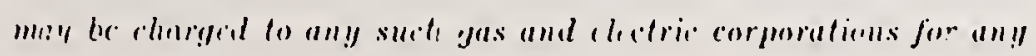




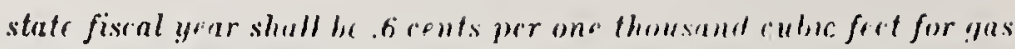
soll and .006 cents per hilharatt hener of electricity sold by such corporations in the ir intratiate ulility opuratome the lest peresdina

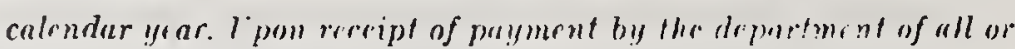
5 part of such apporoprintion. such funds shall he paid mere to the

(i eremplrnller es algent of sail awlhority for ucronent of the said 7 authority.

8 \$ 21. Such law is hereby amented by adling thereto a new 9 section, to be sertion one hundrenl forty-one-ia, to rearl an follows:

10 \$ 141-a. Lrgislative determination. 1. With respert only to the 11 construction of a unclcar fissinu facility. no r.rtifiralo of environ-

12 mental compatibilify and public nerd shall bo isward by the siting 13 board, for the three years suececding the rfforetier date of this act, 14 unlcss the legislature of the Statc of New Yorli shal! determine by 15 statutc for each application for a nuelear facility that such 16 construction will be necessery to mcet a compirlling need. Such 17 legislature determination shall be made within a ressinable period 18 and in no case later than 60 days after the eonvering of the next 19 Icgislative session following the receipt of the application by the. 20 Legishture for the proposid nuclear facilitu. certificate to construct a nuclear fission facility u.ithin ten days of its filing by uritten notification to the speaker of the assembly and the senate majority leader. The board shall make arailable to the legislature and any duly authorized committee thcre of all relevant material and the department of public service may submit recommendations regarding the proposed nuclear fission facility.

28 § 22. Section sixty-tive of such law is hereby amended by adding 29 thereto in new subdivision. 10 be subdivision one-a, to read as follows:

1-a. Notuithstanding the protision of any other law to the 31 contrary, in establishing the rate hase to be nsed by the electric 32 utility companies the commission shall disallone the rijrom after the 33 effective date of this act anu and all expenditures iclating to the 34 construction of any nuclear fission facility nut git under consinuc35 tion print to the effertive date of this sublinision unless the

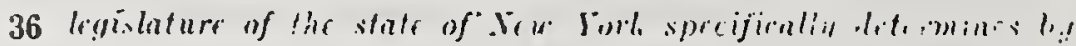

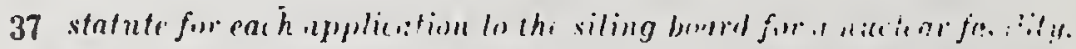
1 for the three yorars sucreseding the effective date of this act, that 2 construction of such nut lar fission facality uill be necessary to 3 meet a compclling need.

4 \$23. This art shall take effert imnediately. 


\section{GENERAL ASSEMBLY OF NORTH CAROLINA}

SESSION 1975

\section{RATIFIED BILL}

\section{CHAPTER 911}

HOOSE BILL 375

AN ACT TO APPROPRIATE FUNDS TO NORTH CAROLINA STATE UNIVERSITY FOR RESEARCH AND DEVELOPMENT OP A SOLAR HEATING AND COOLING SYSTEM RORKING MODEL POR NEW AND EXISTIRG HOMES, OFFICE BUILDINGS, SCHOOLS AND INDOSTRIAL PLANTS.

Whereas, there are no known fossil fuel deposits in North Carolina that can be commercially developed, but this state is a recognized leader in the derelopment and dissemination of knouledge; and

Thereas, solar energy is the world's most abundant renevable energy resource; and

Mhereas, the public velfare of this state would benefit. from the development of an inexpensive solar house heating and cooling system that can be applied to existing houses or new houses under construction and designed in such a manner, size and cost to encourage its use by home owners and builders; and

Whereas, wuch of the basic research into solar energy systems has been accomplished and disseminated and there is a vital need for demonstrated applications of solar energy systems on average North Carolina howes, office buildings, schools and indugtrial plants; and

Whereas, the ain of such research and devalopinnt should not be intwllectual inquiry as an end in itsell, but rather the videsprear introdurtion of nev systems for the utilization of 
solar nnorgy for homori, of fice buildingr. schools and industrial plant:i for hratind purpusu:s; Now, therefore.

The General Assiembly of North Carolina enacts:

Section 1. There is hereby appropriated from the reneral fund to the school of Engineering and the School of Desiqu of North Carolina state miversity the sum total of twenty thousand inllars $(\$ 20,000)$ for the fiscal year 1975-1976, and the sum of ten thousand dollars $(\$ 10,000)$ for the fiscal year. 19761977. For the purpose of research and development of a working solar house hroting and cooling system of a kind and size that can bn applied to existing houses, and new houses under construction, and to office buildings, schools and industrial plants; and such research and development is to be conducted in a manner consistent with the purposes set forth in the preamble to this act.

Sec. 2. North Cacolina State University is hereby athorized to spond a portion of the funds hertin appropriated to design. construct and display at the North Carolina state Pair a solar heating and cooling system model for the purpose of demonstrating and encouraging the use of solar energy for the beating and cooling of existing homes, new homes under construction, office buildings, schools and industrial plants in North Carolina.

Sec. 3. North Carolina State University is hereby authorized to apply for, obtain and spend any federal grants of tunds a valiable from the federal government for use in a maner consistent with the purposes herein designated.

Sec. 4. North Carolina state University is hereby 
athorized to apportion the funds herein appropriated, and any matching federal tunds obtained as authorized herein, among the schonl of Fnginrering and its departmentr., the school of Design and its departments, and any foint projects between those two schools, in any manner consistent with the purposes herein designated.

Sec. 5. All expenditures wade from the funds appropriated by this act and for the purposes herein designated shall be accounted for and reported according to the fiscal and financial system of the agencies to whom the appropriations are ade as herein set forth.

sec. 6. This act shall become effective upon ratification.

In the General Assembly read three times and ratified. this the $26^{\text {Th }}$ day of June, 1975.

JAMES B. HUNT, JR.

James B. Hunt, Jr.

President of the senate

JAMES C. GREEN, SR.

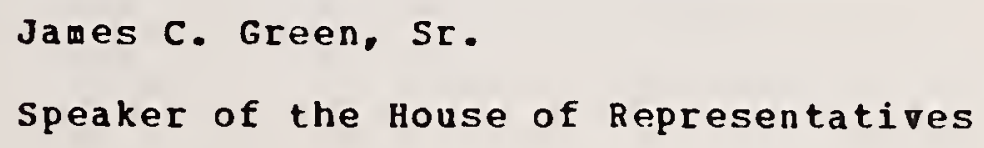


I:SeM

CIMITH:H :NM

TAXATION

\section{CHAPTER 508}

SENATE EILL NO. 2439

(Conlin, J. Schultz)

\section{SOLAR FNIRGY SYSTEM EXEMPTION}

AN AC' to create and enact a new subsection to section 57-02-08 of the North Dakota Century Code, relating to the exemption from property taxes of solar energy systems to heat or cool buildings and structures, and to provide for a time limitation.

BE IT ENACTED BY THE LEGISLATIVE ASSEMBLY OF THE STATE OF NORTH DAKOTA:

SECTION 1.) A new subsection to section 57-02-08 of the North Dakota Century Code is nereby created and enacted to read as follows:

Installations, machinery, and equipment of systems which utilize solar energy for the heating or cooling of new or existing buildings or structires, provided that if a bullding or structure has a conventional heating or cooiing system which is supplemented by a solar energy system, only the snlar energy portion of the total system shall be exempt. Proviced, however, that any exemptions granted by this sliosection shall be valid for a five-year perzod foilowing installation of any such system.

Approved April 8, 1975 


\section{AN ACT}

To amend sections $122.09,122.63$ to 122.73 , and 123.01 , to enact sections $122.671,122.74$ to 122.87, and 5709.30 to 5709.37 and to repeal section 122.08 of the Revised Code to create an Ohio energy and resource development agency to administer a comprehensive, coordinated program to meet energy needs throughout this state, authorize the agency to award grants and contracts for energy and resource experimental development demonstration facilities, authorize the agency to issue energy and resource development revenue bonds, direct the agency to give priority to assisting in the construction of a coal conversion plant, provide a 30-year personal property and franchise tax exemption for coal conversion facilities constructed prior to 1983, grant the governor energy emergency powers, and transfer to the agency assets and property of the Ohio development center and energy emergency commission, make an appropriation, and to declare an emergency.

Be it enacted by the General Assembly of the State of Ohio:

SEcrion 1. That sections $122.09,122.63,122.64,122.65$, $122.66,122.67,122.68,122.69,122.70,122.71,122.72,122.73$, and 
123.01 be amended and sections 122.671, 122.74, 122.75, 122.76, $122.77,122.78,122.79,122.80 .122 .81,122.82 .122 .83,122.81,122.85$, $122.86,122.87,5709.30,5709.31,5709.32,5709.33,5709.34,5709.35$, 5709.36 , and 5709.37 of the Revised Code be enacted to read as follows:

Sec. 122.09. The director of the department of economic and community development, with the approval of the governor, may appoint technical and advisoly BOARDS as he considers appropriate to assist him in carrying out the functions and duties of the department. The be limited to

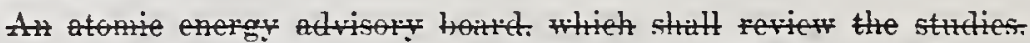

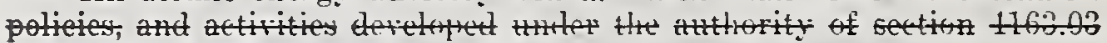
of the Periset Gote or other

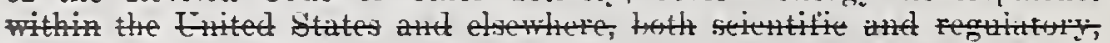

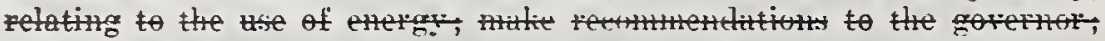

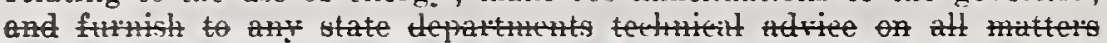

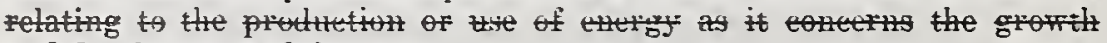
and of the stite.

The members of the advisory boards shall serve without compensation, but shall be reimbursed for the necessary expense incurred in the performance of their official duties.

Sec. 122.63. As used in sections 122.63 to 129.73122 .83 of of the Revised Code:

(A) "Gorernmental agency" means the United States government or a department, division, or any agency or authority thereof or a department, agency, division or any unit of a state government, a municipal corporation, countv, township ${ }^{\prime}$. BOARD OF EDLCATION. or other political subdivision or any other body corporate and politic. THE UNITED STATES OR ANY AGENCY OR INSTRLMENTALITY THEREOF, OR ANY AGENCY, COMMISSION, OR AUTHORITY ESTABLISHED PURSUANT TO AN INTERSTATE COMPACT OR AGREEMENT.

(B) "ENERGY AND RESOURCE DEVELOPMENT FACILITY" MEANS ANY ENERGY OR RESOURCE DEVELOPMENT FACILITY, INCLUDING UNDIVIDED OR OTHER INTERESTS THEREIN, ACQLIRED OR TO BE ACQUIRED. OR CONSTRLCTED OR TO BE (ONSTRLCTED BY THE OHIO ENERGY AND RESOURCE DEVELOPMENT AGENCY UNDER SECTIONS 122.63 TO 122.83 OF 'THE REVISED CODE, OR ACQUIRFD OR TO BE ACQUIRED, OR CONSTRUCTED OR TO BE CONSTRUCTED BY A GOYERNIIENTAL AGENCY OR PERSON WITH ALL OR A PART OF THE COST THEREOF EEING PAID FROM A LOAN OR GR.ANT FROMT THE AGENCY L'TIER SUCH SECTIONS, INCLUDING ALL BUILDINGS AND FACILITIES THAT THE AGENCY IETERMIINES NECESSARY FOR THE OPERATION OF THE FACILITY, TOGETHER WITH ALL 
PROPERTY, RIGHTS, FASEMFNTS, AND INTERESTS THAT MAY IBE IREQUIREI) FOR THE (IPELIATION OF THE FACILITY, WHICH FACILITIES MAY INCLUDE:

(1) ANY PLILDING, TESTING FACILITY, TESTING DEVICE, OR SLPPORT FACI! !TIES WIIICH WOULD PROVIDE EXPERIMENTAL, DEMIOASTRIOY OR TESTING CAPABILITIES OR SERVICES NOT OTIIFRWISE AVAILABLE IN THIS STATE AND WHICH ARE NECESSARY FOR THE ACCOMPLISHIENT OF 'THL' PUII'OSES OF SECTIONS 122.63 TO 122.83 OF THE REVISED CODE:

(2) ANY METHOD, PROCESS, STRUCTURE, OR EQUTPMENT THAT IS LSED TO STORE COAL, OIL, NATURAL GAS, FUEL FOR NUCLEAR REACTORS, OR ANY OTHER FORM OF ENERGY;

(3) ANY METHOD, PROCESS, STRUCTURE, OR EQUIPMENT THAT IS LSED TO RECOVER CR CONVERT COAL, OIL, NATURAI, GAS. STEAM, OR OTHER FORMI OF ENERGY FROM PROPERTY LOCATED WITHIN THE STATE FOR THE PURPOSE OF SLPPLIING ENERGY FOR LTILIZATION;

(4) ANY METHOD, PROCESS, STRLCTURE, OR EQUIP. MENT THAT IS DESIGNED TO RESULT IN MORE EFFICIENT RECOVERY, CONIERSION, OR UTILIZATION OF ENERGY RESOURCES WITHIN THE STATE.

(C) "COST" AS APPLIED TO AN ENERGY AND RESOURCE DEVELOPIIENT FACILITY IIEANS THE COST OF ACQUISITION AND CONSTRUC'TION, THE COST OF ACQUISITION OF ALL LAND, RIGITS-OF-WAY, PROPERTY RIGHTS, EASEMENTS, FRANCHISE LIGHTS. AND INTERESTS REQUIRED FOR SLCH ACQUISITION AND CONSTRUCTION, THE COST OF DEAIOLISHING OR REMOYING ANY BUILDINGS OR STRUCTURES ON LAND SO ACQUIRED, INCLUDING THE COST OF ACQUIRIAG ANY LANDS TO WHICH SUCH BUILDINGS OR STRLCTLRES MIAY BE NIOVED. THE COST OF ACQUIRING OR CONSTRUCTING AND EQUIPPING A PRINCIPAL OFFICE AND SUPOFFICES OF THE AGENCY, THE COST OF DIVERTING HIGHWAYS. INTERCHANGE OF HIGHWAYS, ACCESS ROADS TO PRIVATE PIOPERTY, INCLUDING THE COST OF LAND OR EASEMENTS FOR SLCH ACCESS ROADS, THE COST OF PIBIIC UTILITY AND COMIION CARRIER RELOCATION OR DLPLICATION, THE COST OF ALL MACHINERY, FURNISHINGS, AND EQLIPIIENT, FINANCING CHARGES, INTEREST PRIOR TO AND DIRING CONSTRUCTION AND FOR NO MORE THAN EIGHTEEN MONTHS AFTER COMIPLETION OF CONSTRLCTION. ENGINEERING, EXPENSES OF RESEARCH AND DEVELOPUENT WITH RESPECT TO THE FACILITY, LEGAL EXPENSES. PLANS, SPECIFICATIONS, SLRTEYS, STUDIES, ESTIMIATES OF COST AND REVENUES, WOR IING CAPITAL. OTHER EXPENSES NECESSARY OR INCIDENT TO DETERHUNING THE FEASIBILITY 
OR PRACTICARILITY OF ACQUIRING OR CONSTRUCTING SUCH FAC;IITY, AUMINISTRATIVE FXPENSE, AND SUCII OTHER FXI'ESF AS MAY [B' NECIESSARY OI INCITENT TO THE ACQUISITIONOR:ONSTILCTION OF TIHE FACILITY, THE FINANCING OF SUCH AC'RUISITION OR CONSTRUCTION, INCLUDING THE AIOUNT IUTIIOIZED IN TIIE RESOLUTION OF THE AGENCY PROVIDING FUR TIE ISSUANCF OF ENERGY A.ND IRESOURCE DEVTLOPMIENT IREVENUE BONDS TO BE PAID INTO ANY SPECIAI FLNDS FROAI THE PROCEEDS OF SUCH BONDS AND TIIE FINANCING OF 'THE PLACING OF SUCH FACILITY IN OPERATION. ANY OIBLIGATION, COST, OI EXPENSE INCURRED AFTER TIHE EFFECTI'E DATE OF TIIIS SECTION BY ANY GOVERNMENTAL AGENCY OR PERSON FOR SUIVTYS. BORINGS, PREPARATION OF PLANS AND SPECIFICATIONS, AND OTHER ENGINEERING SERVICES, OR ANY OTHER COST DESCRIBED ABOVE, IN CONNECTION IVITII THE ACQUISITION OR CONSTRUCTION OF A FACILITY MAY BE REGARDED AS A PART OF THE COST OF SUCII FACILITY AND NAY BE REIMBURSED OUT OF THE PROCEEDS OF ENERGY AND DEVELOPIIENT REVENUE BONDS.

(D) "OWNER" INCLUDES ANY PERSON HAVING ANY TITLE OR INTEREST IN ANY PROPERTY, RIGHTS, ESTATES, EASEMENTS, OR INTERESTS AUTHORIZED TO BE ACQUIRED.

(E) "REVENUES" MEANS ALL RENTALS AND OTHER CHARGES RECEIVED BY THE AGENCY FOR THE USE OR SERVICES OF ANY ENERGY AND RESOCRCE DEVELOPMENT FACILITY, ANY CONTRACT, GIFT, OR GRANT RECEIVED WITH RESPECT TO ANY ENERGY AND RESOURCE DEVELOPMENT FACILITY, AND MONEYS RECEIVED WTTH RESPECT TO THE LEASE, SUBLEASE, SALE, INCLUDING INSTALLIIENT SALE OR CONDITIONAL SALE, OR OTHER DISPOSITION OF AN ENERGY ANID RESOURCE DEVELOPMENT FACILITY, MIONEYS RECEITED IN REPAYMENT OF AND FOR INTEREST ON ANY I,OANS MADE BY THE AGENCY TO A PERSON OR GOVERNMENTAL AGENCY. WHETHER FROII THE UNITED STATES OR ANY DEPARTIENT, ADMINISTRATION, OR ACENCY 'TIEREOF, OR OTHERITSE, PROCEEDS OF ENERGY ANI RESOURCE DEVELOPMENT REVENUF BONDS TO THE ENTENT THAT THE CSE TIIEREOF FOR PAYMENT OF PRINCIPAL OF, PREMIUNI, IF ANY, OR INTEREST ON THE BONDS IS AUTIIOIIZED BY TIIE AGENCY, PROCELDS FROM ANT INSURANCE, CONDEMNATION, OR GUARANTY PLNTAINING TO A FACILITY OR PROPERTY IORTGAGED TO SECURE RONDS OI PERTAINING TO THE FINANCING OF A FACILITY, AND INCONE AND PROFIT FROM THE INLESTIENT OF 'TIIE PROCEEDS OF ENERCYY AND RESOURCE DEVELOPIENT REVENUE BONDS OR OF ANY REVENUES. 
(F) "PUPLIC ROADS" INCLUDES ALL PUBLIC IITGHWAYS, ROADS, AND STREYTS IN TIIE STATE, WHETIIER MAINTAINED BY THIE STATE, COUNTY, CITY, TOWNSIIIP, OR OTHER I'OLITICAL SULIIVISION.

(G) "CONSTRUCTION" UNIESS THE CONTEXT INDICATES A DIFFERINT MEANIVG OR INTENT, INCLUDES CONSTRUCTION, RECONSTISUCTION, ENLARGEMENT, IMPROVEMENT, OR PIOVIDING FURNISHINGS OR EQUIPMENT.

(H) "ENERGY AND RESOURCE DEVELOPMENT REVENUE BONDS," UNLESS THE CONTEXT INDICATES A DIFFERENT MEANING OR INTENT, INCLUDES ERERGY AND RESOURCE DEVELOPMENT REVENUE BONDS, ENERGY AND RESOURCE DEVELOPIIENT FEVENUE NOTES, AND ENERGY AND RESOURCE DEVELOPMENT REVENUE REFUNDING BONDS.

(I) "PERSON" MEANS ANY INDIVIDUAL, FIRM, PARTNERSHIP, ASSOCIATION, OR CORPORATION.

(J) AS LSED IN SECTIONS 122.84 TO 122.87 OF THE REVISED CODE. "ENERGY" MEANS CRUDE OIL, RESIDUAL FUEL OIL, REFINED PITROLEUM PRODUCTS, COAL, NATURAL AND ARTIFICIAL GAS, PROPANE, AND ELECTRICITY.

Sec. 122.64. (A) There is hereby created the Ohio ENERGY AND RESOURCE development AGENCY, A BODY BOTH CORPORATE AND POLITIC OF THE STATE, herein referred to as the "AGENCY." The PURPOSES of the eenter AGENCY shall be to encourage, promote, and support new technological, economic, and organizational research, EXPERIMENTAL AND DENONSTRATION projects, and programs designed to MORE EFFICIENTLI UTILIZE PRESENT, NEW, OR ALTERNATIVE ENERGY OR OTHER RESOURCES, TO ASSIST IN THE FINANCING OF ENERGY AND RESOURCE DEVELOPMENT FACILITIES, TO improve the general weltare of the people of the state to foster economic derelopment and the creation OR PRESERIATION of jobs and employment opportunities within the state. AND TO ASSIST AND COOPERATE WITH GOVERNMENTAL AGENCIES IN ACHIEVING THESE PURPOSES. THE AGENCY SHAIL GIVE PRIOIITY TO THE ESTABLISHMIENT, LOCATION, AND CONSTRUCTION OF ONE LOW HEAT VALUE AND ONE HIGH HEAT VALUE COAL CONVERSION PLANT, AT SUITABLE SITES WITHIY TIIIS STATE. To achieve AHESE I'URPOSES the AGENCY MAY:

(1) Identify, plan, organize. initiate. and SPONSOR STUDIES, RESEAICH. AND EXPERIMIEN. TAL AND DEIIONSTIATION FACIIITIES AND PROJECTS WHICH WOULD I.EAD TO TIIE INEIELOPMLNT AND MIORE EFFICIENT UTII.IZATION OF PRESENT, NEIT, OR ALTEINATIVE ENERGY SUURCES IN THE STATE, TO THE CONSERVA- 
TION OF ENERGY, TO TIIE ATTRACTION OF FEDERAL AND OTIIER DEV'I.OIMENT FUNDING in emergingr and estallished national or state piciority areas witint

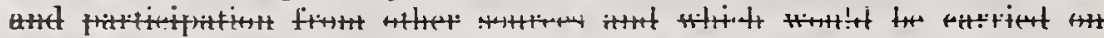
OHE OIR TO TIE ENHANCEMENT OF THE ECONOMIC DEVELOI'MLNT OF TIIE STATE;

(2) SEEK OUT AND DEVEIOP proposals out federal ENERGY AND OTIEI development proms which fitt public and private, to carry forward - wttrifte tt: terter, those PURPOSES set forth in Hirisity $(1+$ of this section;

(3) Promote, assist, and provide financial assistance for the development of nonprofit corporations organized and established under Chapter 1702. of the Revised Code to

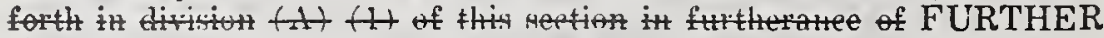
the PUIRPOSES of this section;

(4) APPLY FOR, RECEIVE, AND ACCEPT GRANTS, GIFTS, CONTRIBUTIONS, LOANS, AND OTHER ASSISTANCE IN ANY FORM FROM PUBLIC AND PRIVATE SOURCES. INCLUDING ASSISTANCE FROM ANY GOVERNMENT AGENCY;

(5) MAKE GRANTS FROM FUNDS THAT ARE APPROPRIATED BY THE GENERAL ASSEMBLY AND FROM GIFTS OR GRANTS OBTAINED UNDER DIVISION (A) (4) OF THIS SECTION TO PERSONS, BOARDS OF EDUCA'NON, STATE AGENCIES, OR POLITICAL SUBDIVISIONS FOR THE PURPOSES OF CUNSTRUCTING AND OPERATING EXPERIMENTAL AND DEMONSTRATION FACILITIES WHICH DEVELOP, TEST, OR DEMONSTRATE MORE EFFICIENT AND ENVIRONMENTALLY ACCEPTARLE METHODS OF EXTRAC'TING ENERGY RESOURCES, NEW CONCEPTS OR TECHNOLOGY FOR THE CONSER VATION OF ENERGY, NEW CONCEPTS OR TECHNOLOGY FOR THE EFFICIENT AND ENVIRONMENTALLY ACCEPT ABLE UTILIZATION OF PRESE.NT. NEW. OR ALTERNATIVE ENERGY SOURCES, OR CONCEPTS OR TECHNOLOGY WHICH DEVELOP RESOURCES OF THE STATE. GRANTS MAY BE MADE FOR. BLT NOT LIMIITED TO, PROJE.CTS SUCH AS: EXPERIMENTAL DEMONSTRATIONS OF THE LSE OF OHIO (OAL IN PROCESSES WHICH WOULD FACILITATE ITS WIDESPREAD USE AS A SOURCE OF ENERGY: EXPERIMENTAL DEMINNSTATIOAS OF NEW OR IMPROIED COAL, NATURAL GAS. AND NATLRAL PETROLEUM EXTRACTION TECHNIQUES AND OF RECLAMIATION TECHNIQUES AT THE EXTRACTION SITES : EXPERIMENTAL DEMONSTRATIONS OF SOLAR HEATING AND COOIING AND POTENTIALLY ENERGY-EFFICIENT CONSTRUCTION IN PUBLIC BUILDINGS, SCHOOLS, OFFICES, COMIERCIAL ESTABLISHAIENTS, AND IESIINENTAL HOMIES: EIPERIMIENTAL DEMONSTRATIONS OF TIIE UTILIZATION OF WASTE PRO- 
DUCTS IN ENERGY PRODUCTION AND MINERAL AND ENERGY CONSERVATION; AND EXPERIMENTAL DEMONSTRATIONS OF' TPCHNOIOGIES WHICH WOULD PERMIT UTILITY PRICING POLICIES WIIICII MAY REDUCE THE CONSUMER COSTS OF INNERGY ;

(6) INTTIATE, ACQUIIE, CONSTRUCT, MAINTAIN, REPAIR, AND OPERATE ENEIIGY AND RESOURCE DEVELOPMENT FACILITIES OR CAUSE TIIE SAME TO BE OPERATED PURSUANT TO A LEASE, SUBLIASE, OR AGREEMENT WITH ANY PERSON OR GOVERNMENTAL AGENCY;

(7) MAKE LOANS AND GRANTS TO GOVERNMENTAL AGENCIES FOR THE ACQUISITION OR CONSTRUCTION OF ENERGY AND RESOUPCE DEVELOPMENT FACILITIES BY SUCH GOVERNIIENTAL AGENCIES;

(8) MAKE LOANS TO PERSONS FOR THE ACQUISITION OR CONSTRUCTION OF ENERGY AND RESOURCE DEVELOPMENT FACILITIES BY SUCH PERSONS;

(9) ISSUE ENERGY AND RESOURCE DEVELOPMENT REVENUE BONDS OF THIS STATE PAYABLE SOLELY FROM REVENUES, TO PAY THE COST OF ENERGY AND RESOURCE DEVELOPMENT FACILITIES ;

(10) ENTER AGREEMENTS WTTH PERSONS AND GOVERNMIENTAL AGENCIES, IN ANY COMBINATION, FOR THE PURPOSES OF THIS SECTION.

(B) The AGENCY shall be under the control, management, supervision, and direction of the board of trustees of the Ohio ENERGY AND RESOURCE derelopment AGENCY, which shall be composed of nine members. The members of the boald shall be the

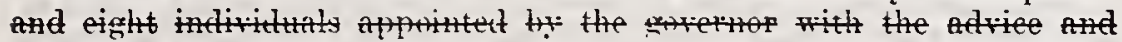

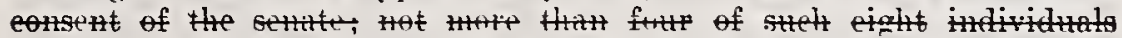

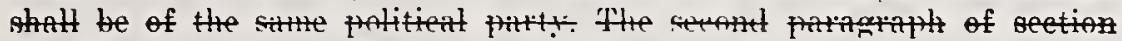

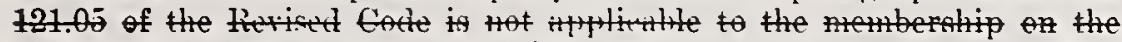

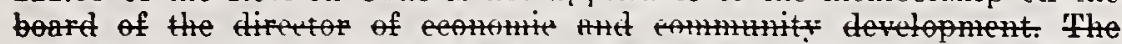

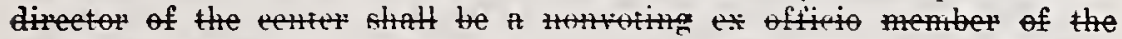

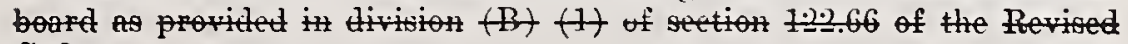
Gode.

(G) Fithint thinty thits of the efferive the of this the

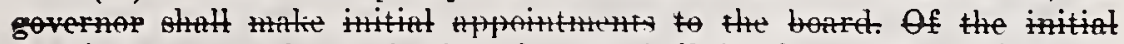

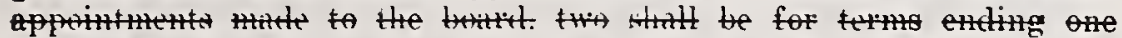

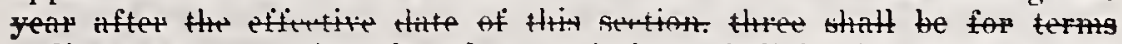

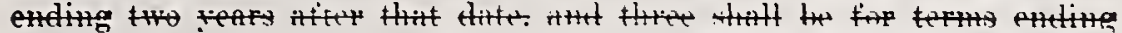

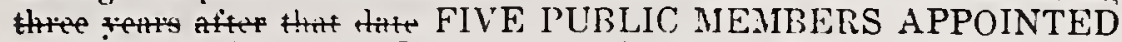
BY THE GOVERNOR WITI TIIE ADYICE AND CONSENT OF THE SENATE. NO MORE THAN TIIREE OF WIIOM SHALL BE OF THE SAME POLITICAI PARTY AND FOUR I,EGISLATIVE MEMBERS, ONE OH WHOM SHALI, BE APPOINTED BY THE PRESIDENT PRO TIIIPORE OF' TIIE SENATE, ONE OF WHOM SHALL BE APPOINTLD BY THE MINORITY LEADER OF THE 
SENATE, ONE OF WHOM SHALI, PE APPOINTED BY THE SPEATFR OF" "THE IIOUSE, AND ONL OF WIIOM SHALI, ISE APPOINTED BY THE MINOIITY LEAIIER OF TIIE HIOUSE. EACII LEGISLATIVE LAADER SHAI.I, DISIGNATE ANOTIIER MEMHER OF THE GENERAL ASSEJIBLY WIO IS OF TIE APPOINTED MEMBER'S SAML HOLSE ANI POLITICAL PARTY TO SERVE AS 'TIE AIPOINTED MEIIBER'S ALTERNATE AT ALL MEETINGS OF' THE BOAIID 'THAT TIIE APPOINTED MEMBEI IS UNABLE TO ATTEND. THE LEGISLATIVE MEMBERS AND THEIR DESIGNATED ALTERNATES SHALL BE ENTITLED TO FUI. PAPTICIPATION IN ALL BOARD DELIBERATIONS AND ACTIVITIES, EXCEPT THAT THEY SHALL SERVE AS NONVOTING MIEMBERS. EACH LEGISLATIVE MEMBER SHALL SERIE ON THE BOARD FOR THE DURATION OF THE ELECTED TERM THAT HE IS SERVING AT THE TIME OF HIS APPOINTIENT. WITHIN THIRTY DAYS OF THE EFFECTIVE DATE OF THIS ACT THE GOVERNOR SHALL MAIEE INITIAL APPOINTMENTS TO THE BOARD. OF TIE INITIAL APPOINTMENTS MADE TO THE BOARD, ONE SHALL BE FOR A TERII ENDING ONE YEAR AFTER THE EFFECTIVE DATE OF THIS SECTION, ONE SHALL BE FOR A TERM ENDING THO IEARS AFTEP THAT EFFECTIVE DATE, ONE SHALL BE FOR A TERM ENDING THREE YEARS AITER THAT EFFECTIVE DATE, AND TWO SHALL BE FOR TERMIS ENDING FOUR YEARS AFTER THAT DATE. Thereafter, PUBLIC members' terms of office shall be for thee FOUR years, each term ending on the same day of the same month of the year as did tne term wiich it succeeds. Each PUBLIC member shall hold ofice from the date of his appointment until the end of the term for which he was appointed. Any PUBLIC member shall continue in office subsequent to the expiration date of his term until his successor takes office, or until a period of sixty days has elapsed, whichever occurs first. Any - member of the board shall be eligible for reappointment.

(D) Each PUBLIC member of the board shall be a resident of the state and a qualified elector therein. Befole entering upon the discharge of his duties, each of the board shall take an oath as prescribed by SECTION 7 of Article XV, Ohio Constitution.

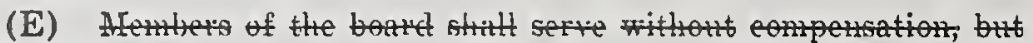

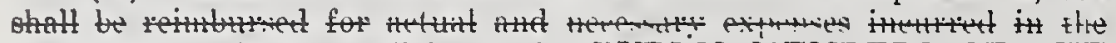

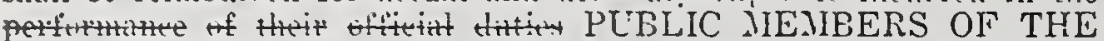
BOARD, WHEN ENGAGED IN THEIR DUTIES AS MEMIBERS OF THE BOARD, SHALL BE PAID AT THE PER DIEM RATE OF STEP 1, PAY RANGE 32, UNDER SCHEILILE B OF SECTION 124.15 OF TIE REVISED CODE, OR AS OTHERIVISE PROTIDED BY LAW, AND SIIALL RECEITE TIIEIR NECLSSARY TRAVELING EXPENSES. SLCH PAIIIENTS FOR PUBLIC MEMBERS OF THE BOARI) SHALL BE MADE FROM TIIA MONEYS APIROPRIATED FOR OPERATING EXPENSES OF 


\section{A-ENGROSSED House Bill 2036}

Ordered by the Senate April 18

(Including Amendments by House March 6 and by Senate April 18)

By order of the Speaker (at the request of the Joint

Interim Committee on Environmental/Agricultural and Natural Resources)

\section{SUMMARY}

The following summary is not prepared by the sponsors of the measure and is not a part of the body thereof subject to consideration by the Legislative Assembly. It is an editor's briel statement of the essential features of the measure.

Adds solar energy consideration to comprehensive planning; allows county planning commission to recommend ordinances protecting and assuring access to incident solar energy and governing height and setback of buildings; allows city planning commission to recommend zoning ordinances limiting or conditionally limiting aspects of buildings and to recommend energy saving incentives. Permits city council to consider solar energy potential in regulating buildings and open spaces. Requires council to exercise powers so as to preserve constitutional rights.

NOTE: Matter In bold face in an amended section Is new; matter [italic and bracketed] is existing law to be omitted; complete new sections begin with BECTION. 
2 Relating to planning and zoning; amending ORS 215.055, 215.110, 227.090

8 and 227.230 .

1 Be It Enacted by the People of the State of Oregon:

6. Section 1. ORS 215.055 is amended to read:

- 215.055. (1) Any comprehensive plan and all zoring, subdivision or 7 other ordinances and regulations authorized by ORS 215.010 to 215.233 8 and 215.402 to 215.422 and adopted prior to the expiration of one year - following the date of the approval of state-wide planning goals and 20 guidelines under ORS 197.240 shall be designed to promote the public 11 health, safety and general welfare and shall be based on the following 12 considerations, among others: The various characteristics of the various 13 areas in the county, the suitability of the areas for particular land uses 14 and improvements, the land uses and improvements in the areas, trends 15 in land improvement, density of development, property values, the needs 16 of economic enterprises in the future development of the areas, needed 17 access to particular sites in the areas, natural resources, including inci18 dent solar energy and utilization, of the county and prospective needs for 19 development and utilization thereof, and the public need for healthful, 20 safe, aesthetic surroundings and conditions.

21 (2) Any plan and all zoning, subdivision or other ordinances and reg22 ulations authorized by ORS 215.010 to 215.233 and 215.402 to 215.422 and 23 adopted after the expiration of one year after the date of the approval 21 of state-wide planning goals and guidelines under ORS 197.240 shall be 25 designed to comply with such state-wide planning goals and any subse 26 quent revisions or amendments thereof.

27 (3) In order to conserve natural resources of the state, any land use 28 plan or zoning, subdivision or other ordinance adopted by a county shall 29 take into consideration lands that are, can or should be utilized for sources 80 or processing of mineral aggregates.

31 Section 2. ORS 215.110 is amended to read:

32 215.110. (1) The commission may recommend to the governing body 83 ordinances intended to carry out part or all of the comprehensive plan 
1 adopted by the commission. The ordinances may provide, among other

2 things, for:

3 (a) Zoning,

1 (b) Official maps showing the location and dimensions of, and the

6 degrce of permitted access to, existing and proposed thoroughfares, ease-

6 ments and property needed for public purposes,

7 (c) Preservation of the integrity of the maps by controls over con8 struction, by making official maps parts of county deed records, and by 9 other action not violative of private property rights, and

10 (d) Conservation of the natural resources of the county.

11 (2) The commission may also recommend to the county governing 12 body ordinances renaming public thoroughfares, protecting and assuring 18 access to incident solar energy, numbering property, and controlling sub14 division and other partitioning of land and the location, construction, main15 tenance, repair and alteration of buildings, including height and setback, 16 and other structures.

17 (3) The governing body may enact, amend or repeal ordinances rec18 ommended by authority of this section, together with whatever amend19 ments it believes the public interest requires. The governing body may 20 also enact, amend or repeal with reference to any subject mentioned in 21 subsection (1) of this section, an ordinance on which the governing body 22 Initiates action, provided that it first requests from the commission a re23 port and recommendation regarding the ordinance and allows reason24 able time for submission of the report and recommendation. The gov26 erning body may also enact, amend or repeal with reference to any sub26 ject mentioned in subsection (2) of this section, an ordinance on which 27 the governing body initiates action, regardless of whether the county 28 has a planning commission; provided that, in the event the county has 29 a planning commission, the governing body first requests from the com30 mission a report and recommendation regarding the ordinance and al31 lows a reasonable time for submission of the report and recommendation.

(4) The governing body may refer to the legal voters of the county 
1 for their approval or rejection an ordinance or amendinents thereto for 2 which subsection (3) of this section provides. If only a part of the county 3 is affected, the ordinance or amendment may be referred to that part only.

4 (5) An ordinance enacted by authority of this section may prescribe 6 fees and appeal procedures necessary or convenient for carrying out the 6 purposes of the ordinance.

7 (6) No retroactive ordinance shall be enacted under the provisions of 8 this section.

9 Section 3. ORS 227.050 is amended to read:

10 227.090. Except as otherwise provided by law, the commission may:

11 (1) Recommend and make suggestions to the city council and to all 12 other public authorities concerning laying out, widening, extending, park13 ing and locating of streets, sidewalks and boulevards, rellef of traffic 11 congestion, betterment of housing and sanitation conditions and estab15 lishment [of zones of districts limiting] of zoning ordinances limiting 16 the use, height, area and bulk of buildings and structures.

(2) Recommend to the city council and all other public autisorities 18 plans for regulation of the future growth, development and beautifica19 tion of the inunicipality in respect to its public and private buildings and 20 works, strcets, parks, grounds, and vacant lots, and plans consistent with 21 future growth and development of the city in order to secure to the city 22 and its inhabitants sanitation, proper service of all public utilities, includ23 ing appropriate public incentives for overall snergy conservation and 24 harbor, shipping and transportation facilities.

25 (3) Recommend to the city council and all other public authorities 26 plans for prornotion, development and regulation of industrial and eco27 nomic nceds of the community in respect to private and public enterprises 28 engaged in industrial pursuits.

29 (4) Advertise the industrial advantages and opportunities of the 30 municipality and availability of real estate within the municipality for 31 industrial settlement.

32 (5) Encourage industrial settlement within the municipality.

33 (6) Make an economic survey of present and potential possibilities of 31 the municipality with a view to ascertaining its industrial needs. 
1 (7) Study needs of existing local industries with a view to strength-

2 ening and developing local industries and stabilizing employment con3 ditions.

4 (8) Do and perform all other acts and things necessary or proper to 5 carry out the provisions of ORS 227.010 to 227.180 .

6 (9) Study and propose in general such measures as may be advisable 7 for promotion of the public interest, health, morals, safety, comfort, con8 venience and welfare of the city and of the area six miles adjacent thereto

9. Section 4. ORS 227.230 is amended to read:

10227.230 . (1) The council may by ordinance regulate, restrict and seg11 regate the location of industries, the several classes of business, trades 12 or callings, the location of apartment or tenement houses, clubhouses, 13 group residences, two family dwellings, single family dwellings and the 11 several classes of public and semipublic buildings, and the location of 15 buildings or property for specified uses, and may divide the city into dis16 tricts of such number, shape and area as the council may deem best suited 17 to carry out the purposes of ORS 227.220 to 227.280 , subject to the provi18 sions of ORS 227.250 and 227.260 .

19 (2) The council may place reasonable regulations and limitations up20 on the height, setback and bulk of buildings erected after May 29, 1919, 21 and regulate and determine the area of yards, courts and other open 22 spaces having due regard of the use and occupancy of the land and may 23 also consider the site slope and tree cover, with regard to solar exposure 24 in such case. The council shall not unreasonably restrict construction where 25 site slope and trce cover make incident solar energy collection unfeasible, 26 except an existing solar structure's sun plane shall not be substantially 27 impaired.

28 (3) In order to conserve natural resources of the state and the pros29 pective needs for development thereof, any land use zoning ordinance 30 adopted by a city shall take into consideration lands that are, can or 31 should be utilized for sources or processing of mineral aggregates.

32 (4) The powers given in this section shall be so exercised as to preserve 83 constitutional rights. 


\section{A-ENGROSSED House Bill 2202}

Ordered by the Speaker May 9 (Including Amendments by House May 9)

Sponsored by Representatives PAULUS, BUNN, FROHNMAYER, GUSTAFSON, Senators CARSON, HALLOCK, WINGARD, Representatives BURROWS, DENSMORE, FADELEY. KATZ, MARTIN, STEVENSON, VAN VLIE'T, WOLFER, Senators HEARD, RIPPER

\section{SUMIMARY}

The following summary is not prepared by the sponsors of the measure and is not a part of the body thcreot subject to consideration by the Legislative Assembly. It is an editor's brief statement of the essential fealures of the measure.

Exempts from ad valorem taxation increased value of [residential property] any building or structure attributable to solar energy heating or cooling system, or any other solar energy system not fossil-fueled, excluding heat pumps .

Applies to assessment years beginning on and after January 1, 1976, but not to assessment years beginning on or after January 1,1986 .

NOTE: Matter in bold tace in an amended sectlon is new; matter [italic and bracketed] is existing law to be omitted; complete new sections begin with BECTION. 
2 helating to ad valorem taxation.

a Be It Enacted by the Pcople of the State of Oregon:

1 SECTION 1. Any building or structure equipped with a solar energy 6 heating or cooling system, or with any other solar energy system that is not 6 fossil-fueled, is exempt from ad valorem taxation in an amount that 7 equals any positive amount obtained by subtracting the true cash value 8 of the property without the solar energy system from the true cash value 9 of the property with the system. As used in this section, the term "solar 10 energy system" does not include heat pumps.

11 SECTION 2. This Act applies to assessment years beginning on or 12 after January 1, 1976 but shall not apply to assessment years beginning on 13 or after January 1, 1986. 


\section{SENATE AMENIMINTS TO PIRIN'TEI) A-EN(GROSSEL) HOUSE BILL 2202}

\section{By COMMITTEE ON REVENUE}

May 29

1 On page 1 of the printed A-engrossed bill, delete the sponsors and insert

2 "Committee on Rev'enue".

3 On page 2, delete lines 4 through 13 and insert:

- "SECTION 1. Property equipped with a solar energy heating or eooling 6 system is exempt from ad valorem taxation in an amount that equals any 6 positive amount obtained by subtracting the true cash value of the property 7 as if it had a conventional heating or cooling system from the true cash 8 value of the property with the solar heating or cooling system.

9 "SECTION 2. This Aet applies to assessment years beginning on or 10 after January 1,1976 , but prior to January 1, 1986.". 


\section{CHAPTER 111}

(S.B. 283)

\section{ALLOWING TAX DEDLCTIONS FOR SOLAR ENERGY SYSTEMS}

\section{An Act}

ENTITLED, An Ait to provide for a property tax deduction for the utilization of solar energy systems.

BE IT ENACTED BY TIIE LEGISLATURE OF TIIE STATE OF SOUTH DAKOTA:

Section 1. Fur the purpose of this Act, solar heating, solar hot water, or solar cooling devices shall include all controls, tanks, pumps, heat exchangers, and other hardware necessary to effect the installation of a solar heating or cooling system.

Section 2. The owner of real property who attaches solar heating or cooling devices to or a part of any residential improvement used primarily for residential purposes may have deducted annually from the assessed valuation of real property a sum which is enual to the lesser of:

(1) The remainder of the assessed valuation of the real property with the solar heiting or cooting system included, minus the valuation of the real property without the system, or

(2) Two thousind dollars.

Section 3. The owner of real property emploving a solar energy system of heiting or cooling who desires to tuim the deduction provided in section 1 of this Ait shall file a certified statement in duplication with the auditor of the county in which the real property is locilted. In addition, 1:1 unate sibll tile the statement on forms prescribed hy the department 11 ibsuls, and the owner shall file the statement between November 1

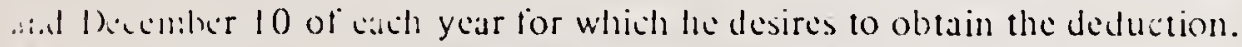
1 pun cierification of the statement by the assessor of the county in which whe real property is locited, the auditor stabll make the deduction.

Siction 4. This dit shall expire July 1, 1980.

Approved Mariti 25, 1975. 
H.B. No. 546

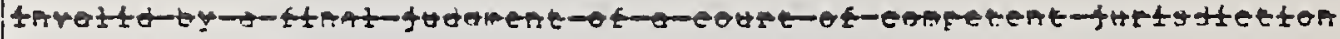

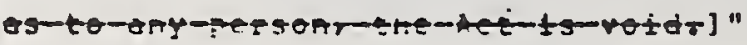

Sec. 2. This Article takes effect January 1, 1976. ARTICLE XXI.

Section 1. Article 20.04, Tltle 122A. Taxation-General. Revised Clv1l statutes of Texas, 1925, as amended, is amended hy adding a section (CC) to read as follows:

"(CC) There are exempted from the taxes 1mposed by this Chapter the recelnts from the sale, lease or rental of, and the stcrage, use, or other consumption in this state of solar energy devices. A 'solar energy device' is a system or series of mechanisms designed frimar11y to provide heating or cooling or to produce electrical or mechanical power or both by means of collecting and transferring solar-generated eneray and includes mechanical or chemical cevices having the capacity for storlin solar-generated energy for use in heating or cooling or in the Froduction of povier."

Sec. 2. Article 12.01, T1tle 122A, Taxat1on--General, Revised C1v11 statutes of Texas, 1925, as amended, is amended bv adding a section (6) to rear as follows:

"(6) A corforation may deduct from its taxable capital taxable in this state the amortized cost of a solar energy device acquires by the corporation for the production of energy or for heating or cooling and used In this state by the corporation. The cost may he amortized for any period not less than fo months in equal monthly amounts beglnnina on the month the device is 
H.A. No. 546

placed into service in this stace and extendina only during the perloj trat the device is in use in this state. A corporation maring a deduction under this section shall flle with the Corptroller an amortization schedule showlna the perloo durlng which a deduction 15 to be made and on the request of the Comptroller shall provite proof of the cost of the device and of Its operation in this state. A separate deduction may be taken for each device placed in service in this state by the corporation."

Article XXII.

Section 1. Section $(H)$, Article 20.04, Tltle 122A,

"(H) United states: State; Pol1tical Subdivision; Rellalous.

"(1) The Uniter States, 1 ts urincorporated agencles and Instrunenta11t1es.

"(2) iny incornorated aqency or instrumentaldty of the (indted states wholly onned by the united states or by a corporation Wholly oined by the Unlted states.

"(3) The state of Texas, Its unincorporated aqencles and instrumentalitios.

"(4) Any cointy, c1tv, soecial district or other polltical 


\section{CHAPTER}

\section{$3: 31$}

An Ait to aniend the Code of Virginin by adding a section numbered 9.6 .5 .21 , relating to the criation of a so! 2 energy center in the Science Miseum of Virininia.

[H 1809]

\section{Approved MAR 181975}

[3" it cnacted by the General Assembly of Virginia:

1 lliat the code of Virginia is amended by adding a section mumbured !)-(65.2:1 as follows:

$\$$ \$ ti, 2.1. Sollar energy center. - The Virginia Solar Energy Center is hereby created snd cinsurutid as part of the Museum. The purposes of the Center are: (i) to serve the prople of the Commonwealth as a clearinghuuse to gather, maintain and disseminate A'rncral and technical information on solar energy and its utilization: (ii) to coordinate programs for solar energy data-gathering in Virginia; (iii) to cuordinate efforts and programs on solar enermy with other State agencies and institutions. other states and federal akencies; (iv) to promote cooperation among and between lirginia business, industry, agriculture and the public related to the use of solar energy: (v) to develop public education programs on solar energy for use in schools and by the public, and: (vi) to provide assistance in formulating policies on the utlization of solar energy that would be in the best interest of the Commonwealth.

The intent of the General Assembly is to provide an organization for the purposes set out in this act and receive non-State funds for such purposes.

President of the Senate

Speaker of the llouse of Delegates

Approved:

\section{Governor}




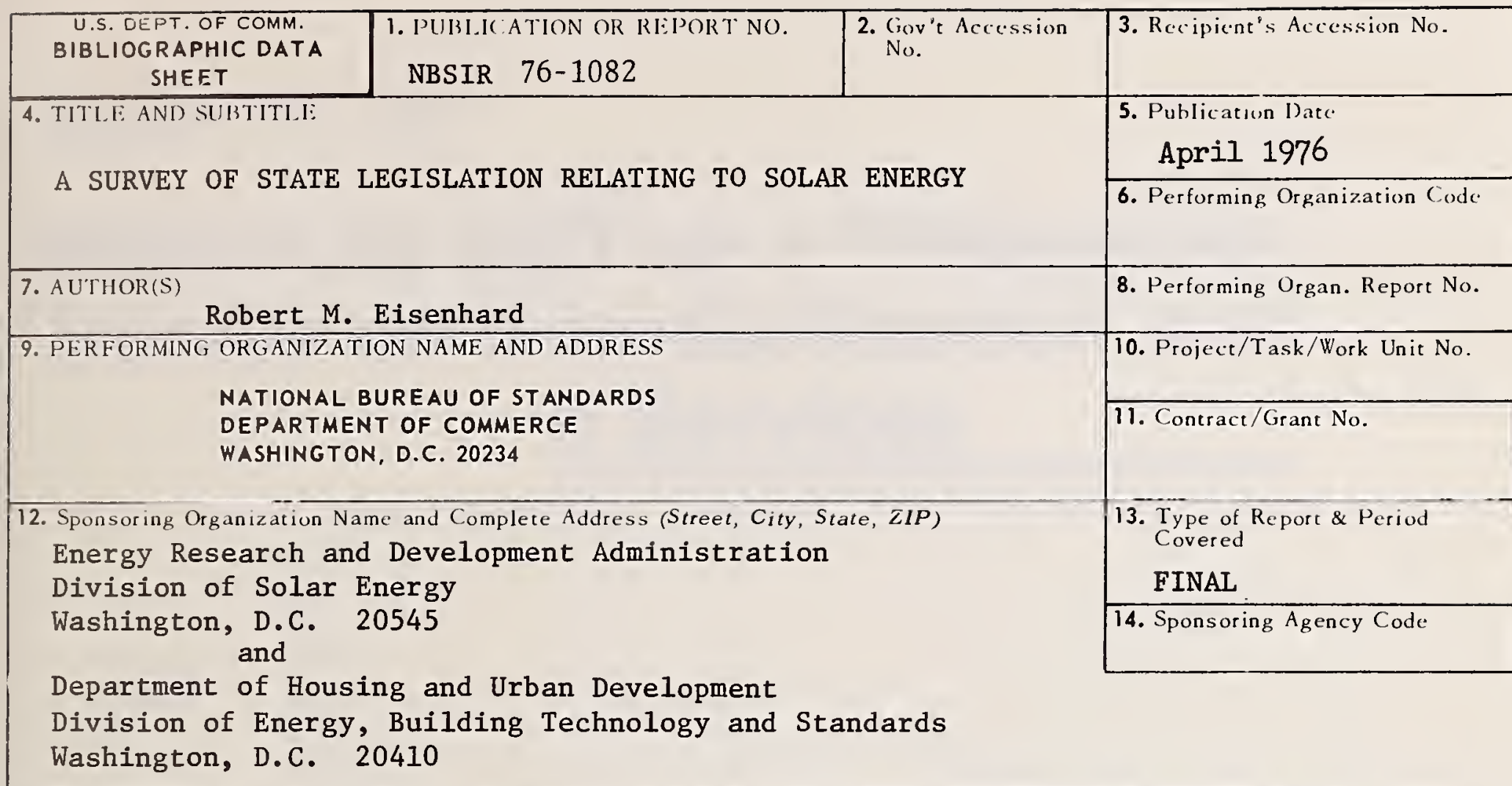

16. ABSTRACT (A 200-word or less factual summary of most significant information. If document includes a significant bibliography or literature survey, mention it here.)

This report reviews enacted State legislation dealing with solar energy. Acts involving tax incentives, reduced property assessments, research and development, solar easements and solar energy promotion are identified and abstracted. The responsible State agency and official are listed. Acts and supporting forms and other information are included as appendices.

17. KEY WORDS (six to twelve entries; alphabetical order; capitalize only the first letter of the first key word unless a proper name; separated by semicolons)

Architecture; buildings; design; energy; legislation; solar; State

18. AVAILABILITY $\overline{\mathrm{X} \text { Unlimited }}$

For Official Distribution. Do Not Release to NTIS

Order From Sup. of Doc., U.S. Government Printing Office Washington, D.C. 20402, SD Cat. No. C13

X Order From National Technical Information Service (NTIS) Springfield, Virginia 22151

\begin{tabular}{|l|c|}
\hline $\begin{array}{l}\text { 19. SECURITY CLASS } \\
\text { (THIS REPURT) }\end{array}$ & 21. NO. OF PAGES \\
UNCLASSIFIED & 166 \\
\hline $\begin{array}{l}\text { 20. SECURITY CLASS } \\
\text { (THIS PAGE) } \\
\text { UNCLASSIFIED }\end{array}$ & 22. Price \\
$\$ 4.50$ \\
\hline
\end{tabular}


